Prepared in cooperation with Mohave County and the City of Kingman

\title{
Assessing Potential Groundwater-Level Declines from Future Withdrawals in the Hualapai Valley, Northwestern Arizona
}
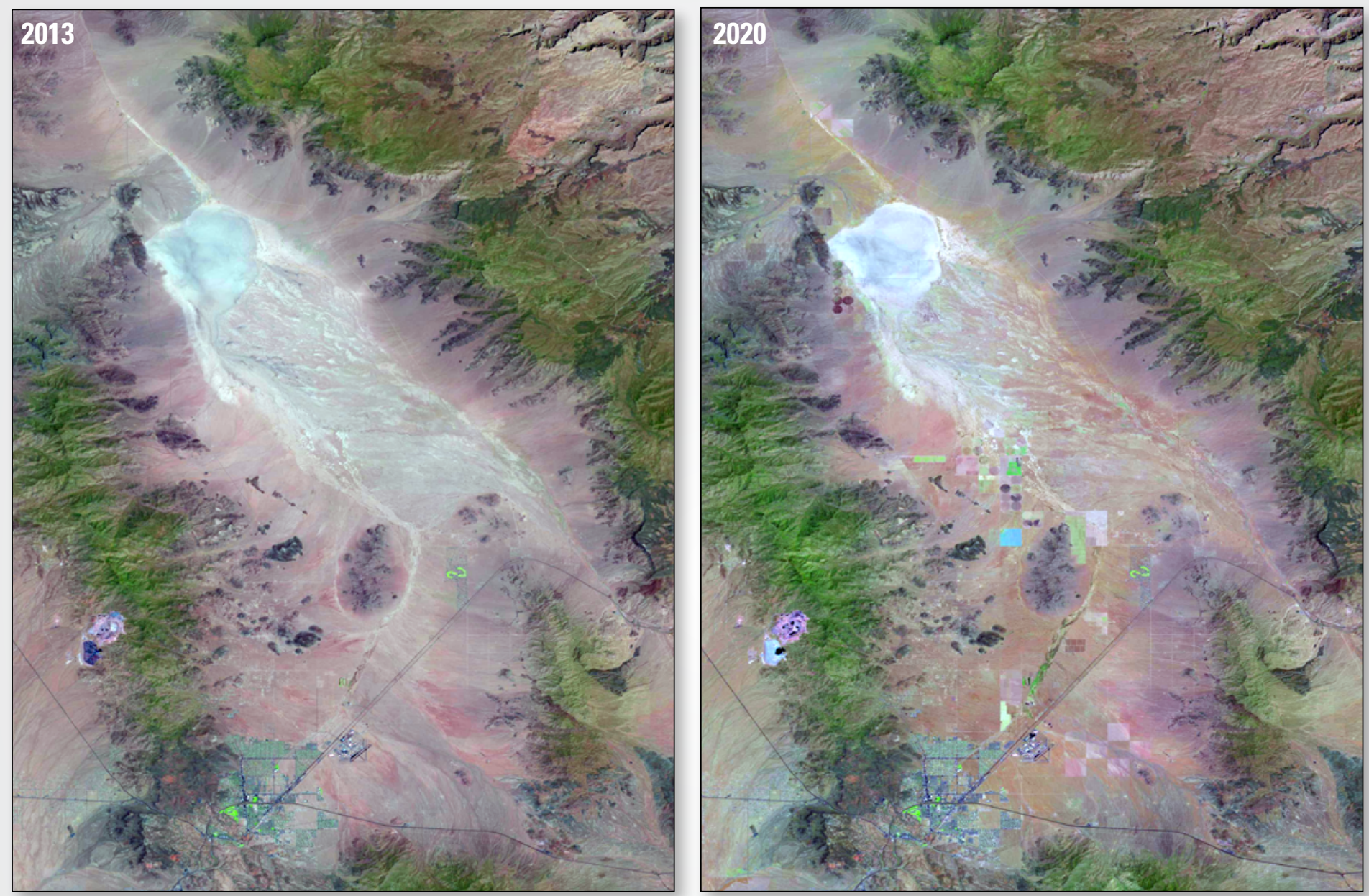

Scientific Investigations Report 2021-5077

U.S. Department of the Interior U.S. Geological Survey 
Cover. Satellite images showing land cover change between May of 2013 (left) and May of 2020 (right). Images are from LandLook Viewer, U.S. Geological Survey. Images are "Natuaral Color" using bands 6, 5 , and 4 of the Landsat Operational Land Imager. Backdrop photograph shows an irrigation structure in Hualapai Valley. U.S. Geological Survey photograph taken on February 20, 2018, from Stockton Hill Road looking east across Hualapai Valley. 


\section{Assessing Potential Groundwater-Level Declines from Future Withdrawals in the Hualapai Valley, Northwestern Arizona}

By Jacob E. Knight, Bruce Gungle, and Jeffrey R. Kennedy

Prepared in cooperation with Mohave County and the City of Kingman

Scientific Investigations Report 2021-5077 


\section{U.S. Geological Survey, Reston, Virginia: 2021}

For more information on the USGS - the Federal source for science about the Earth, its natural and living resources, natural hazards, and the environment-visit https://www.usgs.gov or call 1-888-ASK-USGS (1-888-275-8747).

For an overview of USGS information products, including maps, imagery, and publications, visit https://store.usgs.gov.

Any use of trade, firm, or product names is for descriptive purposes only and does not imply endorsement by the U.S. Government.

Although this information product, for the most part, is in the public domain, it also may contain copyrighted materials as noted in the text. Permission to reproduce copyrighted items must be secured from the copyright owner.

Suggested citation:

Knight, J.E., Gungle, B., and Kennedy, J.R., 2021, Assessing potential groundwater-level declines from future withdrawals in the Hualapai Valley, northwestern Arizona: U.S. Geological Survey Scientific Investigations Report, 63 p., https://doi.org/10.3133/sir20215077.

Associated data for this publication.

Knight, J.E., 2021, Data release for transient groundwater model of the Hualapai Valley Groundwater Basin, Mohave County, Arizona: U.S. Geological Survey data release, https://doi.org/10.5066/P9017DI9.

ISSN 2328-0328 (online) 


\section{Contents}

Abstract

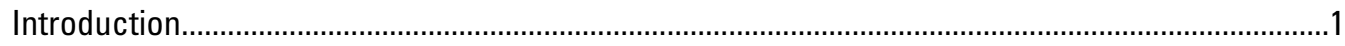

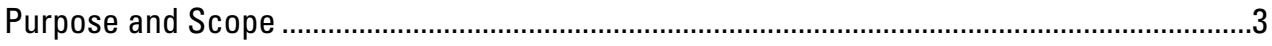

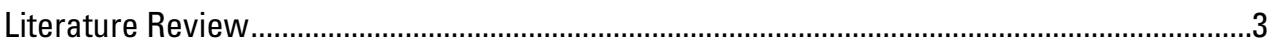

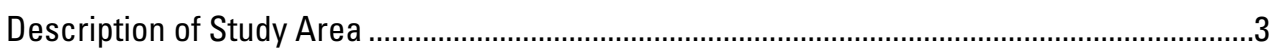

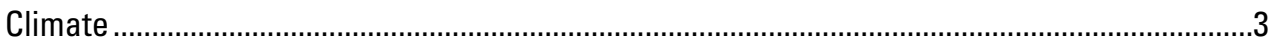

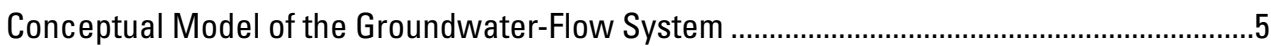

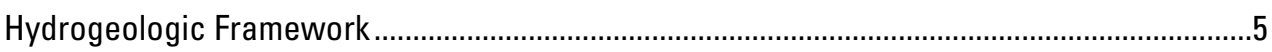

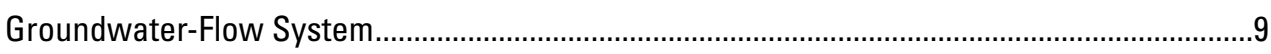

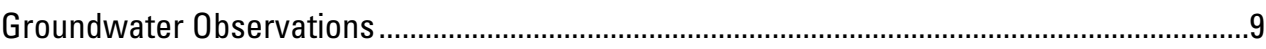

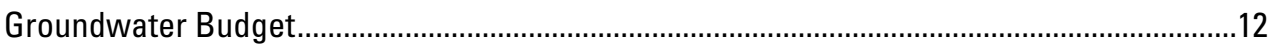

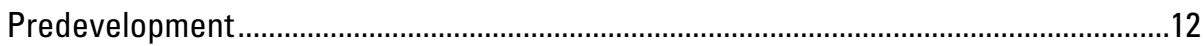

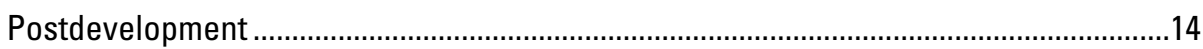

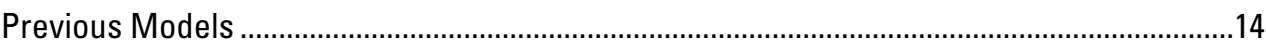

Simulation of Groundwater Flow........................................................................................

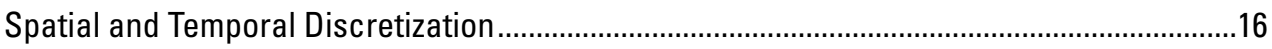

Boundary Conditions and System Stresses ........................................................................17

Hualapai Valley Basin Withdrawal and Recharge Scenarios.............................................22

Model Parameter Estimation and Uncertainty Quantification...................................................26

Prior Parameter Distribution .......................................................................................

Parameter Estimation with PESTPP-IES ..................................................................27

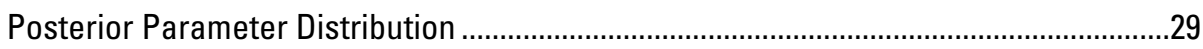

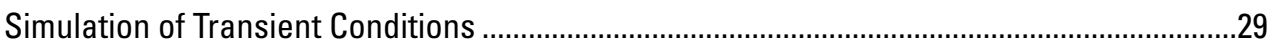

Simulation of Future Withdrawal and Enhanced Recharge Scenarios ....................................31

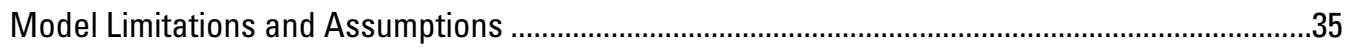

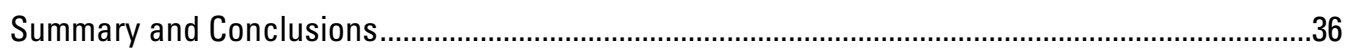

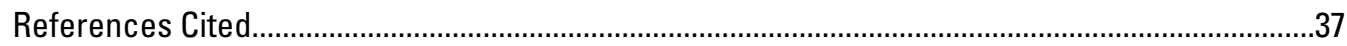

Appendix 1. Simulated Groundwater Levels 1935-2080 ……....................................................41

Appendix 2. Parameter Estimation and Uncertainty Analysis of HVHM with PESTPP-IES..............58

Appendix 3. Summary of Groundwater-Level Observation Sites................................................60 


\section{Figures}

1. Map showing the Hualapai Valley Hydrologic Model study area and surrounding region........ 2

2. Map showing the annual precipitation 30 -year normal, in inches per year ................................ 4

3. Map showing surface geology and fault locations of the Hualapai Valley.................................. 6

4. Maps showing subsurface basin geometry models and lithologies of the Kingman and Hualapai subbasins

5. Map showing generalized groundwater-flow directions based on groundwater-levels from select well locations

6. Graphs showing observed depth to groundwater levels, in feet, at select wells in the basin fill of the Hualapai Valley Basin aquifer

7. Map showing repeat microgravity monitoring locations and gravity change from 2009 to 2019, in the Hualapai Valley Basin, Mohave County, Arizona ..................................................... 13

8. Map showing the Hualapai Valley Hydrologic Model grid and material property zones......... 16

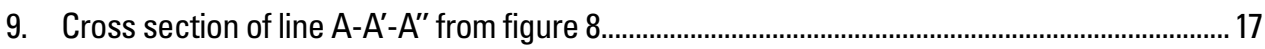

10. Model showing mean annual simulated recharge applied to each model cell, in meters per day.

11. Graph showing the simulated annual mean natural recharge for Kingman and Hualapai subbasins and the total annual mean natural recharge for both subbasins, in acre-feet per year...

12. Map of southeast Hualapai Valley Basin Model cells simulating inflows from Truxton Wash.

13. Satellite image of and conceptual cross-sectional view across the north boundary of Hualapai Valley Hydrologic Model along Hualapai Wash to Lake Mead

14. Map of Hualapai Valley Hydrologic Model area showing simulated municipal pumping locations and graph showing total withdrawal rates of municipal pumping ..

15. Map of Hualapai Valley Hydrologic Model area showing simulated self-supplied domestic (SSD) locations and graph showing total withdrawal rates of SSD pumping..

16. Map showing model cells simulating agricultural withdrawals beginning in 2019,2024 , and 2029 .

17. Map of model and land-ownership groups and graph showing expected annual withdrawals by each group, in acre-feet per year

18. Map of simulated locations and graph showing total rates of incidental recharge from septic fields and leaky infrastructure, in acre-feet per year.

19. Map of southern part of the Hualapai Valley Hydrologic Model showing existing and planned enhanced infiltration project locations in the Kingman subbasin 25

20. Map showing site locations of observed groundwater levels and drawdowns used for parameter estimation of the Hualapai Valley Hydrologic Model.

21. Graphs showing objective function reduction over 8 iterations and the posterior ensemble distribution of objective function values. 
22. Two posterior ensemble model realizations of hydraulic conductivity, specific yield, and specific storage showing similar fit to historical observation data.

23. Map views showing mean simulated drawdown for the final withdrawal scenario, standard deviation of drawdown, and uncertainty reduction of drawdown forecasts......31

24. Graph showing net specified and ensemble simulated model outflows through the MODFLOW WEL package.

25. Map views of model area showing specified WEL package fluxes simulated in year 2079 and amount of specified fluxes not simulated owing to desaturation of model cells in year 2079............................................................................................................. 32

26. Graph showing simulated hydraulic heads at site 9 , surface elevation of 3,306 feet................. 33

27. Graph showing simulated hydraulic heads at site 7, surface elevation of 3,152 feet................. 34

28. Graph showing simulated heads at site 2, surface elevation of 2,945 feet.................................34

29. Graph showing simulated mean depth to water, in feet, in Kingman subbasin..........................35

\section{Appendix Figures}

1.1. Graphs of observed and simulated groundwater levels at select wells . .41

3.1. One-to-one plots comparing observed to simulated values, and observed to simulated residual values, organized by observation type

\section{Tables}

1. Predevelopment groundwater-budget values for the Hualapai Valley Basin, Mohave County, Arizona, from Garner and Truini (2011) ............................................................14

2. Groundwater-budget values for the Hualapai Valley Basin, Mohave County, Arizona......15

3. Municipal groundwater pumping in the Hualapai Valley Basin for years 2010-2017 .....21

4. Agricultural groundwater pumpers and projected annual withdrawals (in acre-feet)......22

5. Estimated recharge capacity of existing and planned infiltration projects.....................24

6. Aquifer property characteristics, mean prior parameter multiplier range, and absolute value range.

7. Aquifer property characteristics from base realizations of prior and posterior parameter distributions

\section{Appendix Tables}

1.1. Summary of forecasted groundwater hydraulic heads in years 2050 and 2080 at select locations, all units in feet..

3.1. Summary of groundwater level and groundwater-level change observations used for determining the likelihood of parameter distributions through history matching...... 


\section{Conversion Factors}

U.S. customary units to International System of Units

\begin{tabular}{|c|c|c|}
\hline Multiply & By & To obtain \\
\hline \multicolumn{3}{|c|}{ Length } \\
\hline inch (in.) & 2.54 & centimeter $(\mathrm{cm})$ \\
\hline foot $(\mathrm{ft})$ & 0.3048 & meter $(\mathrm{m})$ \\
\hline mile (mi) & 1.609 & kilometer $(\mathrm{km})$ \\
\hline \multicolumn{3}{|c|}{ Area } \\
\hline acre & 4,047 & square meter $\left(\mathrm{m}^{2}\right)$ \\
\hline square mile $\left(\mathrm{mi}^{2}\right)$ & 2.590 & square kilometer $\left(\mathrm{km}^{2}\right)$ \\
\hline \multicolumn{3}{|c|}{ Volume } \\
\hline cubic foot $\left(\mathrm{ft}^{3}\right)$ & 0.02832 & cubic meter $\left(\mathrm{m}^{3}\right)$ \\
\hline acre-foot (acre-ft) & 1,233 & cubic meter $\left(\mathrm{m}^{3}\right)$ \\
\hline \multicolumn{3}{|c|}{ Flow rate } \\
\hline acre-foot per day (acre-ft/d) & 0.01427 & cubic meter per second $\left(\mathrm{m}^{3} / \mathrm{s}\right)$ \\
\hline acre-foot per year (acre-ft/yr) & 1,233 & cubic meter per year $\left(\mathrm{m}^{3} / \mathrm{yr}\right)$ \\
\hline foot per day (ft/d) & 0.3048 & meter per day $(\mathrm{m} / \mathrm{d})$ \\
\hline foot per year (ft/yr) & 0.3048 & meter per year (m/yr) \\
\hline \multicolumn{3}{|c|}{ Hydraulic conductivity } \\
\hline foot per day (ft/d) & 0.3048 & meter per day $(\mathrm{m} / \mathrm{d})$ \\
\hline \multicolumn{3}{|c|}{ Hydraulic gradient } \\
\hline foot per mile $(\mathrm{ft} / \mathrm{mi})$ & 0.1894 & meter per kilometer $(\mathrm{m} / \mathrm{km})$ \\
\hline \multicolumn{3}{|c|}{ Transmissivity } \\
\hline foot squared per day $\left(\mathrm{ft}^{2} / \mathrm{d}\right)$ & 0.09290 & meter squared per day $\left(\mathrm{m}^{2} / \mathrm{d}\right)$ \\
\hline
\end{tabular}

Temperature in degrees Celsius $\left({ }^{\circ} \mathrm{C}\right)$ may be converted to degrees Fahrenheit $\left({ }^{\circ} \mathrm{F}\right)$ as follows:

$$
{ }^{\circ} \mathrm{F}=\left(1.8 \times{ }^{\circ} \mathrm{C}\right)+32 .
$$

Temperature in degrees Fahrenheit $\left({ }^{\circ} \mathrm{F}\right)$ may be converted to degrees Celsius $\left({ }^{\circ} \mathrm{C}\right)$ as follows:

$$
{ }^{\circ} \mathrm{C}=\left({ }^{\circ} \mathrm{F}-32\right) / 1.8 \text {. }
$$

\section{Datum}

Vertical coordinate information is referenced to the North American Vertical Datum of 1988 (NAVD 88).

Horizontal coordinate information is referenced to the North American Datum of 1983 (NAD 83).

Elevation, as used in this report, refers to distance above the vertical datum.

Depth reported as below the land surface are measured from the land-surface datum, a plane that is approximately at land surface at each well where measured. 


\section{Abbreviations}

$\begin{array}{ll}\text { ADWR } & \text { Arizona Department of Water Resources } \\ \text { BAS6 } & \text { basic } \\ \text { bls } & \text { below land surface } \\ \text { DIS } & \text { discretization } \\ \text { DRN } & \text { drain } \\ \text { GLM } & \text { Gauss-Levenburg-Marquardt } \\ \text { GWSI } & \text { Groundwater Site Inventory } \\ \text { HVHM } & \text { Hualapai Valley Hydrologic Model } \\ \text { INA } & \text { irrigation nonexpansion area } \\ \text { Ma } & \text { million years ago } \\ \text { NAD 83 } & \text { North American Datum of 1983 } \\ \text { NAVD 88 } & \text { North American Vertical Datum of 1988 } \\ \text { NGVD 29 } & \text { National Geodetic Vertical Datum of 1929 } \\ \text { PESTPP-IES } & \text { Parameter Estimation and Uncertainty Quantification Iterative Ensemble } \\ \text { ppm } & \text { Smoother software } \\ \text { RCH } & \text { parts per million } \\ \text { SWB } & \text { recharge } \\ \text { UPW } & \text { Soil-Water Balance } \\ \text { USGS } & \text { upstream weighting } \\ \text { WEL } & \text { U.S. Geological Survey } \\ \end{array}$




\title{
Assessing Potential Groundwater-Level Declines from Future Withdrawals in the Hualapai Valley, Northwestern Arizona
}

\author{
By Jacob E. Knight, Bruce Gungle, and Jeffrey R. Kennedy
}

\section{Abstract}

A numerical groundwater flow model of the Hualapai Valley Basin in northwestern Arizona was developed to assist water-resource managers in understanding the potential effects of projected groundwater withdrawals on groundwater levels in the basin. The Hualapai Valley Hydrologic Model (HVHM) simulates the hydrologic system for the years 1935 through 2219, including future withdrawal scenarios that simulate large-scale agricultural expansion with and without enhanced groundwater recharge from potential new infiltration basin projects. HVHM is a highly parameterized model (75,586 adjustable parameters) capable of simulating grid-scale variability in aquifer properties (for example, conductivity, specific yield, and specific storage) and system stresses (for instance, natural recharge and groundwater withdrawals). Parameter estimation and uncertainty quantification were performed using an iterative ensemble smoother software (PESTPP-IES) to produce an ensemble of models fit to historical data. Results via the future withdrawal scenario from this ensemble indicate that mean groundwater level will decline at wells in the Kingman subbasin 87 to 128 feet by the year 2050 and 204 to 241 feet by the year 2080. Mean groundwater level is expected to decline at wells in the Hualapai subbasin between 44 and 210 feet by 2050 and between 107 and 350 feet by 2080 . The enhanced recharge scenario results show potential for these declines to be partially mitigated in the Kingman subbasin by between 8 and 23 feet in 2050 and between 23 and 43 feet in 2080. The enhanced recharge scenario has no simulated effect on groundwater levels in the Hualapai subbasin. All planned enhanced infiltration projects are located in the Kingman subbasin, which is simulated to become hydraulically disconnected from the Hualapai subbasin owing to groundwater-level declines before 2050. Mean depth to water in the Kingman subbasin as simulated in the future withdrawal scenario will exceed 1,200 feet between the years 2155 and 2214 (median year 2171). In the future withdrawal plus enhanced recharge scenario, mean depth to water in the Kingman subbasin exceeds 1,200 feet between the years 2163 and 2207 (median year 2180), except for one model realization in which the subbasin does not reach an mean depth to water of 1,200 feet by the end of forecast simulation (year 2220). Simulated dewatering of the basin margins reduces scenario pumping rates by as much as 7 percent in 2029 and 12 percent in 2079 below specified rates. Forecasts of groundwater-level declines are based on the reduced simulated pumping rates.

\section{Introduction}

Hualapai Valley Basin is a broad, internally drained, intermountain desert basin in Mohave County, northwestern Arizona (fig. 1). Basin-fill aquifers are the primary groundwater source for many desert communities, and the residents, commerce, and agriculture in and near to the Hualapai Valley Basin must rely on such groundwater to meet water needs (Garner and Truini, 2011). As in many parts of the western United States, population growth in this part of Arizona is substantial. From 2000 to 2018 the population of the City of Kingman, Arizona, grew from 20,069 to 30,314, an increase of 51 percent (United States Census Bureau, 2019a), whereas the population of Mohave County grew from 155,062 to 209,550, an increase of 35 percent (United States Census Bureau, 2019b). Municipal groundwater pumping, mainly in the Kingman area, decreased nearly 300 acre-feet per year (acre-ft/yr) from 2010 to 2012 and then increased at a rate of over $600 \mathrm{acre}-\mathrm{ft} / \mathrm{yr}$ to 7,843 acre-ft in 2017 (City of Kingman, written commun., 2020). Installation of agricultural wells and related pumping have also been increasing. Irrigation pumping increased from 8,000 to 23,000 acre-ft/yr from 2014 to 2015 and peaked at 35,000 acre-ft in 2017 (Read and Tadayon, 2021) before falling to 17,000 acre-ft in 2018 owing to changes in land ownership.

Water managers in Mohave County have raised concern about the potential for future groundwater development and additional stresses on the groundwater system in the Hualapai Valley Basin. In particular, the City of Kingman, Ariz., water supply is primarily groundwater withdrawn from the Kingman subbasin of the Hualapai Valley Basin, northeast of the city. The potential effects of future water development on the City of Kingman well field have become a top concern to regional water-resource managers. In an attempt to address this situation, in 2016 the Mojave Board of Supervisors petitioned the Director of the Arizona Department of Water Resources (ADWR) to "take whatever actions necessary" to designate the Hualapai Valley Basin an irrigation nonexpansion area (INA), a legal designation in the State of Arizona that prohibits future agricultural well-drilling in order to prevent continued declines in the water table of a designated area. The ADWR Director turned down the request because of an insufficient rate of groundwater-level decline at the time of the request and noted that ADWR cannot consider projected increases in future pumping as cause for current INA designation (Buschatzke, 2016). 


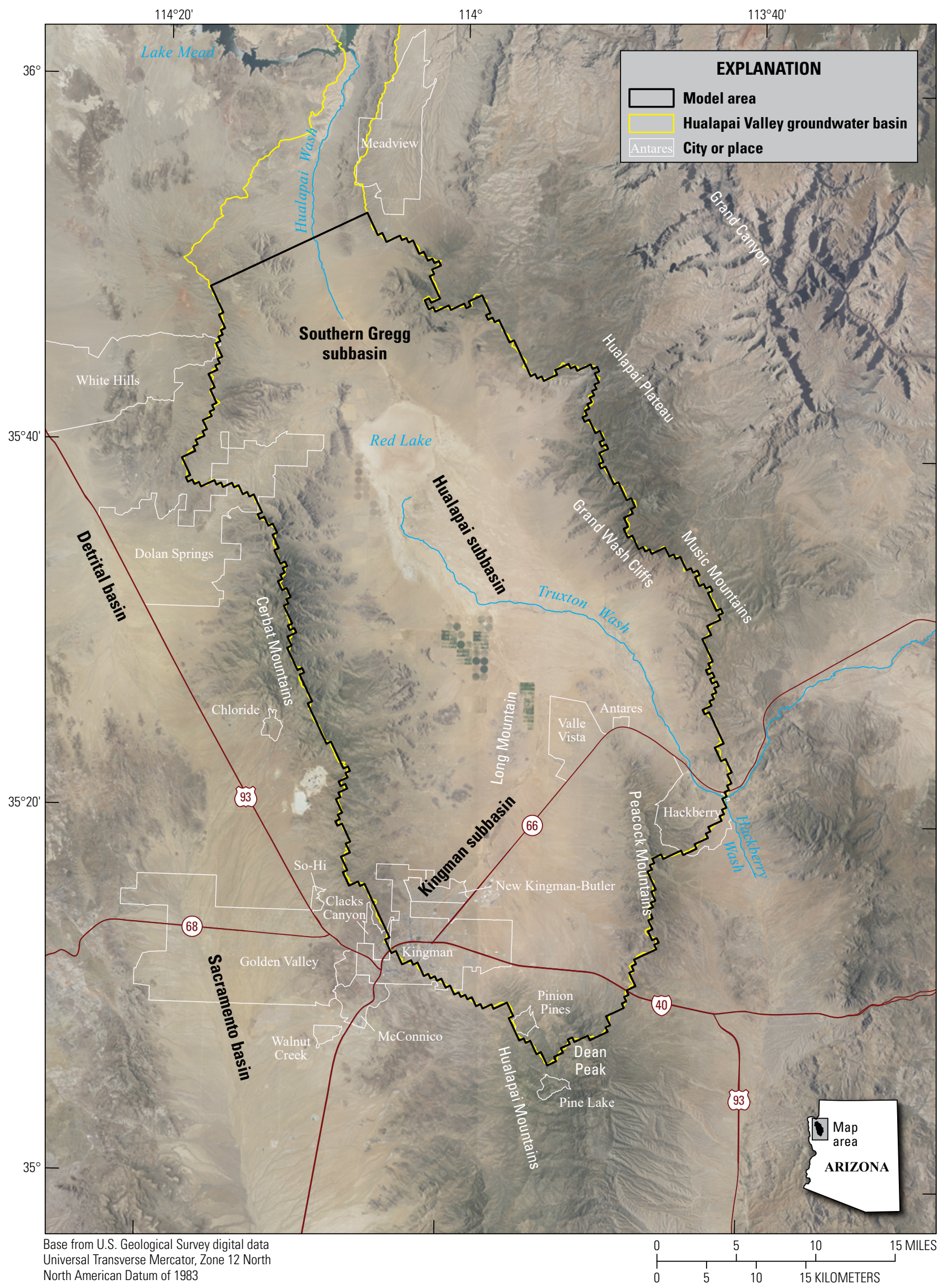

Figure 1. Map showing the Hualapai Valley Hydrologic Model study area and surrounding region. Active model simulation area within the Hualapai Valley Groundwater Basin is limited to the extent of three geologic subbasins defined in a basin geometry model by Truini and others (2012). 
Effective management of groundwater resources is possible when based on a comprehensive scientific understanding of the area's natural resources. Such an approach can help the communities of the Hualapai Valley Basin develop ways to meet their water needs sustainably. Hydrogeologic studies provide information and tools for local water-resource managers to better understand the existing groundwater system and to plan for potential changes in the groundwater system that may result from changes in water use, climate change, and other potential stresses.

To provide information that water-resource managers and others can use to help manage groundwater resources, an assessment of potential groundwater-level declines from future withdrawals was completed by the U.S. Geological Survey (USGS) in cooperation with Mohave County and the City of Kingman. This assessment builds on previous USGS studies to provide estimates of the potential effects of groundwater withdrawals from the Hualapai Valley Basin on groundwater levels of the basin-fill aquifer using withdrawal scenarios provided to the USGS by Mohave County and its partners. These potential effects can be understood through the development of a new groundwater model (the Hualapai Valley Hydrologic Model [HVHM]) that uses the preliminary groundwater flow model of Tillman and others (2013) as a starting point. As a result of HVHM, Mohave County and its partners now have a robust numerical tool—an updated numerical groundwater flow model for the Hualapai Valley Basin - that they can use to steer the region toward the sustainable use of its groundwater resources.

\section{Purpose and Scope}

The purpose of this report is to describe an assessment of potential groundwater-level declines from future withdrawals in the Hualapai Valley in northwestern Arizona using the HVHM numerical groundwater flow model. The HVHM simulates the hydrologic system for the years 1935 through 2219, including future withdrawal scenarios that simulate large-scale agricultural expansion with and without enhanced groundwater recharge from potential new infiltration basin projects.

\section{Literature Review}

Gillespie and others (1966), Gillespie and Bentley (1971), Laney (1979), Remick (1981), and Anning and others (2007) have all conducted groundwater investigations in Hualapai Valley Basin. Tadayon (2005) compiled water-use data for the Hualapai Valley Basin. Ivanich and Conway (2009) used gravity data to estimate total available groundwater storage in the Hualapai Valley Basin. Langenheim and others (2010) investigated gravity and magnetic anomalies in the northern Colorado River extensional corridor and the Lake Mead area.

In 2005, the USGS, in cooperation with ADWR, began hydrogeologic studies in Hualapai Valley Basin and in Detrital and Sacramento Valley basins adjacent to the west, as part of the Rural Watershed Initiative program. Results from these USGS studies are documented in four USGS series reports and a USGS map and consist of an investigation of groundwater occurrence, groundwater movement, and groundwater-level change (Anning and others, 2007), an estimate of groundwater budgets (Garner and Truini, 2011), an updated geologic map of the basins (Beard and others, 2011), and a hydrogeologic framework and estimates of groundwater storage (Truini and others, 2013).

\section{Description of Study Area}

Hualapai Valley Basin is a broad, internally drained, intermountain desert basin located in Mohave County, northwestern Arizona, within the Basin and Range Physiographic Province (fig. 1; Fenneman, 1931) and contains no perennial surface-water features. As defined by ADWR, Hualapai Valley Basin has an area of about 1,200 square miles ( $\mathrm{mi}^{2}$; Arizona Department of Water Resources, 2010) and comprises three subbasins, the southern Gregg subbasin, the Hualapai subbasin, and the Kingman subbasin (fig. 1). Hualapai Valley Basin ranges in elevation from about 1,100 feet (ft) at Lake Mead to almost $7,000 \mathrm{ft}$ in the Cerbat Mountains along its west boundary and to $8,000 \mathrm{ft}$ at Dean Peak in the Hualapai Mountains near the south tip of the basin. The Grand Wash Cliffs form the east boundary, and the White Hills form the northwest boundary of the Hualapai Valley Basin. The community of New Kingman-Butler lies within the Hualapai Valley Basin near the City of Kingman and the community of Hackberry, Ariz., is along the southeast edge of the basin near where the Truxton Wash enters the basin and flows northwest to Red Lake.

\section{Climate}

The climate of the Hualapai Valley Basin is arid to semi-arid. Winter daily maximum temperatures typically range from about 50 to $70^{\circ} \mathrm{F}$ and summer daily maximum temperatures range from 90 to $110^{\circ} \mathrm{F}$. Normal reference evapotranspiration is about 80 inches per year on the valley floor (University of Arizona, 2020). Annual precipitation ranges from about 5 to 10 inches on the valley floor and to as much as 17 inches in the mountains (fig. 2). Precipitation patterns are bimodal and consist of winter (November through March) and summer (late June through September) rainy seasons. Winter storms tend to be moderate intensity, mid-latitude low-pressure-system precipitation events that can last a day or more, whereas summer storms are far more localized airmass thunderstorm events that are generated by the North American Monsoon (Adams and Comrie, 1997). Summer monsoon thunderstorm precipitation is often intense and can produce an inch or more of precipitation in less than an hour's time. Moisture generated by tropical storms will occasionally enter the area, typically in the fall, and can produce considerable precipitation. Otherwise, October into mid-November can be fairly dry. A longer and more distinct seasonal drought begins in April and lasts until the summer monsoon rains begin in early July (Anning and others, 2007; Garner and Truini, 2011; Truini and others, 2013; Tillman and others, 2013). 


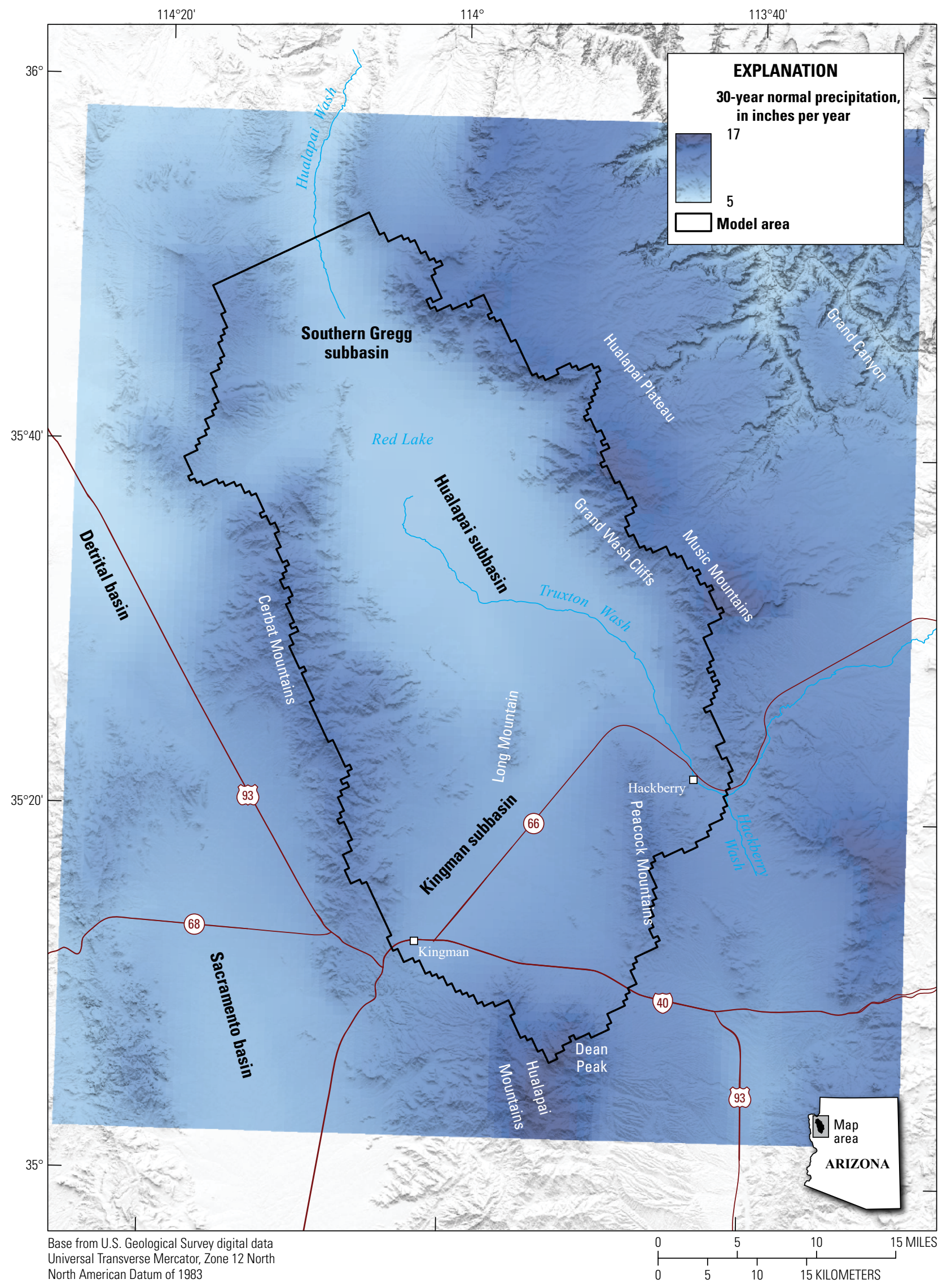

Figure 2. Map showing 30-year normal (1981-2019) annual precipitation, in inches per year (PRISM Climate Group, 2020). 


\section{Conceptual Model of the Groundwater-Flow System}

Tillman and others (2013, p. 5) provide the following explanation of conceptual models:

"A conceptual model of a groundwater-flow system incorporates a general understanding of the location and rate of inputs into the system, how groundwater moves through the system, and where and at what rate groundwater discharges from the system. Conceptual models are based on such hydrogeologic information as estimates of aquifer recharge, measured water levels in wells, and hydrologic properties of aquifer materials, among other factors. The [conceptual] models will be modified through time as improved information is obtained from new data and analyses."

Tillman and others (2013) also note that although numerical groundwater flow models are generally calibrated to groundwater levels, the groundwater levels may, in fact, be explained by many different conceptual models. What follows is a general description of the conceptual model on which this report is based.

\section{Hydrogeologic Framework}

Tillman and others (2013) include a chronological overview of the physical processes that led to the current hydrogeologic framework of the northwest alluvial basins. A brief summary of that overview focused primarily on the Hualapai Valley Basin is included here.

The Hualapai Valley Basin lies within the Basin and Range Province (Fenneman, 1931), and was formed by extensional faulting during the Miocene. The basin is underlain by Proterozoic crystalline basement rocks that consist of deformed metamorphic gneiss and schist and laterintruded granite. Paleozoic sedimentary rocks were deposited on an unconformity in the basement rocks. Subsequently, the study area was locally intruded by Late Cretaceous plutons and uplifted, which exposed basement rocks in the core of the uplift. Erosion subsequent to the Laramide uplift removed sedimentary deposits of Paleozoic and Mesozoic age. This created a beveled erosional surface on lower Paleozoic rocks of the western margin of the Colorado Plateau. The erosion was accompanied by the formation of large paleovalleys that drained northeastward off the uplift and onto the Colorado Plateau, including a paleovalley between the Cerbat and Hualapai Mountains in the vicinity of the City of Kingman (fig. 3).

Volcanism and plutonism began about 20 million years ago (Ma) and were followed by the Basin and Range crustal extension that peaked about 15-13 Ma, which resulted in highly tilted fault blocks bound by north-northwest-striking faults. The resulting basins (including the then newly formed Hualapai Valley Basin) filled with middle Miocene volcanic rocks and older sedimentary deposits. Extensional faulting from about 13 to $8 \mathrm{Ma}$ formed subbasins in these middle Miocene basins; the bedrock in these subbasins is 0.4 to $2.7 \mathrm{mi}$ beneath the modern land surface. The subbasins were internally drained and were filled with fine sand, silt, clay, and evaporite deposits. The Hualapai Limestone was deposited in lacustrine environments at the northern end of Hualapai Valley at this time (late Miocene). In contrast to the older rocks, these deposits are commonly flat lying or mildly tilted. Integration of the Colorado River drainage ended interior-basin deposition, and the subbasins were overlapped and mostly buried by surficial deposits and playa deposits of early Pliocene and Pleistocene and Pleistocene and Holocene age, respectively. Although water-bearing zones do occur in the rocks of the surrounding mountains, water-saturated sedimentary deposits that fill the Hualapai Valley Basin form the principal aquifer, which is herein referred to as the basin-fill aquifer (basin-fill and surficial deposits of Miocene and younger age on fig. 3; Anning and others, 2007).

A basin geometry model for the Hualapai Valley Basin (Truini and others, 2012) reveals three subbasins: the Kingman, Hualapai, and southern Gregg subbasins. For the purposes of this report, the southern Gregg subbasin is considered part of the Hualapai subbasin; the distinction between the Hualapai subbasin and the Kingman subbasin is more important to the hydrologic conditions simulated by HVHM. Saturated basin fill in the Kingman subbasin consists of a mixture of fine- to coarse-grained sedimentary deposits. The central part of the Kingman subbasin is as much as 1,200 meters $(\mathrm{m} ; 3,937 \mathrm{ft})$ deep. The Hualapai subbasin is larger and deeper than the Kingman subbasin and contains a thick halite body (Faulds and others, 2016) from about $400 \mathrm{~m}$ below land surface (bls) down to a total basin depth of about 4,300 $\mathrm{m}(14,107 \mathrm{ft})$ bls. Fine-grained alluvial fan and playa deposits overlie the halite body (fig. $4 C-D$ ). The Hualapai and Kingman subbasins are separated by a shallow bedrock high that is exposed at the surface in Long Mountain. Well logs and gravity data indicate maximum depths to this bedrock high to be $100 \mathrm{~m}$ bls to the west and $200 \mathrm{~m}$ bls to the east of the mountain (fig. $4 A-B$ ).

The Kingman subbasin shallows substantially to the southeast of the Kingman Fault, an inferred normal fault based on geophysical data (fig. 3). Depth to basement is generally less than $300 \mathrm{~m}$ bls in this area, and more of the surface is covered by basin fill of Tertiary and Quaternary age as opposed to the younger basin fill of Quaternary age that covers the rest of the subbasin (Truini and others, 2012; fig. $4 A-B)$. 


\section{EXPLANATION}

Younger surficial deposits (Pleistocene and Holocene)

\begin{tabular}{|c|c|}
\hline Qw & Valley-axial wash alluvium \\
\hline Qa & Younger alluvial-fan deposits \\
\hline Qe & Eolian sand \\
\hline Qp & Playa deposits \\
\hline Qpo & Older playa deposits \\
\hline Qty & Younger Truxton Wash alluvial-fan deposits \\
\hline Qto & Older Truxton Wash alluvial-fan deposits \\
\hline
\end{tabular}

Older surficial deposits (Pliocene and Pleistocene)

QTa Older alluvial-fan deposits

Younger basin-fill deposits (late Miocene)

Tsy Clastic deposits and

\begin{tabular}{|c|c|}
\hline $\mathrm{Tb}$ & Bouse Formation \\
\hline Th & Hualapai Limestone \\
\hline
\end{tabular}

\section{Older basin-fill deposits (middle Miocene)}

Tso Conglomerate, sandstone, and breccia

\section{Volcanic rocks (middle and late Miocene)}

Tv Mafic and felsic volcanic rocks and ash-flow tuff

\section{Sedimentary rocks (early Paleozoic)}

Pzu Siliciclastic rocks and carbonate

\section{Crystalline basement rocks (Proterozoic, Cretaceous, and Miocene)}

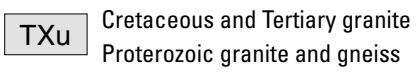

Water

\section{Faults}

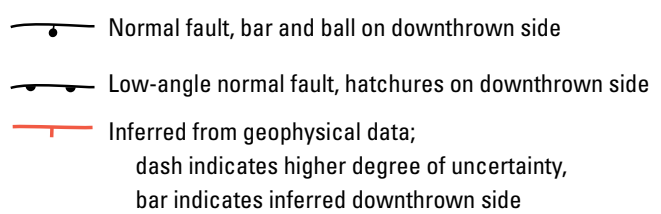

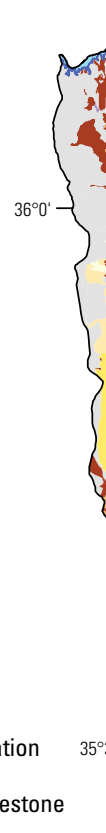
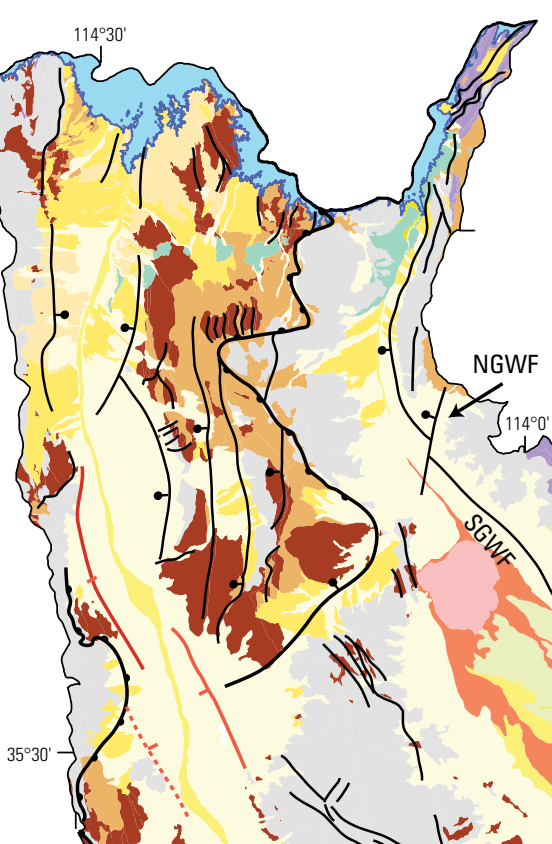


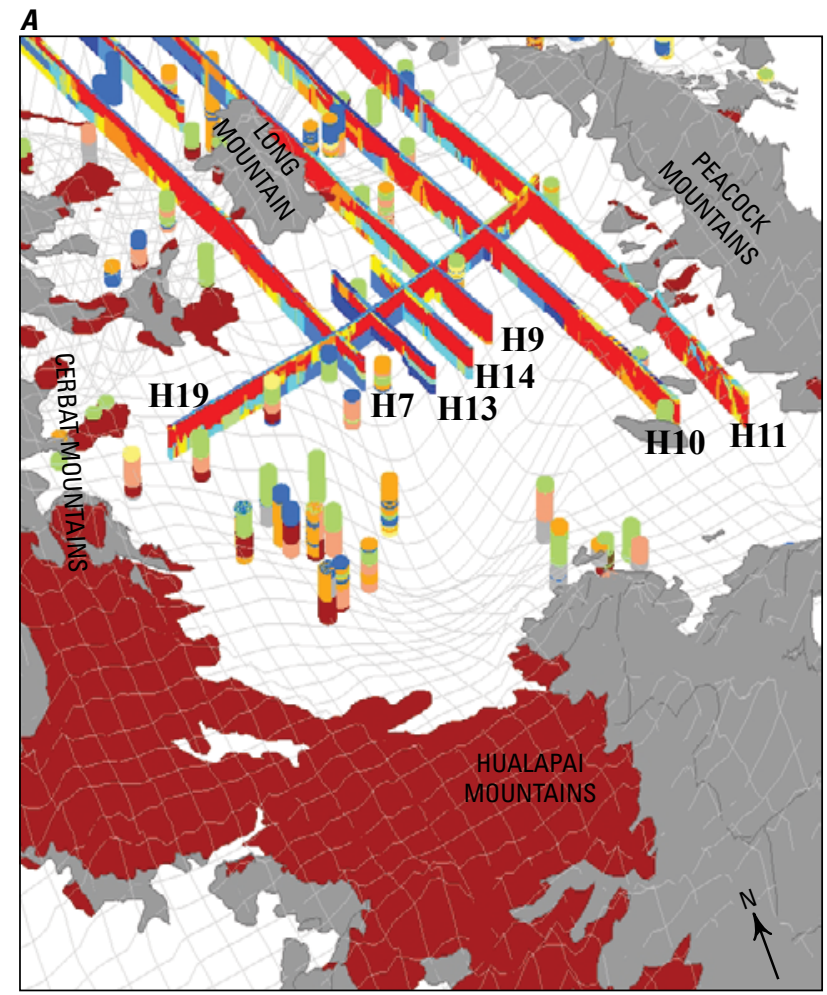

B
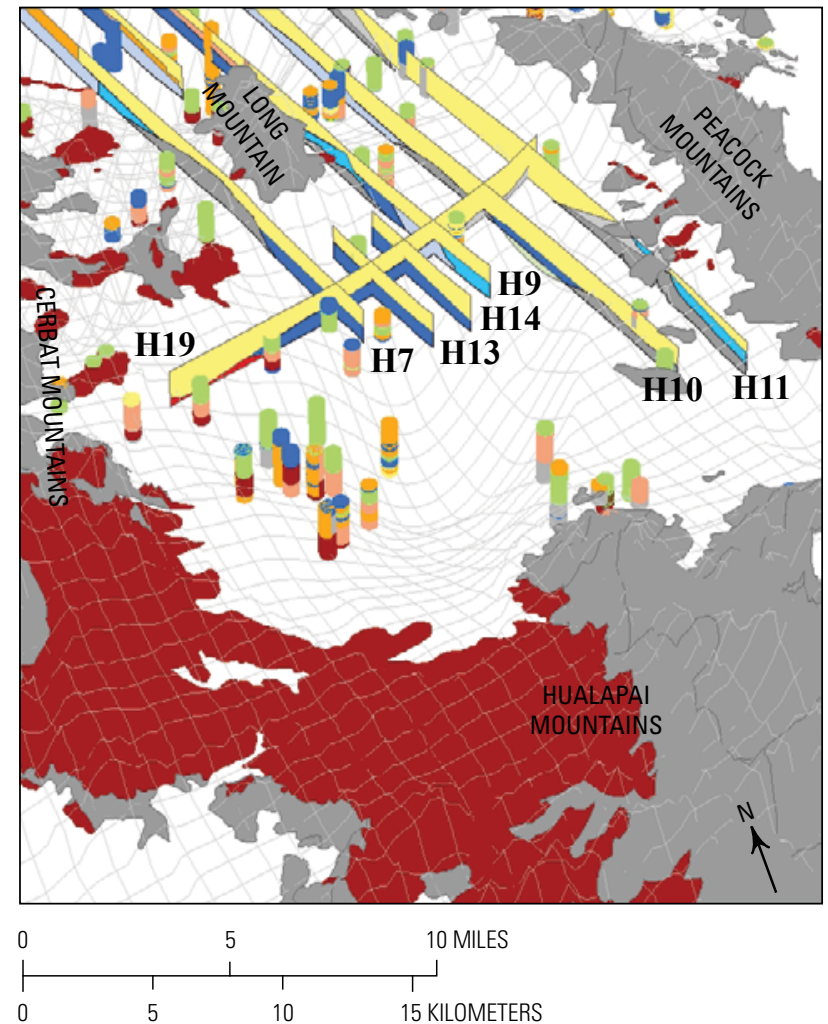

(Scale approximate)

VERTICAL EXAGGERATION ×5

\section{EXPLANATION}

Transient electromagnetic resistivity values, in ohm-meters

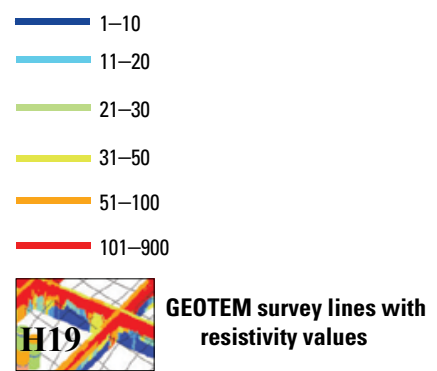

Lithology, from well logs

$\square$ Coarse-grained basin fill

$\square$ Medium-grained basin fill

$\square$ Evaporite

$\square$ Fine-grained basin fill

$\square \quad$ Indurated sediments

$\square$ Undifferentiated sediments

$\square$ Crystalline rocks

Volcanic rocks

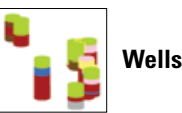

Lithologic units, from interpreted resistivity

$\square$ Unsaturated coarse-grained basin fill

$\square \quad$ Unsaturated medium-grained basin fill

$\square \quad$ Unsaturated fine-grained basin fill

$\square$ Saturated coarse-grained basin fill

$\square \quad$ Saturated medium-grained basin fill

$\square$ Saturated fine-grained basin fill

$\square \quad$ Crystalline rocks

$\square$ Volcanic rocks

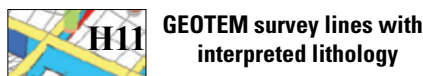

Bedrock lithology, from geologic map (fig. 3)

Volcanic rocks

$\square \quad$ Crystalline rocks

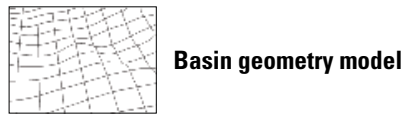

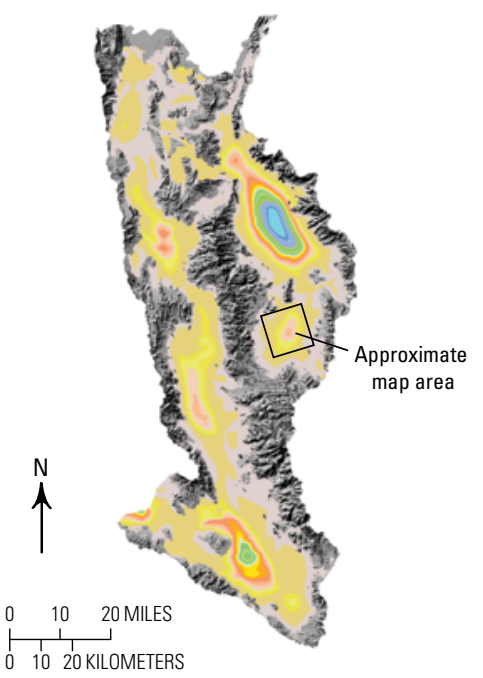

Figure 4. Maps showing subsurface basin geometry models and lithologies of the Kingman and Hualapai subbasins. $A$, Map of Kingman subbasin showing transient electromagnetic resistivity values and the lithology interpreted from them. $B$, Map of Kingman subbasin showing lithology as interpreted from well logs. $C$, Map of the Hualapai subbasin showing transient electromagnetic resistivity values and the lithology interpreted from them. $D$, Map of Hualapai subbasin showing lithology as interpreted from well logs. Figures modified from Truini and others (2013). 

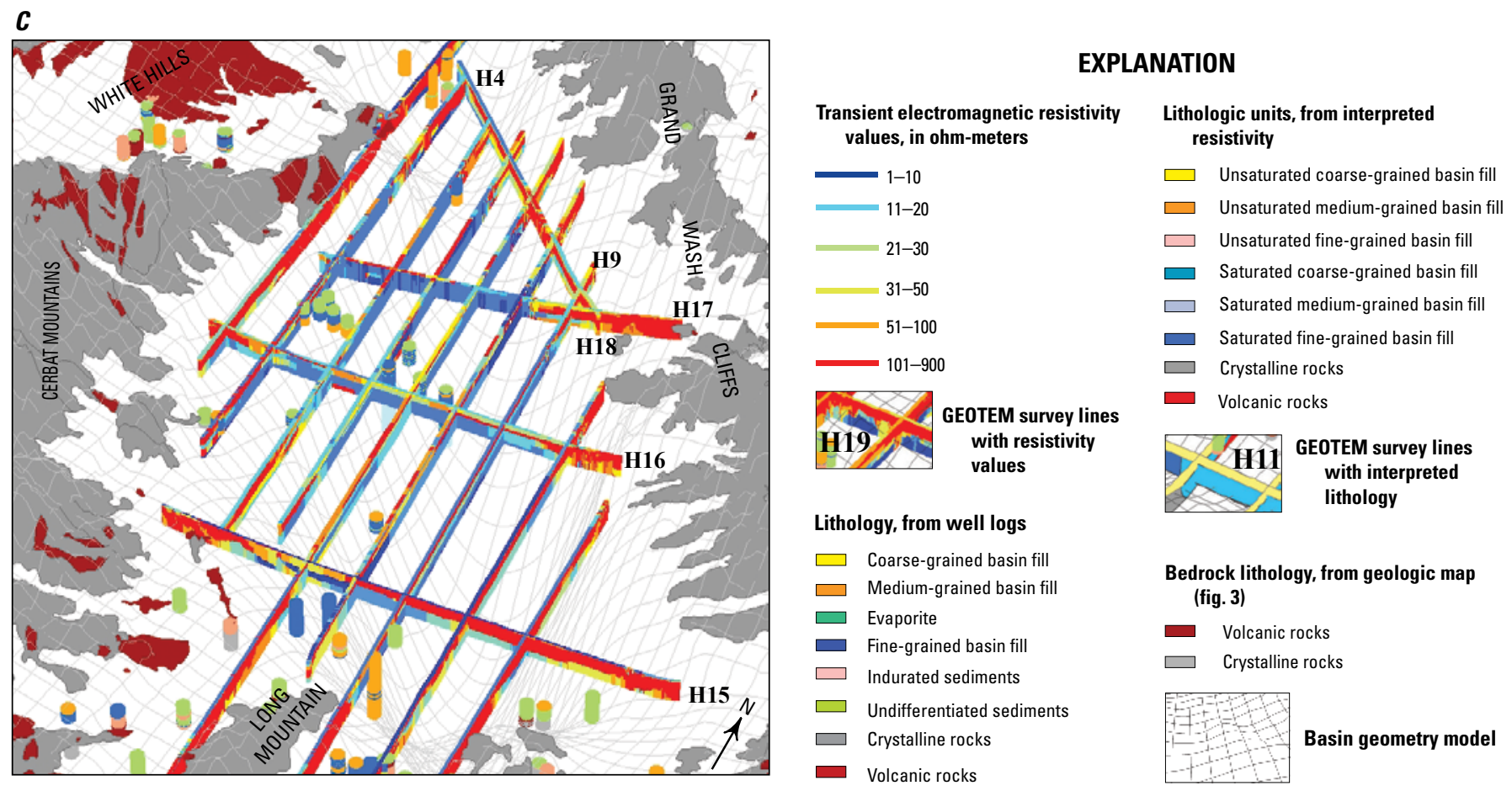

$\boldsymbol{D}$

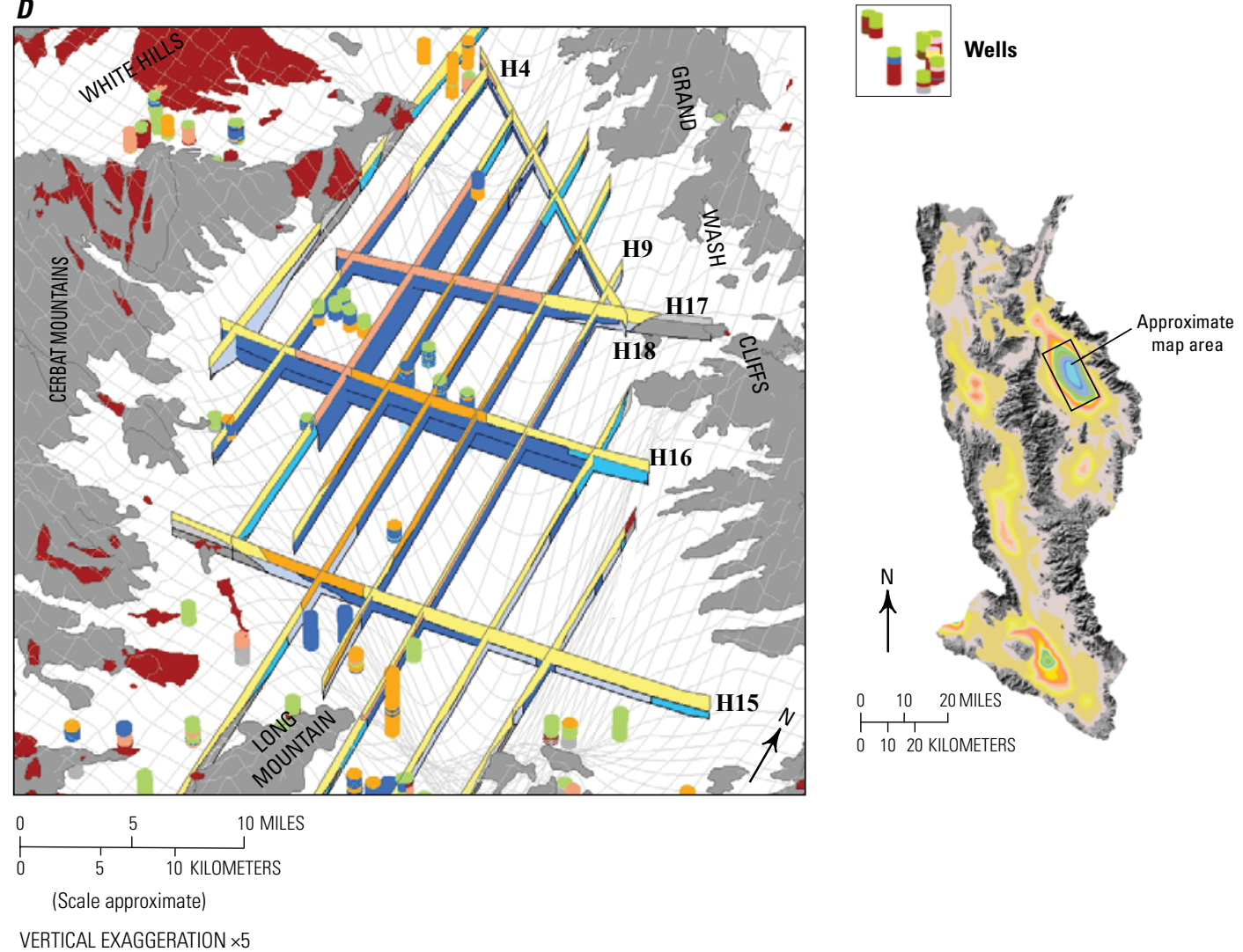

Figure 4. Maps showing subsurface basin geometry models and lithologies of the Kingman and Hualapai subbasins. $A$, Map of Kingman subbasin showing transient electromagnetic resistivity values and the lithology interpreted from them. $B$, Map of Kingman subbasin showing lithology as interpreted from well logs. $C$, Map of the Hualapai subbasin showing transient electromagnetic resistivity values and the lithology interpreted from them. $D$, Map of Hualapai subbasin showing lithology as interpreted from well logs. Figures modified from Truini and others (2013).-Continued 


\section{Groundwater-Flow System}

Groundwater recharge primarily occurs along the mountain fronts in Hualapai Valley Basin, and the groundwater then flows from those areas toward the center of the basin and then along the basin axis to the north where it discharges from the basin into Lake Mead (fig. 5; Anning and others, 2007). A small amount of groundwater enters the basin from the southeast through infiltration in the ephemeral Truxton Wash which enters the basin near Hackberry, Ariz., and then flows northwest into the ephemeral Red Lake in the central part of the basin. Such infiltration only occurs during major precipitation events (Tillman and others, 2013). Groundwater-level elevations (hydraulic heads) in the basin-fill aquifer along the northwest-southeast axis of Hualapai Valley Basin range from less than 1,900 $\mathrm{ft}$ in the northern part of the Hualapai Valley to greater than 2,700 ft in the southern part of the valley. The potentiometric surface (a surface representing the total hydraulic head of groundwater) in the central part of Hualapai Valley Basin, which contains Red Lake, is relatively flat with a gradient of about $7 \mathrm{ft}$ per mile and groundwater hydraulic head elevations (measured in 2006) between 2,402 and 2,514 (Anning and others, 2007). Red Lake playa is at the center of a closed basin and occasionally retains surficial runoff as a result of a minor topographic divide near North Pierce Ferry Road. This is a vadose playa that is disconnected from the water table and therefore does not discharge groundwater at the surface (Garner and Truini, 2011). However, groundwater in the central part of Hualapai Valley Basin flows north underneath the topographic divide.

\section{Groundwater Observations}

The existing groundwater monitoring network in the Hualapai Valley Basin is made up of 19 nonpumping groundwater index wells measured annually with an electric or steel measuring tape by ADWR and 3 additional wells measured quarterly by the USGS. Three of the ADWR wells and one of the USGS wells include pressure transducers that record observations once every 6 hours (ADWR) or once every hour (USGS). Collection of groundwater levels by the USGS follow methods by Cunningham and Schalk (2011). The groundwater monitoring locations are relatively evenly spread across Hualapai Valley Basin. ADWR also conducts comprehensive well sweeps across the basin every 5 to 15 years. Water levels are measured by ADWR at as many wells as are available and measurements follow a standard protocol regarding recent well pumping at or near the subject well. Water-level data from recent sweeps completed in 2006 and 2018 were incorporated as history-matching targets into the model parameter estimation process as detailed below.

Depth-to-water measurements as of 2006 ranged from less than $100 \mathrm{ft}$ bls in the mountains, to about $1,000 \mathrm{ft}$ bls in the southern part of the basin. Although there were no waterlevel data available for the northern end of the Hualapai Valley Basin adjacent to Lake Mead, groundwater hydraulic head elevations were probably comparable to lake elevations, similar to Detrital Valley basin (Anning and others, 2007). The potentiometric-surface gradient in northern Hualapai Valley Basin, about $39 \mathrm{ft}$ per mile, was much steeper than in the southern and central parts of the basin. In the southern part of Hualapai Valley Basin, groundwater altitude data indicated the presence of a cone of depression northeast of the City of Kingman (Anning and others, 2007). Although groundwater in that area flowed toward the cone, groundwater movement near the community of Valle Vista was northward in 2006, to the east of Long Mountain (figs. 1, 5). An elevated water-level altitude in a well in sec. 2, T. 22 N., R. 16 W., about midway between the city of Kingman and Valle Vista (2,808 ft in 2006; Anning and others, 2007), may have marked the north end of the cone of depression at that time, or it may have been the result of mounding of water from recharge occurring at the nearby City of Kingman Wastewater Treatment Plant. In general, groundwater-flow directions in 2006 were probably similar to those of the predevelopment system with the exception of the effect on the flow system by the pumpinginduced cone of depression and other minor, localized pumping effects (Tillman and others, 2013).

Long-term water-level changes varied for different areas of the Hualapai Valley Basin. Summary statistics from Anning and others (2007) indicated that the most extreme changes observed were a 1979-80 to 2006 decline of about $135 \mathrm{ft}$ in one well and a rise of about $108 \mathrm{ft}$ in another. These two wells were completed in fractured volcanic and granitic rocks, and the large fluctuations were likely due to low groundwater storage coefficients associated with water-bearing consolidated rocks. Water-level changes for many of the hydrographs Anning and others (2007) examined were small, however.

Hydrographs and net water-level changes for the area north of Long Mountain were reviewed by Anning and others (2007) and generally indicated small but steady water-level increases of up to about $8 \mathrm{ft}$, chiefly over the period 1980 to 2006. With a few exceptions, net water-level changes for 1996-2006, 1979-80 to 2006, and 1964-65 to 2006 indicated either no change or rising water levels for most wells in this area. Water levels continued to rise until about 2012 (Arizona Department of Water Resources, 2020). After that, water levels of the southernmost wells (B-24-16 01DDD1 and B-26-17 35AAA) began dropping sharply. Water levels in wells farther to the north (B-27-16 33BAA and B-28-17 31CCC1) have continued to rise throughout the period of record, to 2020 (Arizona Department of Water Resources, 2020). However, net water-level changes in four wells northeast of Dolan Springs, Ariz., for 1996 to 2006 and 1979-80 to 2006 showed declining water levels (Anning and others, 2007). At least one well northeast of Dolan Springs (B-26-18 03AAA1) has had periods of both water level increases and declines between 1980 and 2020 (fig. 6).

Hydrograph data for the area north of Hackberry, near Truxton Wash, showed some early water-level declines followed more recently by variable or consistent water levels (ADWR, 2020). The hydrograph for B-24-14 28CAD, showed a steady decline of about $60 \mathrm{ft}$ from 1944 to 1991 followed by fluctuating water levels through 2020. Water level increases in Truxton Wash appear to follow one or more wet years and declines follow drier 


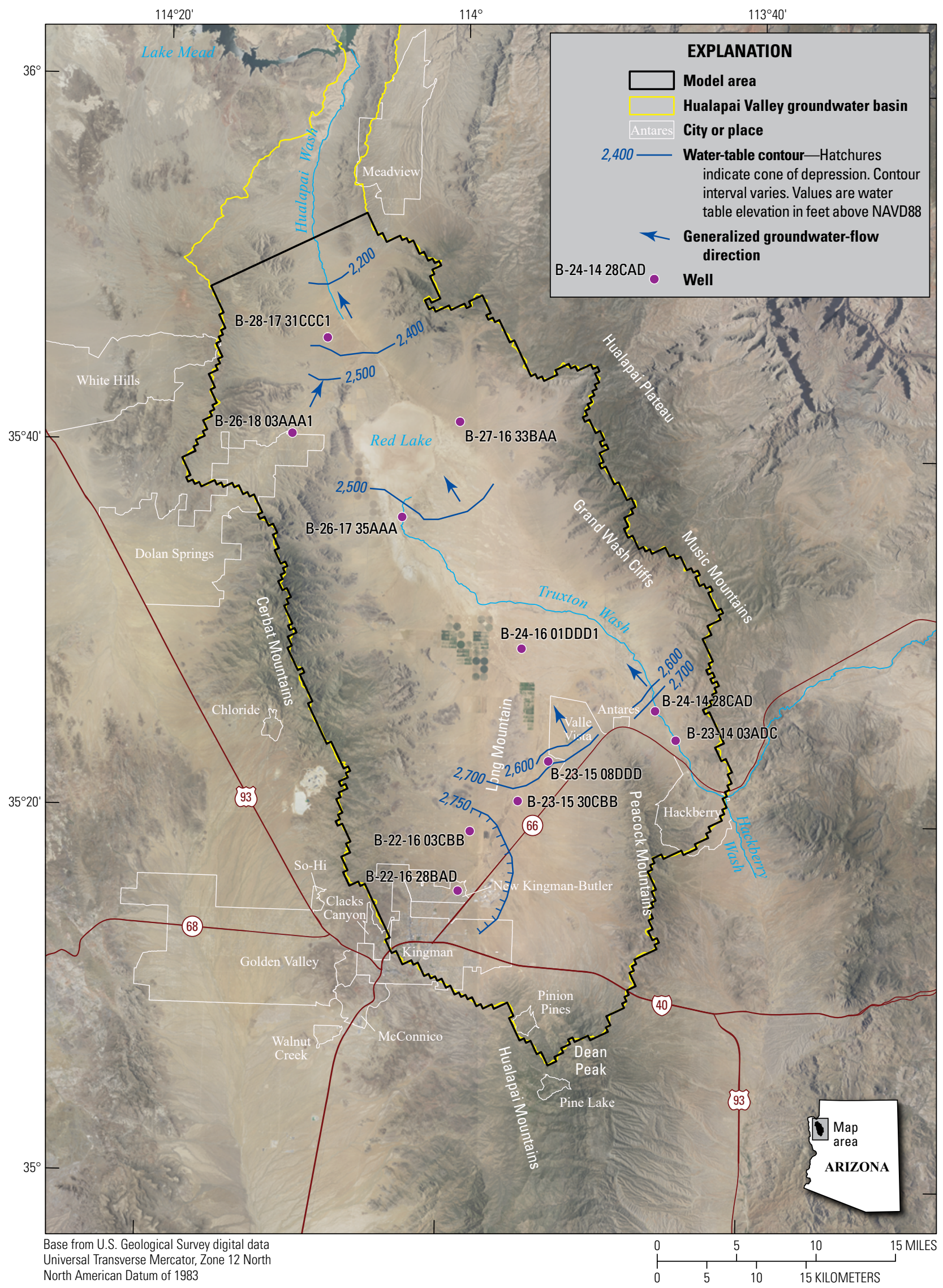

Figure 5. Map showing generalized groundwater-flow directions based on groundwater-level contours estimated from 2006 measurements at select well locations. Adapted from Anning and others, 2007. 

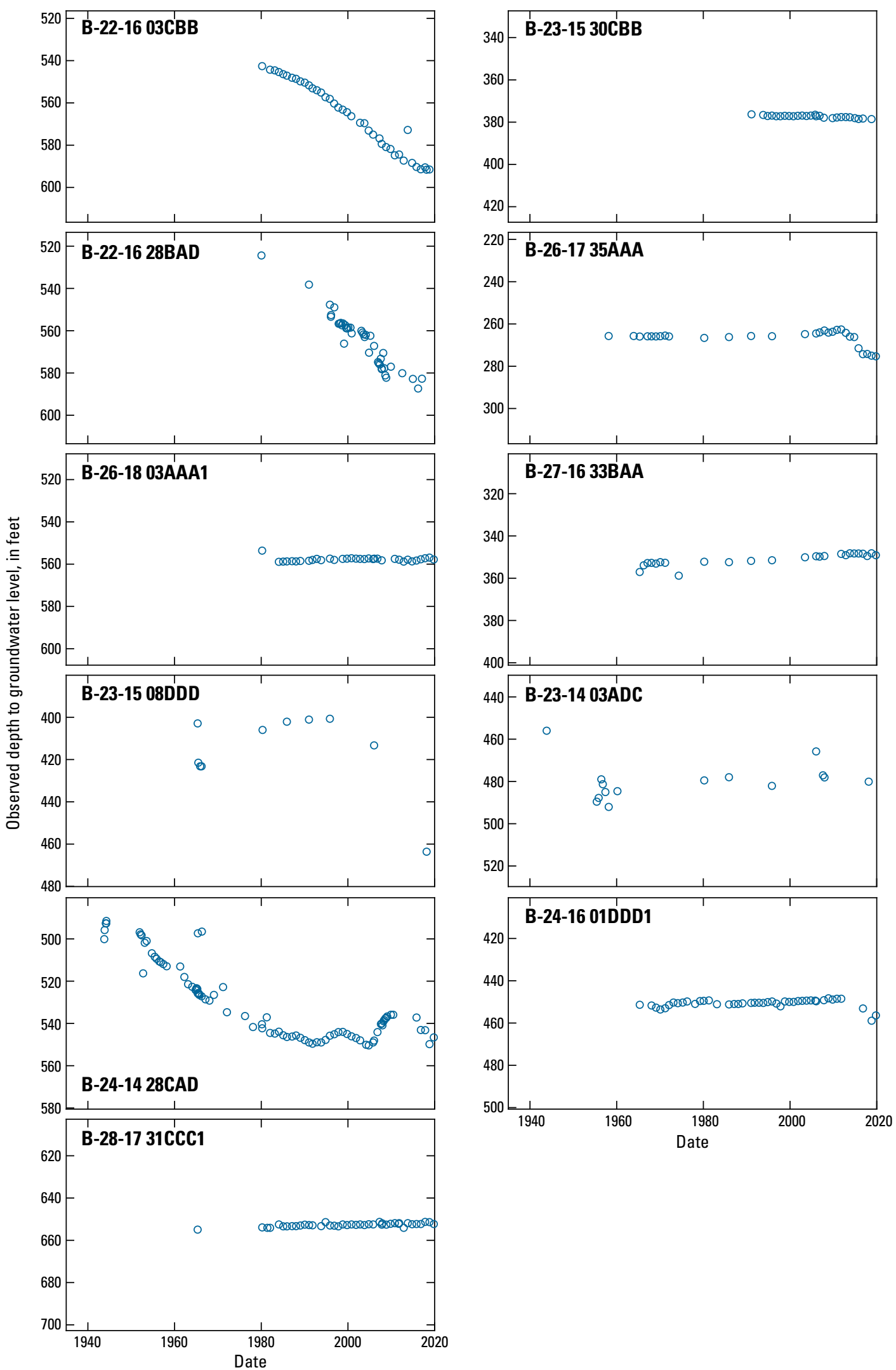

Figure 6. Graphs showing observed depth to groundwater levels, in feet, at select wells in the basin fill of the Hualapai Valley Basin aquifer. All data retrieved from Arizona Department of Water Resources Groundwater Site Inventory database (Arizona Department of Water Resources, 2020). 
years based on precipitation data (University of Arizona, 2020). The hydrograph for B-23-14 03ADC showed water levels dropped about $40 \mathrm{ft}$ from 1944 to the mid-1950s. The next measurement, in 1980, was about $10 \mathrm{ft}$ higher. Six water level measurements made at this location since then have remained within a few feet of the 1980 value except for a single data point, an anomalous $10 \mathrm{ft}$ upward spike in 2009. In general, water level data are not sufficiently consistent after 1961 to analyze water level trends at this location (fig. 6).

Hydrograph data showed that net water-level changes for the Hualapai Valley Basin south of Long Mountain through 2020 were in steady decline and had generally been so since as early as the 1960s (ADWR, 2020). From north to south, water levels in well B-23-15 30CBB have declined over $2.5 \mathrm{ft}$ from 1990 to 2020, water levels in well B-22-16 03CBB have declined about $40 \mathrm{ft}$ from 1990 to 2020 and about $50 \mathrm{ft}$ since the beginning of the record in 1980, and water levels in well B-22-16 28BAD have declined $48 \mathrm{ft}$ from 1990 to 2020 and about $76 \mathrm{ft}$ since the record began in 1964. Net water-level changes for most wells in this area before 2006 indicated declining or unchanging water levels. These water-level declines were consistent with the cone of depression previously discussed for the southwestern part of this area near the City of Kingman (Anning and others, 2007; fig. 5).

A repeat microgravity monitoring network was established in the Hualapai Valley Basin in 2008. Repeat microgravity monitoring is a geophysical method used to estimate changes in aquifer storage by measuring small changes in Earth's gravity (Kennedy, 2018). In most environments the relation between change in gravity and change in storage is linear (41.9 microGal $[\mu \mathrm{Gal}]=1 \mathrm{~m}$ of water) and independent of the depth to water and aquifer porosity (Pool and Eychaner, 1995). The microgravity monitoring network is made up of 20 stations constructed to accommodate the A-10 absolute-gravity meter (Kennedy and Bucci, 2021), an instrument that provides a direct measurement of the acceleration of a falling mass. Of these 20 stations, 12 form two parallel transects across Truxton Wash where it enters the Hualapai Valley Basin from the southeast. These transects were surveyed in 2017, 2018, and 2019, but no significant streamflow or recharge events occurred during this time period, and gravity change was below the detection limit (Kennedy and Bucci, 2021).

Microgravity surveys were carried out in 2008, 2009, 2017, 2018, and 2019 (fig. 7; Kennedy and Bucci, 2021) following methods in Kennedy and others (2021). Two stations (HUA-G1 and HUA-G2) are located at the north end of the basin and showed nearly unchanged aquifer storage during the 10 -year period from 2009 to 2019 (Kennedy and Bucci, 2021). Groundwater pumping in this area is minimal, and the lack of storage change corresponds with generally unchanging or small increases in water level (wells B-27-16 33BAA and B-28-17 31CCC1, fig. 6; the latter is collocated with HUA-G2). Station HUA-G3 showed a small increase in storage that may correspond with construction of a nearby nut farm (that is, storage may be increasing locally owing to irrigation, compensated by a decrease in storage elsewhere in the basin). Station HUA-G4, approximately 10 kilometers southwest of station HUA-G3, showed a relatively large decrease in aquifer storage (fig. 7). This station is collocated with one of the City of Kingman's production wells, as well as an observation well (well B-22-16 28BAD, fig. 6). Groundwater levels at the observation well dropped about $14 \mathrm{ft}$ from 2009 to 2019. Lastly, 4 stations near Truxton Wash in the southeast part of the basin showed no change (TXT-BR2) or showed small decreases in storage (TXT-W1, TXT-W2, TXT-W3). Station TXT-BR2 is on bedrock, where aquifer storage changes are expected to be minimal, and small decreases at the other stations likely reflect the absence of large flows in Truxton Wash.

Together, the measurable changes in aquifer storage, which are consistent with changes in water level, and knowledge about pumping and recharge generally indicate unconfined aquifer conditions. In confined aquifers, changes in storage are generally very small, and result from the compressibility of the aquifer and water stored within. These small storage changes cannot be detected with the repeat microgravity method. Although specific yield (the ratio of a volume of water that a given mass of saturated soil or rock will yield by gravity to the volume of that mass) can be estimated using the repeat microgravity method in some situations where stations are collocated with monitoring wells, in the Hualapai Valley Basin storage changes were either too small (HUA-G2, TXT-WX) for accurate estimation, or the underlying assumptions were invalid (HUA-G4, where a pumping-induced cone of depression invalidates the infinite-slab approximation used to convert gravity change to storage change).

Tillman and others $(2011,2012)$, using satellite data to estimate basin-scale groundwater discharge by vegetation for the Basin and Range Physiographic Province of Arizona, indicated phreatic evapotranspiration along several washes and along the shoreline of Lake Mead. Subsequent spatial analysis by Garner and Truini (2011) showed that bank storage and soil moisture were the most likely sources of water for this vegetation. The amount of groundwater discharge through evapotranspiration from the alluvial basins in the study area is considered negligible.

\section{Groundwater Budget}

An annual groundwater budget, quantifying volumes of water flowing into and out of the Hualapai Valley Basin alluvial aquifer was presented in Garner and Truini (2011). The water budget presents basin-wide mean fluxes that are based on conditions observed in 2007-08 except for natural aquifer recharge from precipitation, which was calculated as a long-term mean for 1940-2008. The rate of natural aquifer recharge from precipitation was calculated using a physically based distributed model that calculated surface energy and surface mass flux in a grid (Flint and Flint, 2007a, 2007b). The natural-discharge rate was assumed to be equal to the natural-recharge rate - alteration of the naturaldischarge or natural-recharge rates by groundwater pumping during the period of calculation was assumed to be negligible.

\section{Predevelopment}

A predevelopment water budget describes the long-term steady-state condition that existed prior to any human development of groundwater resources. The predevelopment water budget used here is based on the work of Garner and Truini (2011). 


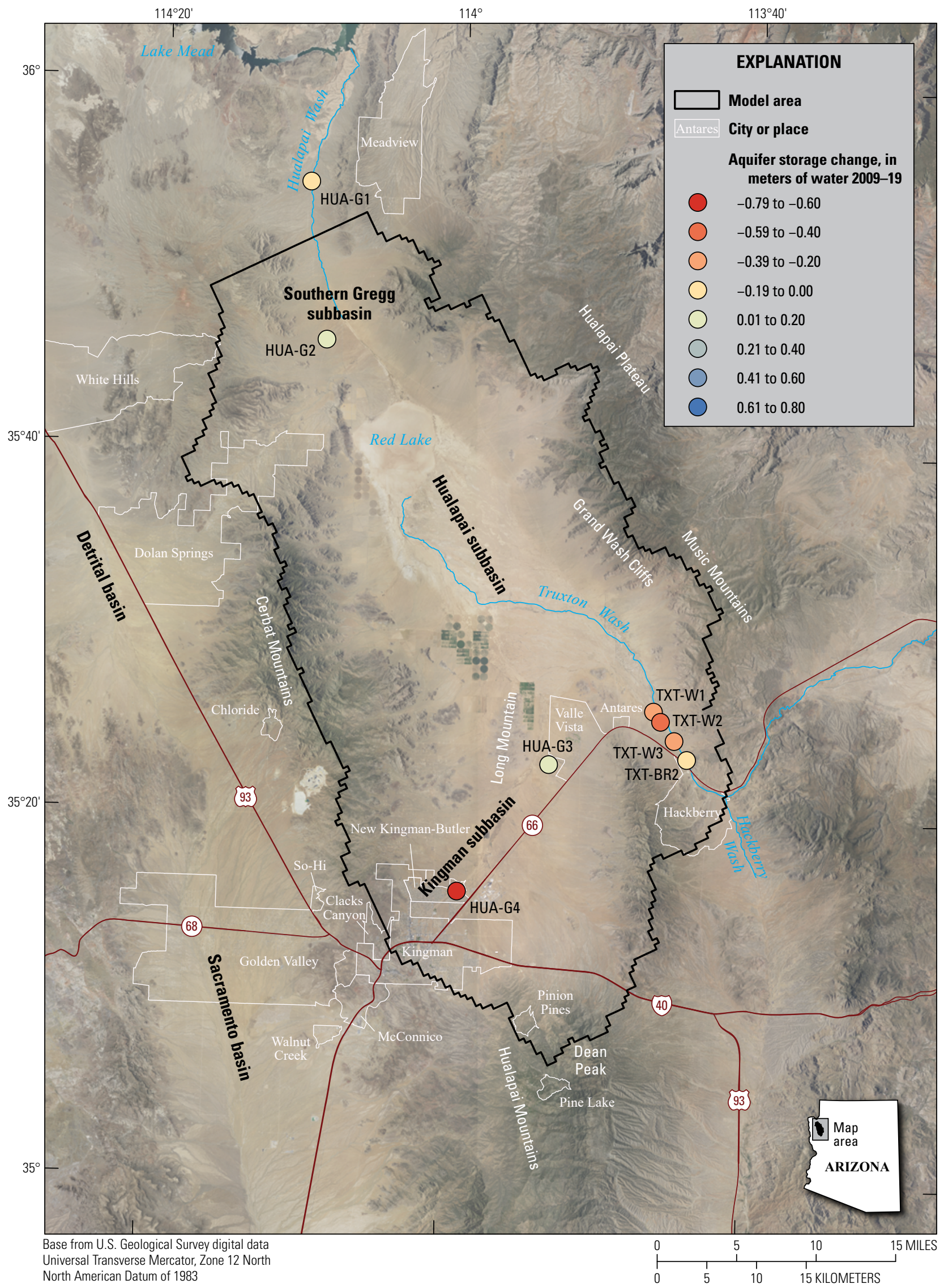

Figure 7. Map showing repeat microgravity monitoring locations and gravity change, converted to equivalent meters of water using the infinite-slab approximation, from 2009 to 2019, in the Hualapai Valley Basin, Mohave County, Arizona (data from Kennedy and Bucci, 2021). 
Owing to low precipitation and high evapotranspiration rates, the predevelopment natural-recharge rate in Hualapai Valley Basin was small relative to other groundwater basins in Arizona (Freethey and Anderson, 1986; Tillman and others, 2011). Natural aquifer recharge from precipitation was estimated at 5,700 acre-ft/yr, which was less than 1 percent of the estimated total precipitation $(610,000$ acre-ft/yr).

Predevelopment natural discharge from the Hualapai Valley Basin was mainly to the Colorado River and consisted of a minor component to the atmosphere through groundwater evapotranspiration from a limited area of phreatophytic plants (plants typically with a deep root system). Predevelopment groundwater budgets have no groundwater storage change (Healy and others, 2007) — predevelopment natural discharge rates were equal to recharge rates (table 1).

\section{Postdevelopment}

Garner and Truini (2011) calculated that close to 90 percent of the water withdrawn from Hualapai Valley Basin was used for municipal and domestic water supplies in 2007-08, chiefly in and around the City of Kingman (table 2). Groundwater used for industry such as mining or manufacturing was negligible. No other classifications of water use, including agriculture, were identified at that time. Of the estimated 9,800 acre-ft/yr of groundwater withdrawn, about 4,200 acre-ft/yr was estimated to return to aquifers through incidental recharge (recharge through seepage from unintended sources) using assumptions from other studies in comparable areas (Nishikawa and others, 2004). Discharge of effluent from septic-system drain fields accounted for nearly 70 percent of this incidental recharge, and the rest came from leaking water-supply pipes and infiltration of treated effluent from the City of Kingman Wastewater Treatment Plant (the latter is included as incidental recharge for the purposes of this water budget).

Since 2007-08, the largest increase in groundwater discharge has come in the agricultural sector. In 2014, 8,000 acre-ft of irrigation pumping first occurred. Irrigation pumping increased to 23,000 acre- $\mathrm{ft}$ in 2015, 32,000 acre-ft in 2016, and 35,000 acre-ft in 2017 (Read and Tadayon, 2021). In 2018 agricultural pumping decreased to 17,000 acre-ft, but this is presumed to be a temporary, 1 -year reduction in agricultural pumping owing to changes in land ownership. Municipal pumping decreased a few hundred acre-feet from 2010 to 2012 and has climbed steadily since. In 2017, 7,843 acre-ft of groundwater was pumped for municipal uses, almost entirely near the City of Kingman (Shannon Summers, Floodplain Programs Manager, Mohave County Development Services, written commun., 2018).
Table 1. Predevelopment groundwater-budget values for the Hualapai Valley Basin, Mohave County, Arizona, from Garner and Truini (2011).

[Groundwater-budget values are in acre-feet per year; $<$, less than; - , no data]

\begin{tabular}{lcc}
\hline \multicolumn{1}{c}{ Water-budget component } & \begin{tabular}{c} 
Inflow to aquifer \\
\multicolumn{1}{c}{ Natural recharge }
\end{tabular} & $\begin{array}{c}\text { Outflow from } \\
\text { aquifer }\end{array}$ \\
\hline $\begin{array}{l}\text { Mountain-block recharge } \\
\text { Named ephemeral stream- } \\
\text { channel recharge }\end{array}$ & 4,400 & - \\
$\begin{array}{l}\text { Other ephemeral stream- } \\
\text { channel recharge }\end{array}$ & 600 & - \\
$\begin{array}{l}\text { Underflow } \\
\text { Natural discharge to Lake } \\
\text { Mead or Colorado River }\end{array}$ & 400 & - \\
\hline Total & 1300 & 5,700 \\
\hline
\end{tabular}

${ }^{1}$ Underflow occurs where Truxton Wash enters Hualapai Valley Basin.

\section{Previous Models}

Tillman and others (2013) developed a single-layer, preliminary numerical groundwater-flow model with uniform cell bottom elevations to simulate past hydrologic conditions of the Hualapai, Sacramento, and Detrital Valleys. Model development included estimates of municipal and domestic water use, incidental recharge associated with such use, and spatially distributed recharge rates derived from a concurrently developed Basin Characterization Model (BCM) (Flint and Flint, 2007a). The model simulates predevelopment steadystate conditions prior to the construction of Hoover Dam in 1935 and transient conditions through 2010. The model was created to serve as a repository for this information and to estimate values of hydraulic aquifer properties through manual and automated calibration processes. The model was also used to test conceptual models of groundwater recharge (Tillman and others, 2013).

ADWR commissioned a study to estimate rates of groundwater depletion and number of years of available groundwater that remain for the basins of northwest Arizona (Matrix New World, 2019). The study extended the simulation period of the existing USGS model (Tillman and others, 2013) by estimating existing water use between 2011 and 2018 and implementing projections of future agricultural development provided by ADWR. The purpose was to simulate present and future hydrologic conditions based on estimates of current and projected water use. 
Table 2. Groundwater-budget values for the Hualapai Valley Basin, Mohave County, Arizona.

[Table includes values from previous studies for comparison and is adapted from Garner and Truini (2011). Acre-ft/yr, acre-feet per year; CWS, community water supplier; ET, evapotranspiration; maf, millions of acre-feet; SSD, self-supplied domestic; WWTP, wastewater treatment plant; <, less than; —, not applicable]

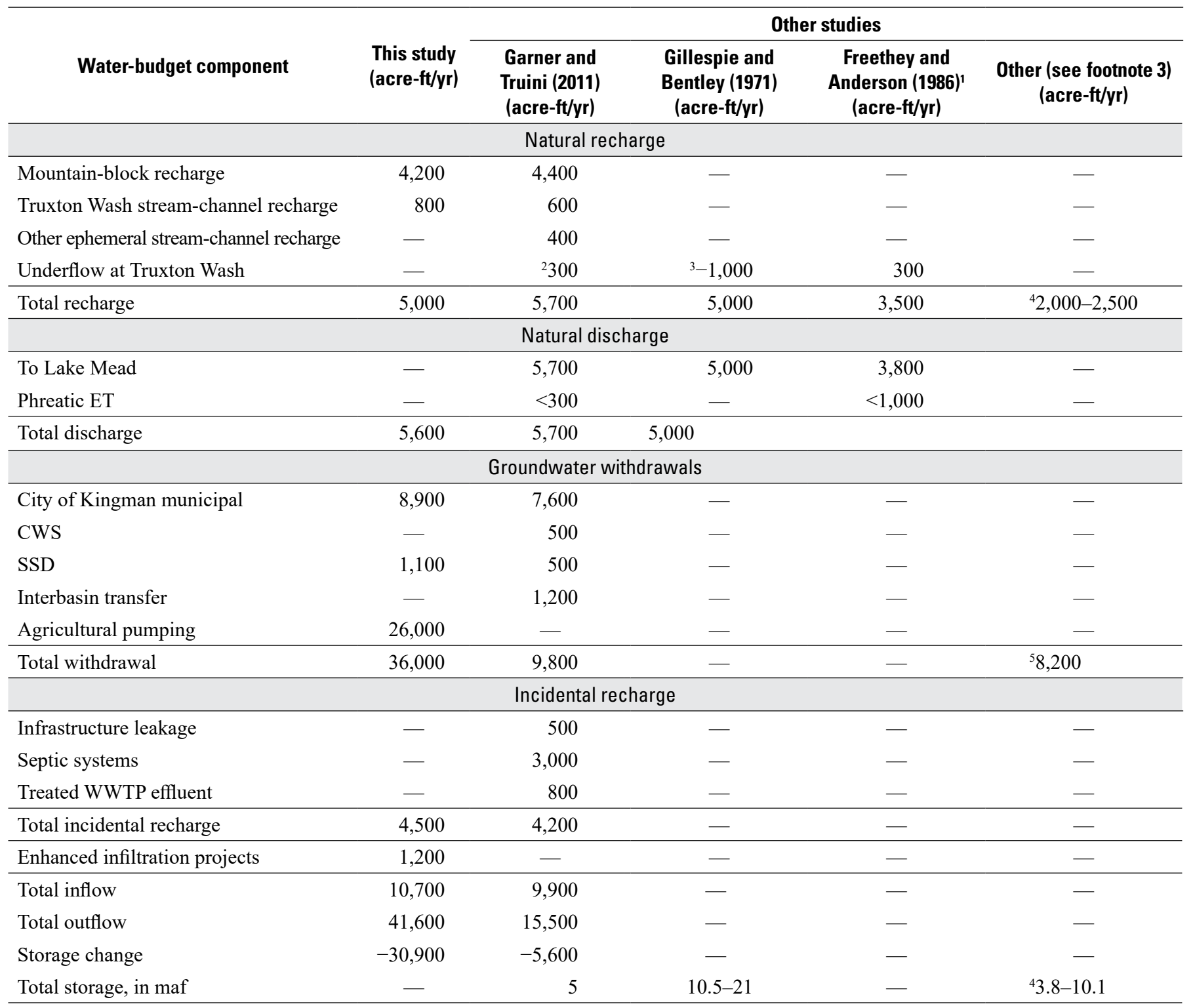

${ }^{1}$ Data are predevolpment values obtained from unpublished tabular data. Plates in report show only qualitative ranges of values.

${ }^{2}$ From Freethey and Anderson (1986) pre-development conditions, as there are insufficient data to calculate a current-condition value.

${ }^{3}$ Negative value indicates basin outflow, rather than inflow, because of large Truxton Canyon pumping withdrawals in the 1960s.

${ }^{4}$ Ivanich and Conway (2009).

${ }^{5}$ Tadayon (2005), value as of year 2000 . 


\section{Simulation of Groundwater Flow}

HVHM uses MODFLOW-NWT version 1.2 to solve the groundwater flow equation (Niswonger and others, 2011). MODFLOW-NWT is a Newton formulation of the MODFLOW-2005 program that is intended to solve problems involving drying and rewetting nonlinearities associated with the simulation of unconfined groundwater flow. Standard MODFLOW packages including recharge $(\mathrm{RCH})$, well (WEL), drain (DRN), upstream weighting (UPW), basic (BAS6), and discretization (DIS) are used to specify model properties and boundary conditions. The generalized minimum residual solver is implemented with little deviation from default settings.

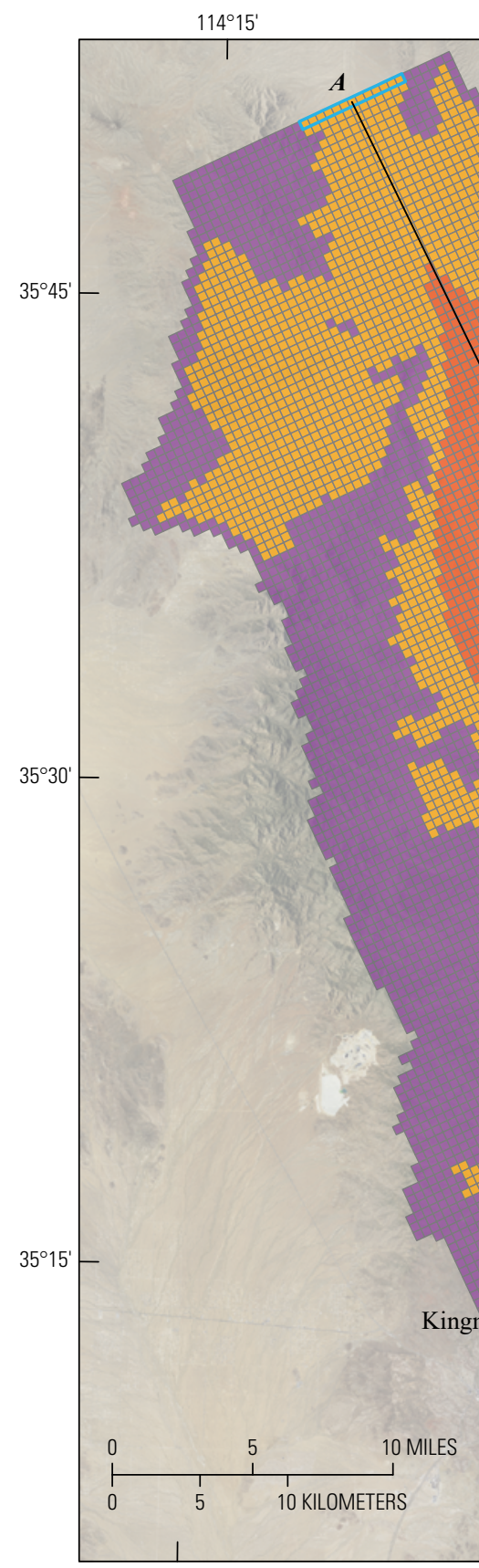

Base from U.S. Geological Survey digital data Universal Transverse Mercator, Zone 12 North North American Datum of 1983
Development of HVHM began with the existing preliminary USGS model as a starting point (Tillman and others, 2013). Some HVHM inputs, like pre-2011 groundwater withdrawal rates and incidental recharge, were resampled from the preliminary model grid and temporal discretization scheme to those of HVHM. Other aspects of the model, including basin geometry and extent of hydrogeologic units, were applied to the HVHM grid from the original data source (Truini and others, 2012). The model archive for this study is available as a data release (Knight, 2021).

Uncertainties in model parameters and outputs are represented using a Bayesian uncertainty framework (Fienen and others, 2013). Bayes' rule combines a prior distribution of parameters with an evaluation of the likelihood of observation data given those parameters to produce a posterior distribution of parameters.

Prior uncertainty is reduced through history matching, and what uncertainty remains in the posterior parameter estimates cascades to uncertainty in the simulated forecasts.

\section{Spatial and Temporal Discretization}

The HVHM grid (fig. 8) is a single layer of 174 rows and 100 columns consisting of 500-m by 500-m orthogonal cells of varying thickness. Multiple layers were implemented in early development of HVHM, but the additional complexity was generally not supported by known vertical distributions of aquifer properties.

Some locations exist around the edge

Figure 8. Map showing the Hualapai Valley Hydrologic Model grid and material property zones. Cross section $A-A^{\prime}-A^{\prime \prime}$ is shown in figure 9. DRN refers to the "drain" package used in the MODFLOW model.

\section{EXPLANATION}

\section{Material property zone}

Mountain bedrock

Medium to coarse basin-fill alluvium

Fine basin-fill alluvium

DRN boundary condition cells

WEL boundary condition cells

${\underline{A \quad A^{\prime}}}^{\prime}$ Line of section 
of the basin-fill alluvium where groundwater-level observations are from wells that appear to be seated in bedrock underlying the alluvium, but measurements are sparse. The additional complexity did not appear to enhance the model's ability to produce the forecasts of interest.

The model grid is rotated 25 degrees counterclockwise around the upper left corner. The active model area includes all model cells within the Hualapai Valley Basin. The basin is defined by topographic divides along the Cerbat Mountains to the west and the Grand Wash Cliffs and Music Mountains to the east. The Hualapai Valley Basin includes the Kingman and Hualapai subbasins which are separated by Long Mountain and a subsurface bedrock high. Of the 10,845 active cells, 3,924 represent mountain bedrock and 6,921 represent basin-fill alluvium. Cell top elevations represent land surface elevation, and cell bottoms are set to either bedrock elevation beneath basin-fill alluvium or a maximum simulated depth beneath land surface. Maximum simulated depth beneath land surface is $1500 \mathrm{~m}$ in basin-fill alluvium and $100 \mathrm{~m}$ in mountain bedrock (fig. 9). Maximum cell depth for basin-fill alluvium is based on the presence of a large halite body in the Hualapai subbasin (Faulds and others, 2016).

The simulation period of HVHM consists of one predevelopment steady-state stress period and 221 transient historical and forecast stress periods. The steady-state stress period simulates mean hydrologic conditions prior to 1935 . In steadystate simulations, inflows are equal to outflows and no change in storage occurs. Following the steady-state stress period, the model simulates historical transient conditions using 16 stress periods 5 years in length from 1935 through 2015, and 4 stress periods 1 year in length through 2018. Model inputs of water use and incidental recharge were resampled from the previous model (Tillman and others, 2013) to yearly rates and then intersected and averaged to the historical stress periods of the current model. The forecast period consists of 201 stress periods, 1 year in length, that simulate conditions through 2079.

\section{Boundary Conditions and System Stresses}

Natural recharge was simulated using the results of a SoilWater Balance (SWB) model (Westenbroek and others, 2010) created for HVHM. The SWB model was used primarily to produce realistic spatial distributions of groundwater recharge based on the conceptual model outlined above. Gridded daily precipitation and temperature data (PRISM Climate Group, 2020), hydrologic soil properties (Natural Resources Conservation Service, 2020), and overland flow directions were transferred to the model grid and used to simulate daily transient recharge from January 1, 1981, to December 31, 2018. The simulation period of the recharge model was dictated by availability of gridded precipitation and temperature data in the PRISM database. The SWB model requires input of hydrologic soil and vegetation properties organized by combinations of land-cover and soil types. Only two land-cover types were defined in HVHM: mountain bedrock and basin-fill alluvium. The basin-fill alluvium land-cover type combines both fine grain and medium to coarse materials shown in figure 8. Model cells representing mountain bedrock were assigned a higher ratio of direct runoff to infiltration, a lesser root depth, and a lower maximum infiltration rate than the basin-fill alluvium. Simulated recharge is limited to the model cells representing the outer margins of the alluvial basins and mountain bedrock. The central parts of the basins were inactivated in the SWB model, and the mountain bedrock was assigned a very low minimum rate of recharge to maintain model stability. Previous studies have shown that regional models are generally insensitive to precise spatial distributions of recharge (Anderson and Freethy, 1995; Tillman and others, 2014). The SWB model parameters, which are available in the model archive (Knight, 2021), were manually adjusted until results of annual mean simulated recharge (total volumetric flow and relative spatial distribution) generally aligned with the conceptual model. The

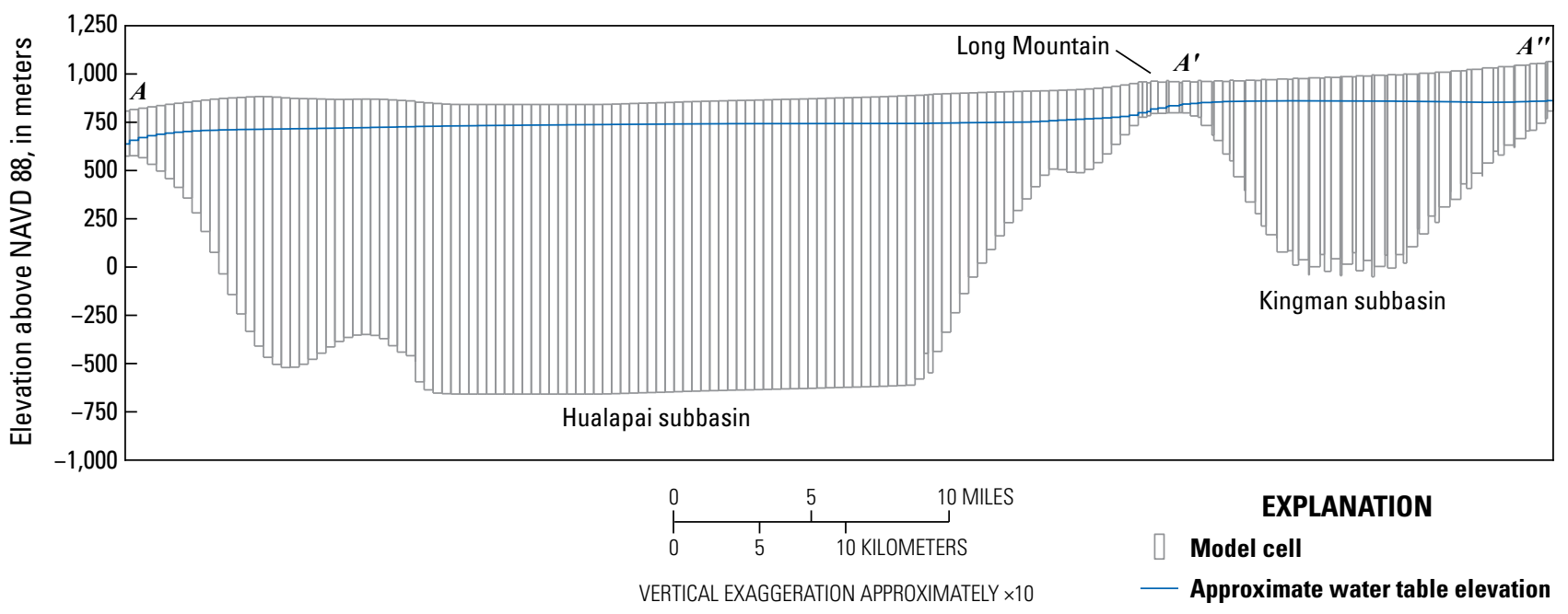

Figure 9. Cross section of line $A-A^{\prime}-A^{\prime \prime}$ from figure 8. Blue line represents approximate water table elevation. Note steep hydraulic gradient between subbasins east of Long Mountain (fig. 8). Figure is scaled to approximately 10x vertical exaggeration. 
simulated long-term mean recharge rates (fig. 10) were carried forward from the end of the SWB model simulation to the end of HVHM simulation. For stress periods prior to 1981, the long-term mean recharge rate was increased or decreased proportional to the variation in simulated recharge rates of the preliminary model (fig. 11).

Inflows from Truxton Wash are simulated as specified flux boundary conditions using MODFLOW WEL package. The conceptual model specifies an annual mean input to the groundwater system of 800 acre-ft/yr from surface and subsurface flows of Truxton Wash. This volumetric flow was divided evenly among the 29 model cells intersected by the National Hydrography Dataset flowline (U.S. Geological Survey, 2020a) representing the main channel of the upper reaches of Truxton Wash (fig. 12) and is held constant through steady-state and transient stress periods.

HVHM simulates groundwater outflow from the north end of the Hualapai subbasin through

Figure 10. Model showing mean annual simulated recharge applied to each model cell, in meters per day. Gray model cells represent inactive model cells. White model cells within the Hualapai Valley Hydrologic Model represent areas of zero simulated recharge.
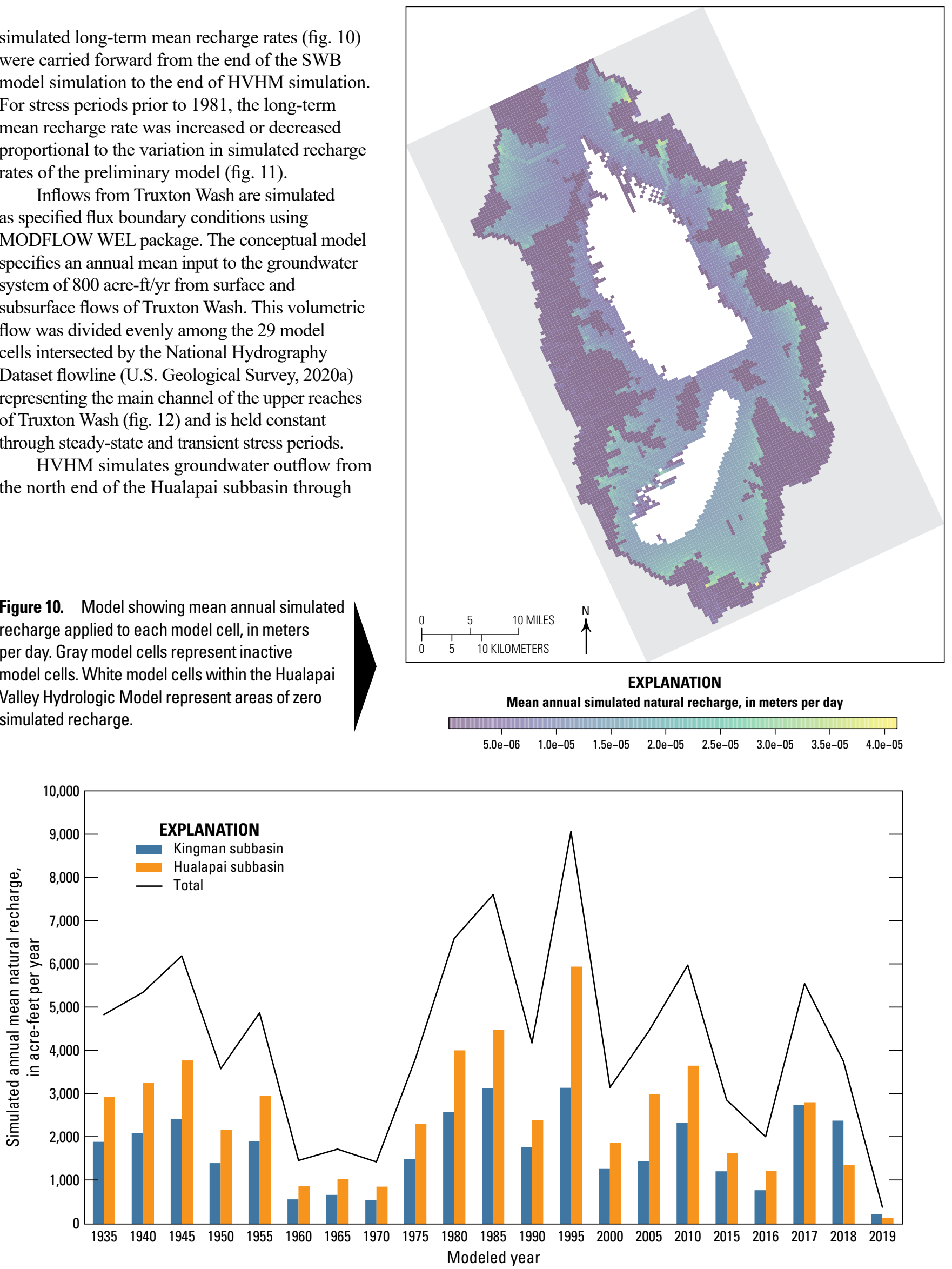

Figure 11. Graph showing the simulated annual mean natural recharge for Kingman and Hualapai subbasins and the total annual mean natural recharge for both subbasins, in acre-feet per year. 


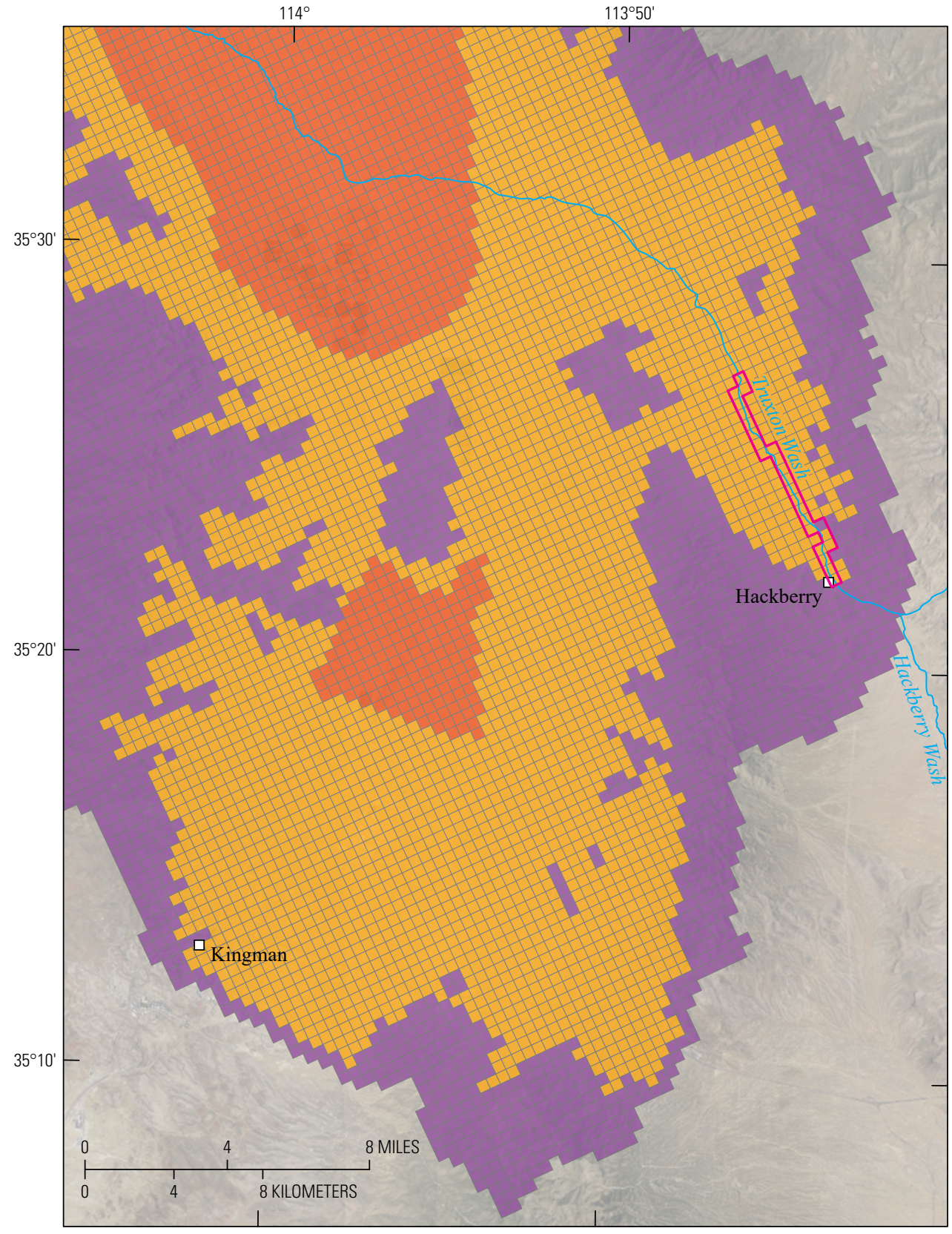

\section{EXPLANATION}

Material property zone

Mountain bedrock

Medium to coarse basin fill

Fine basin fill

Truxton Wash inflow cells
Figure 12. Map of southeast Hualapai Valley Basin Model cells simulating inflows from Truxton Wash. head-dependent flux boundary conditions implemented with the MODFLOW DRN package. Model cells representing basin-fill alluvium in row 1 (the northernmost row) are assigned drain elevations equal to the underlying bedrock elevations, which range from $1,700 \mathrm{ft}$ near the center of the channel to over $2,600 \mathrm{ft}$ at the edges. This row of cells crosses a local bedrock elevation high defining the northern extent of the subsurface geometry of the Hualapai subbasin (fig. 13). The model grid does not extend to Lake Mead because the land surface and bedrock dip steeply from this point down to the lake surface, which has historically fluctuated between approximately 1,100 and $1,200 \mathrm{ft}$, well below the bedrock elevation at the model boundary (Bureau of Reclamation,
2020). Steep hydraulic gradients and thin saturation can create model instability, so the edge of the subsurface basin geometry was selected as a convenient cut-off location.

Simulated groundwater withdrawals for municipal and self-supplied domestic (SSD) use are adapted from the preliminary groundwater model (Tillman and others, 2013) by transferring withdrawal locations to the new model grid and resampling transient withdrawal rates to the new stress period scheme. Municipal well locations were treated as point locations and intersected directly to the HVHM model grid (fig. 14). Municipal pumping, mainly in the City of Kingman area, decreased nearly $300 \mathrm{acre}-\mathrm{ft} / \mathrm{yr}$ from 2010 to 2012 and then increased over 600 acre-ft/yr to 7,843 acre-ft 

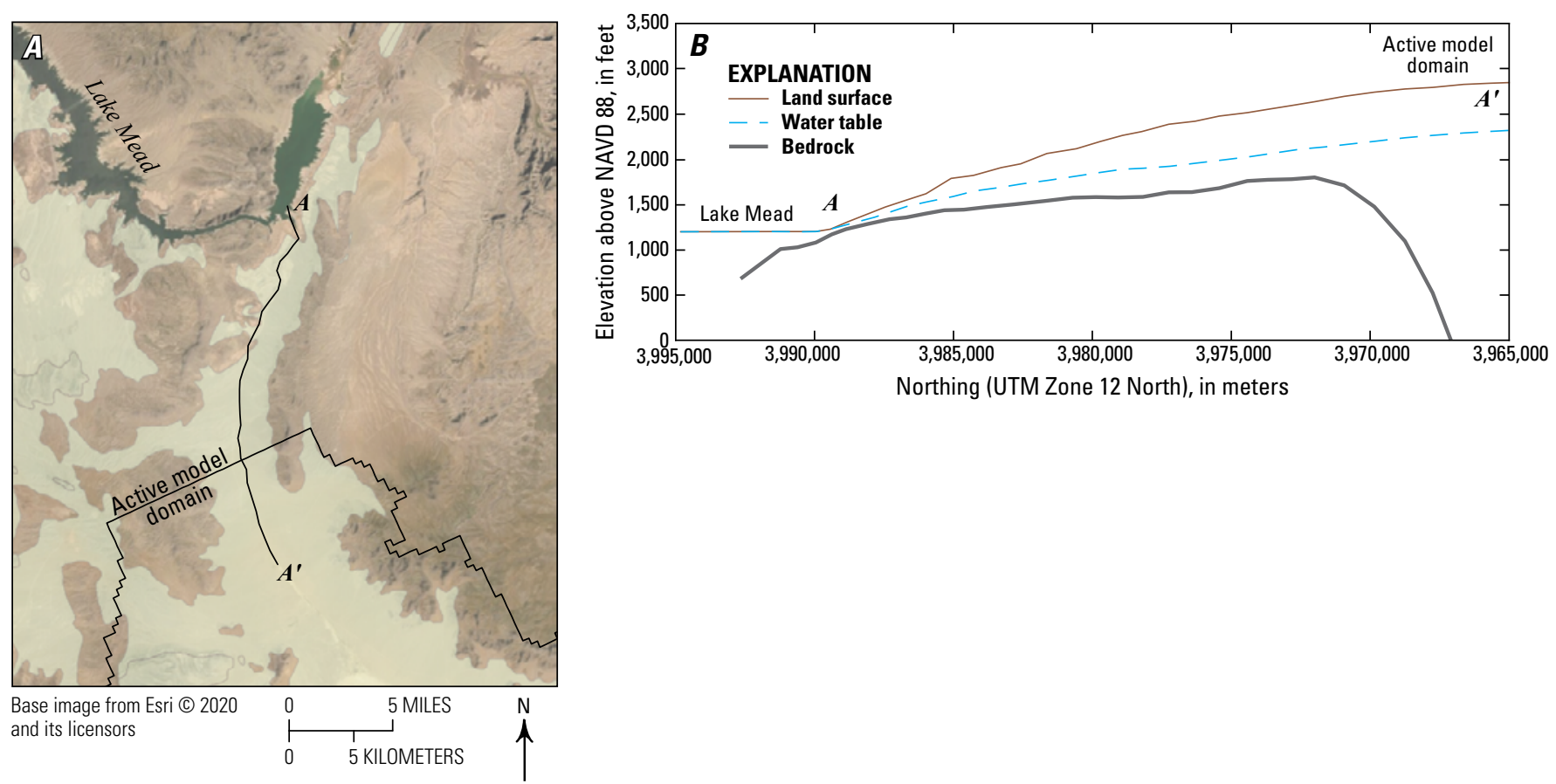

Figure 13. Satellite image $(A)$ of the north part of the Hualapai Valley Hydrologic Model and conceptual cross-sectional view $(B)$ across the north boundary of Hualapai Valley Hydrologic Model along Hualapai Wash to Lake Mead.
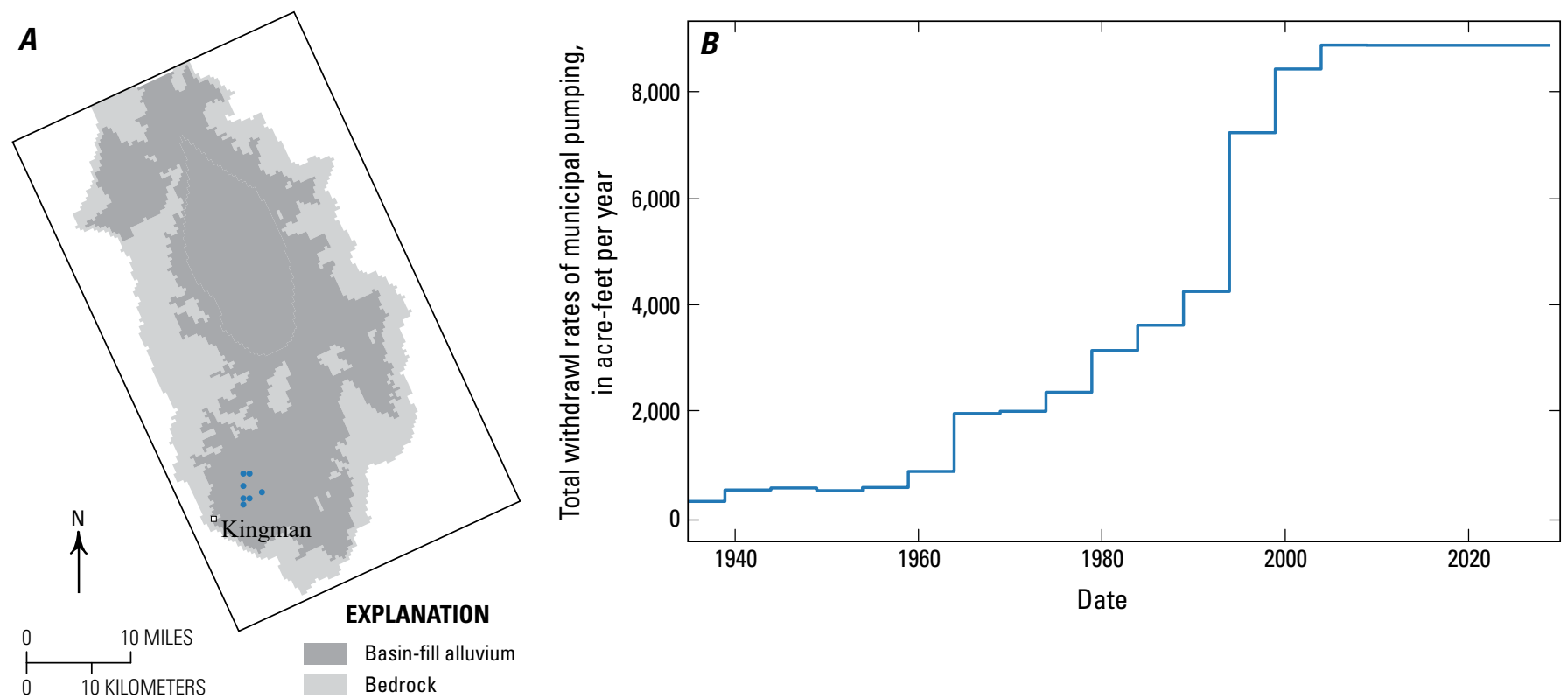

Figure 14. Map $(A)$ of Hualapai Valley Hydrologic Model area showing simulated municipal pumping locations (blue circles) and graph $(B)$ showing total withdrawal rates of municipal pumping. 
in 2017 (City of Kingman, written commun., 2020; table 3). SSD withdrawals in the preliminary model were assigned on a cell-by-cell basis and are not representative of individual wells. To transfer the spatially varying rates of SSD use to the HVHM grid, centroids were extracted as point objects from cells containing SSD withdrawals in the preliminary model and surrounded with a 500-m radius buffer to create a polygon shapefile of closely packed circles. These circles were intersected to the smaller, rotated cells of the HVHM grid and withdrawal rates from each circle were distributed to the intersected HVHM model cells on the basis of the percentage of the circle area intersected by each cell. The result is a similar spatial distribution of SSD withdrawal rates with nearly the same total volumetric flow rate as the preliminary model (fig. 15). SSD withdrawal rates are interpolated to the new model stress periods through the year 2010, and the last withdrawal rates are carried forward from 2010 to the end of model run.

Agricultural water use is simulated in HVHM from 2015 through the end of the simulation. Simulated withdrawal rates for years 2015-2018 are based on annual estimates of water use from satellite data and field verification (Read and Tadayon, 2021). The USGS Arizona Water Science Center estimated 8,000 acre-ft of agricultural pumping in 2014; 23,000 acre-ft in 2015; 32,00 acre-ft in 2016; and 35,000 acre-ft in 2017 (Read and Tadayon, 2021). In 2018 , agricultural pumping decreased to 17,000 acre-ft, but this is
Table 3. Municipal groundwater pumping in the Hualapai Valley Basin for years 2010-2017.

[Data from City of Kingman, written commun., 2020]

\begin{tabular}{ccc}
\hline Year & $\begin{array}{c}\text { Groundwater pumped, in } \\
\text { billion gallons }\end{array}$ & Acre-feet \\
\hline 2010 & 2.45 & 7,504 \\
2011 & 2.45 & 7,509 \\
2012 & 2.35 & 7,221 \\
2013 & 2.40 & 7,360 \\
2014 & 2.43 & 7,443 \\
2015 & 2.46 & 7,555 \\
2016 & 2.37 & 7,283 \\
2017 & 2.56 & 7,843 \\
\hline
\end{tabular}

thought to be a temporary, single-year pumping reduction. Polygon shapefiles containing withdrawal rates for each year of existing data were intersected to the model grid and model cells were assigned a portion of the withdrawal rate based on the percentage of polygon area intersected by the cell.
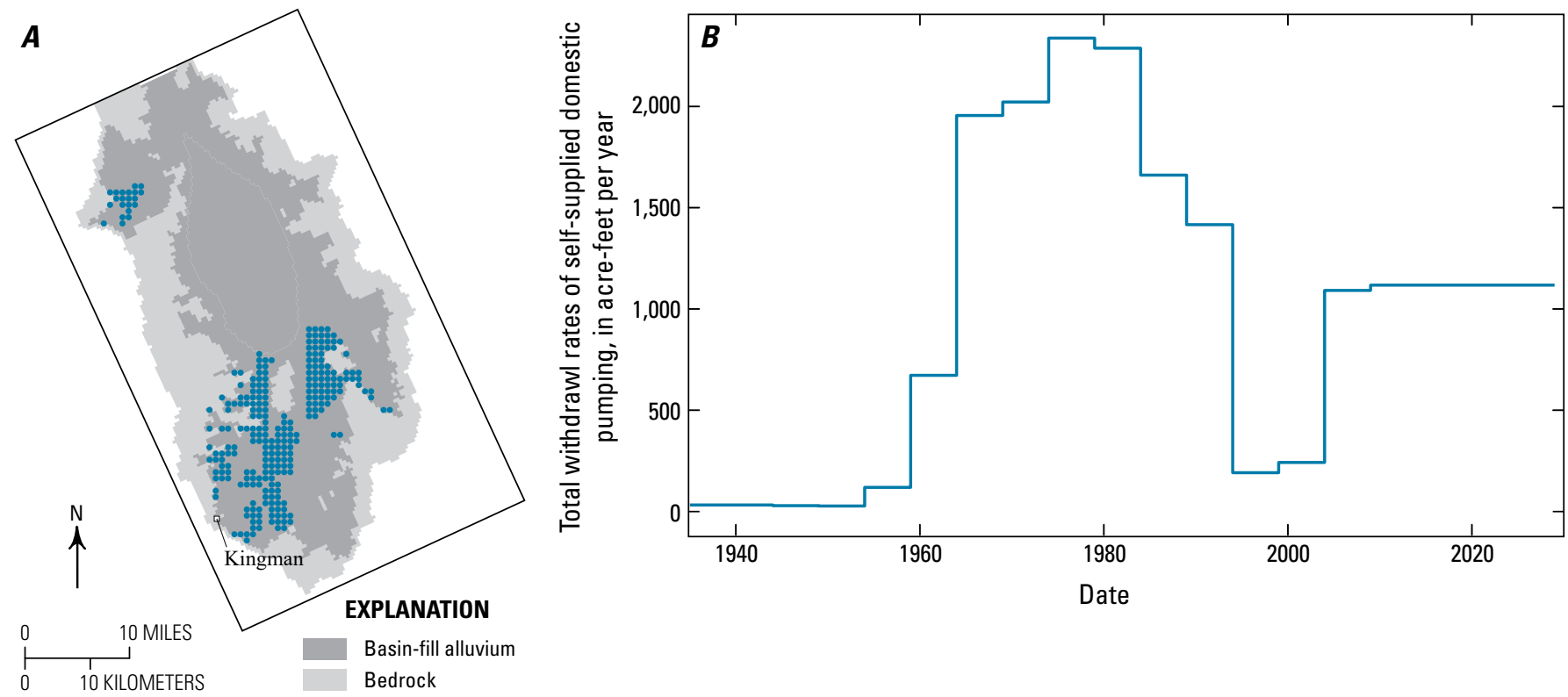

Figure 15. Map $(A)$ of Hualapai Valley Hydrologic Model area showing simulated self-supplied domestic (SSD) locations and graph $(B)$ showing total withdrawal rates of SSD pumping. 


\section{Hualapai Valley Basin Withdrawal and Recharge Scenarios}

Withdrawal rates for years 2019-2029 are based on a scenario provided by Mohave County. The scenario provides an estimate of cultivated acreage and total annual withdrawal in years 2019, 2024, and 2029 for each of the major agricultural landowners (table 4). Projected total acreage increases from 14,090 in 2019 to 44,360 acres by 2029 , and total withdrawal rates increase from 26,060 to 128,800 acre- $\mathrm{ft} / \mathrm{yr}$, respectively (table 4). Approximately 75 percent of the future developed acreage and withdrawals are projected to occur in the Hualapai subbasin. Parcel ownership maps provided by Mohave County were intersected to the model grid as polygon shapefiles, and intersected cells deemed most likely to be cultivated were manually selected to satisfy the total acreage projections for 2024 and 2029 (figs. 16, 17). Annual withdrawal rates for each group were linearly interpolated between the scenario withdrawal rates specified for 2019, 2024, and 2029. For each ownership group the interpolated annual withdrawal rate was applied to model cells proportional to the parcel acreage intersected to each cell.
Table 4. Agricultural groundwater pumpers and projected annual withdrawals (in acre-feet).

\begin{tabular}{cccc}
\hline $\begin{array}{c}\text { Farm ID } \\
\text { (figure 17) }\end{array}$ & $\begin{array}{c}\text { Water demand } \\
\text { estimate in 2019 }\end{array}$ & $\begin{array}{c}\text { Water demand } \\
\text { estimate in 2024 }\end{array}$ & $\begin{array}{c}\text { Water demand } \\
\text { estimate in 2029 }\end{array}$ \\
\hline 1 & 0 & 36,720 & 64,260 \\
2 & 22,550 & 26,400 & 30,250 \\
3 & 2,430 & 4,050 & 13,500 \\
4 & 0 & 6,372 & 11,151 \\
\hline 5 & 0 & 2,808 & 4,914 \\
\hline 6 & 1,080 & 1,728 & 3,024 \\
\hline 7 & 0 & 972 & 1,701 \\
\hline Total & 26,060 & 79,050 & 128,800 \\
\hline
\end{tabular}

Incidental recharge likely occurs from leaks in the municipal water supply system, from septic system drain fields, and from wastewater treatment plant effluent. Preliminary model inputs were transferred to HVHM in the same manner as SSD withdrawals described above, and volumetric rates from the final preliminary model stress period were carried forward through the end of HVHM simulation (fig. 18).
Figure 16. Map showing model cells simulating agricultural withdrawals beginning in 2019, 2024, and 2029.

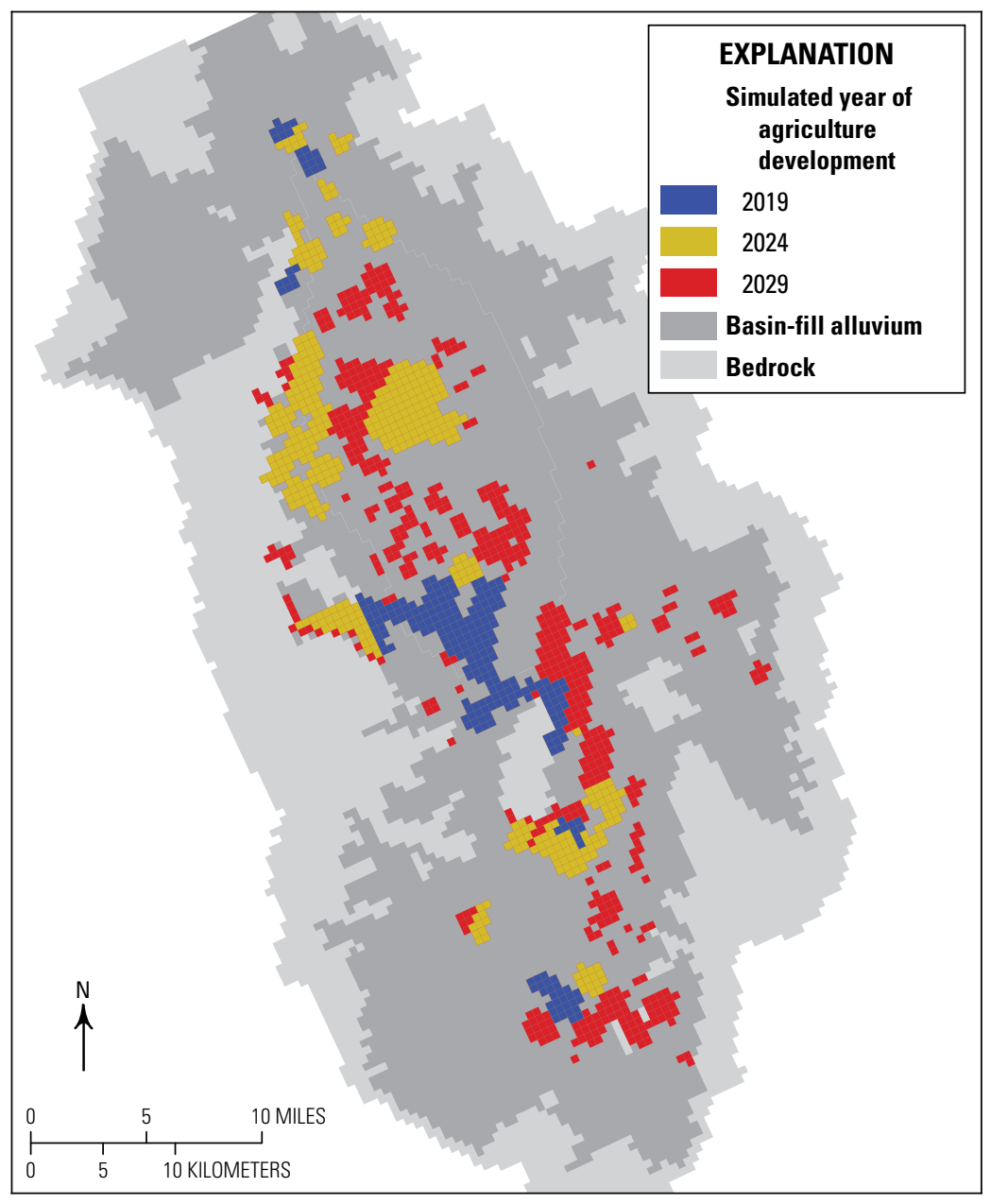



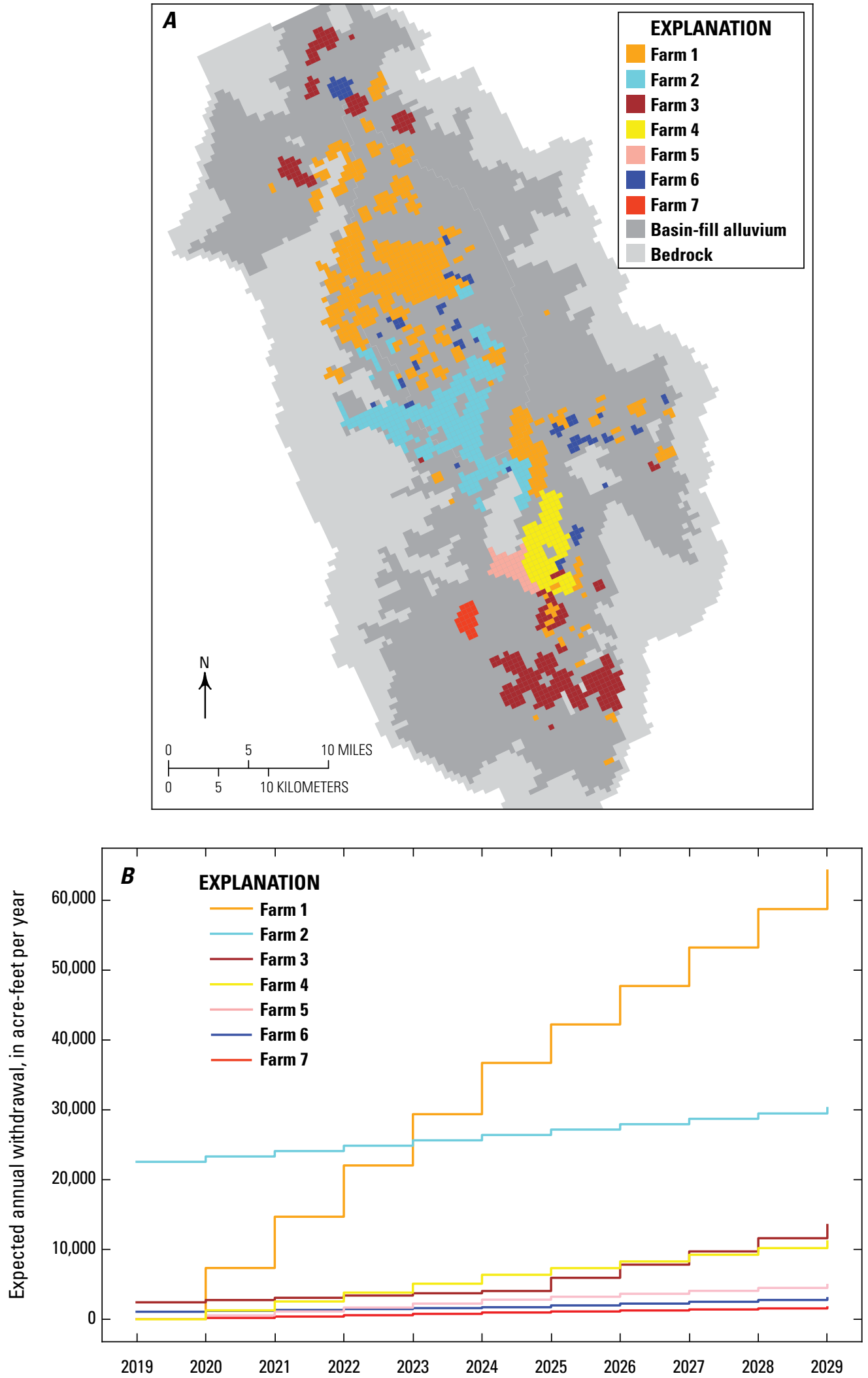

Figure 17. $\operatorname{Map}(A)$ of model and land-ownership groups and graph $(B)$ showing expected annual withdrawals by each group, in acre-feet per year. Map and graph are based on parcel maps and tables provided by Mohave County. 


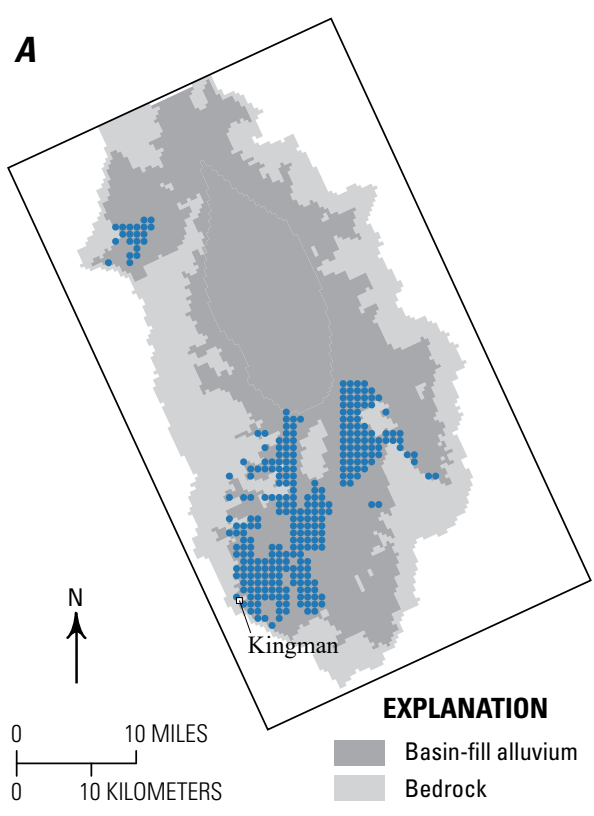

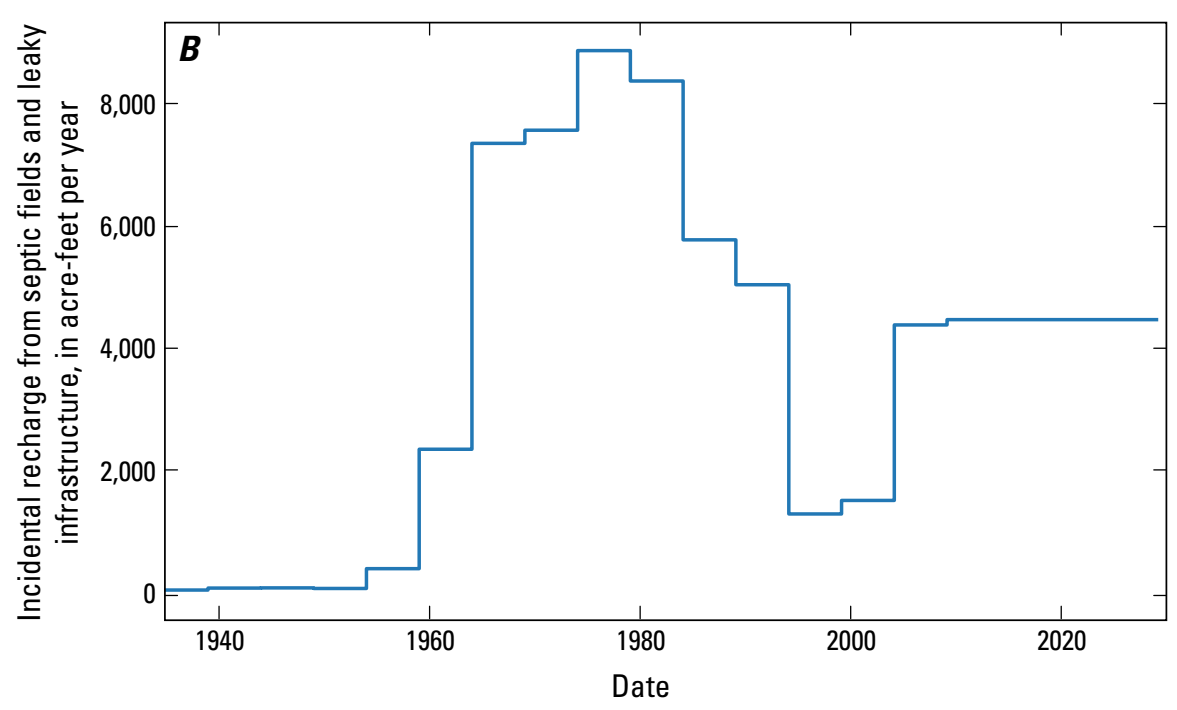

Figure 18. $\operatorname{Map}(A)$ of simulated locations and graph $(B)$ showing total rates of incidental recharge from septic fields and leaky infrastructure, in acre-feet per year.
Mohave County and the City of Kingman are attempting to replenish groundwater storage in the Kingman subbasin through enhanced infiltration projects in and around the City of Kingman (fig. 18). There are currently two completed projects, a recharge well at the City of Kingman Wastewater Treatment Plant and a small infiltration basin at Monsoon Park, a community park in the City of Kingman, at the western edge of the Kingman subbasin (locations 1 and 2 in fig. 19 and table 5, respectively). An additional nine enhanced infiltration projects are proposed for the central and southern parts of the Kingman subbasin, and individual capacities of these infiltration projects range from about 80 to about 1,700 acre-ft/yr for a total additional capacity to the proposed infiltration network of 3,915 acre-ft/yr. The recharge well at the wastewater treatment plant currently recharges an estimated 1,200 acre-ft/yr. The Monsoon
Park infiltration project site recharges an additional estimated $10 \mathrm{acre}-\mathrm{ft} / \mathrm{yr}$ of stormwater runoff annually. Total network infiltration capacity (existing and planned recharge capacity) at buildout is estimated by Mohave County to be 5,125 acre-ft/yr (table 5).

Enhanced infiltration project sites are intersected as point locations to the HVHM grid and implemented as specified flux boundary conditions using the MODFLOW WEL package. Specified fluxes reflect estimates provided by Mohave County. The two existing project sites begin simulating recharge to the model in the stress period representing year 2019 and continue through the end of model simulation. The nine proposed infiltration projects are activated only in the enhanced recharge scenario in the stress period representing year 2020 and run through the end of enhanced recharge scenario simulation.

Table 5. Estimated recharge capacity of existing and planned infiltration projects

[acre-ft/yr, acre-feet per year; - , no data]

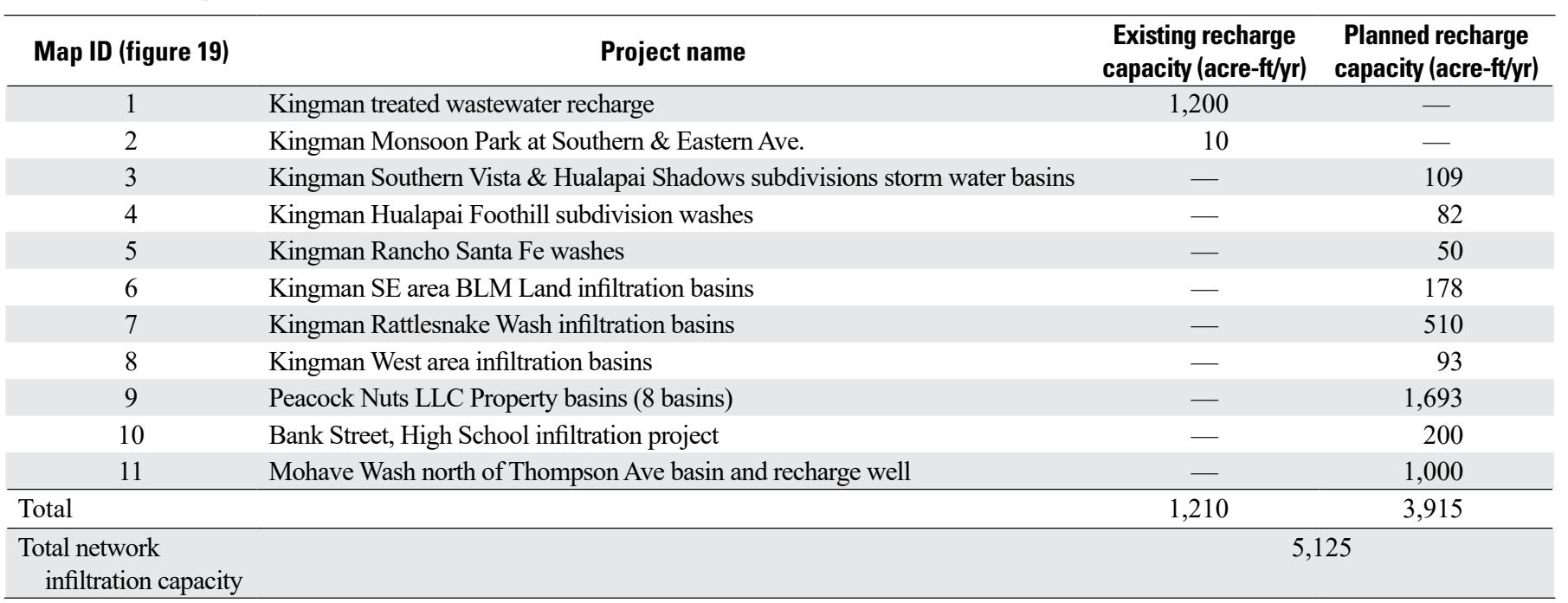




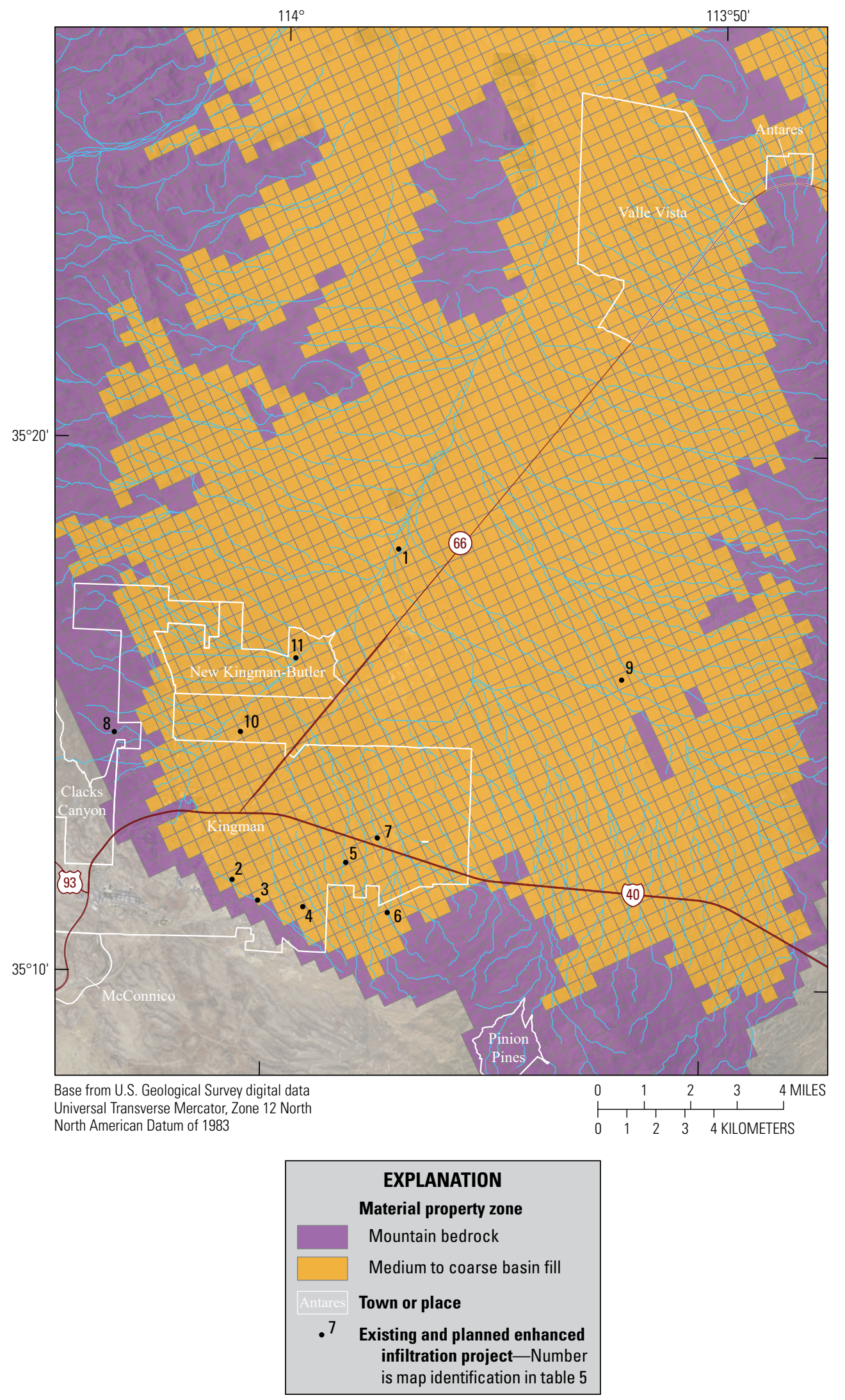

Figure 19. Map of southern part of the Hualapai Valley Hydrologic Model showing existing and planned enhanced infiltration project locations in the Kingman subbasin. 


\section{Model Parameter Estimation and Uncertainty Quantification}

Model parameter estimation and uncertainty quantification were performed using the iterative ensemble smoother PESTPPIES, included in the PEST++ version 4.3.16 software suite (Welter and others, 2015; White, 2018), in conjunction with open-source python packages FloPy (Bakker and others, 2016) and PyEMU (White and others, 2016). The combination of these software and tools allows much of the parameter estimation and uncertainty quantification workflow to be programmatically scripted, which provides transparency and reproducibility (White and others, 2020).

The iterative ensemble smoother (IES) algorithm is a relatively new approach to parameter estimation and uncertainty analysis and is available through the opensource PEST++ software suite. IES provides two important advantages over the more frequently used Gauss-LevenburgMarquardt (GLM) algorithm: reduced computational demand for highly parameterized models and accessible means to estimate uncertainty of forecasts that depend on a high number of parameters (White and others, 2020).

The IES algorithm substantially reduces the computational demand of parameter estimation for highly parameterized models by using a Monte Carlo simulation to approximate the relation between model inputs (parameters) and outputs (simulated equivalents of historical observations and forecasted conditions). This approximation allows the number of model runs required in each iteration of the parameter estimation process to be much fewer than the number of adjustable parameters. HVHM includes 75,586 adjustable parameters, and the parameter estimation process implemented for HVHM uses only 100 model realizations in each iteration of the algorithm to draw samples from distributions of these parameters, compare resulting distributions of model outputs to historical observations, and upgrade the estimated distribution of parameters on the basis of model fit to observations.

The IES approach provides the benefit of built-in uncertainty analysis. The result of the IES algorithm is an ensemble of models built with parameter values drawn from distributions informed by historical observations. The model realizations in this upgraded ensemble show similar success simulating historical conditions while using different parameter values and combinations of parameter values. This represents a level of uncertainty in aquifer properties that leads to a range of forecasted future conditions. The variability in future conditions produced by the ensemble provides an empirical estimate of forecast uncertainty without substantial additional analysis.

A high-dimensional parameter space is used to facilitate robust forecasts of groundwater-level elevations that retain an appropriate level of uncertainty. Model input uncertainty is represented by 75,586 parameters. Spatially distributed parameters are modified by multiplier parameters at multiple scales, from domain-wide global multipliers to grid-scale multipliers acting on individual cells. This multiscale approach to parameterization allows for different spatial scales of uncertainty to be represented
(McKenna and others, 2020). Appendix 2 contains a detailed description of the parameter estimation and uncertainty analysis workflow and options used in the implementation of PESTPP-IES.

\section{Prior Parameter Distribution}

The prior parameter distribution constructed for HVHM contains reasonable first estimates of mean parameter values and variances, and relations between parameters that are based on expert knowledge and previous modeling results. The parameter estimation process implemented with PESTPP-IES modifies the mean and variance of every adjustable parameter on the basis of model fit to observed groundwater level and drawdown observations. This results in a posterior parameter distribution that is used to forecast future hydrologic conditions. The prior and posterior parameter distributions are roughly analogous to initial and calibrated parameter sets of a calibration process undertaken in a regularized minimum-error-variance approach (Moore and Doherty, 2005).

Mean aquifer property values of the prior parameter distribution were assigned through a manual trial-and-error process of running the model with relatively uniform property values. The variances of these properties were defined in the prior parameter distribution by a suite of overlapping multiplier parameters that modify the base property value at different spatial and temporal scales. Global multipliers are single values applied domain-wide, pilot point multipliers are distance-weighted interpolations to each cell from surrounding pilot points spaced 10 cells apart, and grid scale multipliers are individually applied to each model cell. Geostatistical variograms define spatial covariance among groups of pilot point and grid-scale multiplier values. Table 6 presents a summary of the spatial and temporal scales at which these multiplier parameters modify the underlying aquifer properties in the parameter estimation process, the range of multiplier values affecting each property type, and the imposition of lower and upper limits on the effective property value (minimum and maximum absolute value, respectively) derived from the application of the multiplier parameters.

Temporally static, spatially distributed aquifer properties including horizontal hydraulic conductivity, specific yield, and specific storage are modified during parameter estimation by the combined effects of a domain-wide multiplier, a multiplier interpolated to each cell from surrounding pilot point locations, and a multiplier assigned to each individual model cell. Drain conductance properties are only estimated on the grid scale because there is only one short line of drain cells representing the northern outlet of Hualapai Valley Basin.

Hard upper and lower limits are assigned to each model property to prevent simulation of unrealistic property values resulting from the modification of base values by their associated multiplier parameter(s). For example, the effective simulated value of specific yield in the cell of a given model realization would be determined by multiplying the base value of 0.10 by 3 multiplier parameters: a domain-wide constant multiplier, a pilot point derived multiplier, and a grid scale 
Table 6. Aquifer property characteristics, mean prior parameter multiplier range, and absolute value range.

[X indicates implemented spatial scales and (or) temporal variation of parameters; $\mathrm{m} / \mathrm{d}$, meters per day; $\mathrm{m}^{-1}$, per meter; —, not applicable]

\begin{tabular}{|c|c|c|c|c|c|c|c|}
\hline \multirow[b]{2}{*}{ Aquifer property } & \multicolumn{5}{|c|}{ Multiplier parameters } & \multirow[b]{2}{*}{$\begin{array}{l}\text { Minimum } \\
\text { absolute } \\
\text { value }\end{array}$} & \multirow[b]{2}{*}{$\begin{array}{c}\text { Maximum } \\
\text { absolute } \\
\text { value }\end{array}$} \\
\hline & $\begin{array}{c}\text { Global } \\
\text { scale } \\
\text { multiplier }\end{array}$ & $\begin{array}{l}\text { Pilot point } \\
\text { multiplier }\end{array}$ & $\begin{array}{l}\text { Grid scale } \\
\text { multiplier }\end{array}$ & $\begin{array}{l}\text { Temporal } \\
\text { variation }\end{array}$ & $\begin{array}{c}\text { Lower } \\
\text { and upper } \\
\text { limits }\end{array}$ & & \\
\hline Horizontal hydraulic conductivity & $\mathrm{X}$ & $\mathrm{X}$ & $\mathrm{X}$ & - & $0.1-10.0$ & $1 \times 10^{4} \mathrm{~m} / \mathrm{d}$ & $100 \mathrm{~m} / \mathrm{d}$ \\
\hline Specific yield & $\mathrm{X}$ & $\mathrm{X}$ & $\mathrm{X}$ & - & $0.5-2.0$ & 0.01 & 0.30 \\
\hline Specific storage & $\mathrm{X}$ & $\mathrm{X}$ & $\mathrm{X}$ & - & $0.1-10.0$ & $1 \times 10^{7} \mathrm{~m}^{-1}$ & $1 \times 10^{3} \mathrm{~m}^{-1}$ \\
\hline Head-dependent flux boundary conductance & - & - & $\mathrm{X}$ & - & $0.1-10.0$ & - & - \\
\hline $\begin{array}{l}\text { Specified fluxes (groundwater withdrawals, } \\
\text { incidental and enhanced recharge) }\end{array}$ & - & - & $X$ & $X$ & $0.90-1.10$ & - & - \\
\hline
\end{tabular}

multiplier. Because each of those multiplier parameters are selected from a log normal distribution (as specified in the "Prior Parameter Distribution" section) between 0.5 and 2.0, an unconstrained application of the multiplier parameters from the upper limits of the prior parameter distribution could result in an effective simulated value anywhere between 0.0125 and 0.80 . Specifying a hard upper limit of 0.30 avoids simulating unreasonably high values of specific yield. Hard upper and lower limits were likewise imposed for effective simulated values of horizontal hydraulic conductivity and specific storage (table 6). Recharge flux in any given model cell is limited to a maximum of $4 \times 10^{-5}$ meters per day with a natural lower limit of 0 . Drain conductance values are not constrained more than the limits imposed by the grid scale multiplier parameter range from 0.1 to 10.0 .

Specified fluxes simulated with the WEL and $\mathrm{RCH}$ packages are parameterized spatially and temporally. Gridscale multipliers modify the specified WEL package fluxes in each model cell within the range of 0.9-1.1 and are held constant through the simulation period (table 6). A domainwide global multiplier selected for each stress period from within the same range compounds this variability and is applied uniformly to all specified WEL package fluxes. Spatially distributed recharge rate inputs are modified by multipliers interpolated from pilot point parameterization estimated for each stress period and a domain-wide global multiplier estimated for each stress period. The range of the pilot point and global multipliers is from 0.75 to 1.25 , reflecting substantial uncertainty with regards to spatial and temporal variability of natural recharge rates.

\section{Parameter Estimation with PESTPP-IES}

Parameter estimation was performed by a form of history matching in which an ensemble of model parameters, starting with the prior parameter ensemble, is propagated through a series of iterative upgrades to improve fit between model-simulated outputs and observed data.

The fit to observational data for each model realization in the ensemble is quantified by a sum of squared weighted residuals, or objective function $(\phi)$. The objective function is expressed as:

$$
\phi=\sum_{i=1}^{n}\left[\omega_{i}\left(s_{i}-o_{i}\right)\right]^{2}
$$

where:

$$
\begin{array}{cl}
n & \text { is the number of observations, } \\
\omega_{i} & \text { is the observation weight, } \\
s_{i} & \text { is the simulated value, and } \\
o_{i} & \text { is the observed value. }
\end{array}
$$

In PESTPP-IES the observed value in equation 1 is combined with additive measurement noise drawn from a specified range or derived from the observation weight. This creates an ensemble of observation realizations that are paired individually with parameter realizations for the iterative parameter upgrade process.

The objective function for HVHM compares observed groundwater levels and temporal changes in groundwater levels at 43 locations in Hualapai Valley to their simulated equivalents (fig. 20). Well locations and observation records were gathered from ADWR Groundwater Site Inventory database (ADWR, 2020) and USGS National Water Information System database (U.S. Geological Survey, 2020b); data from the USGS National Water Information System database (https://waterdata.usgs.gov/ nwis) can be accessed using the site numbers given in table 3.1. Only one observation location was allowed within any $3 \times 3$ cell area. Time series data from the two sources were merged and all measurements flagged as being affected by recent or nearby pumping were discarded. Time series data were smoothed using a rolling window mean of 10 years in early time (pre-2010), and 2 years in late time (2010 through 2018). This removed much of the transient noise while retaining the important trends expected to be matched by the model, such as long-term groundwater-level declines near Kingman municipal wells and recent short-term declines near recent agricultural developments. 


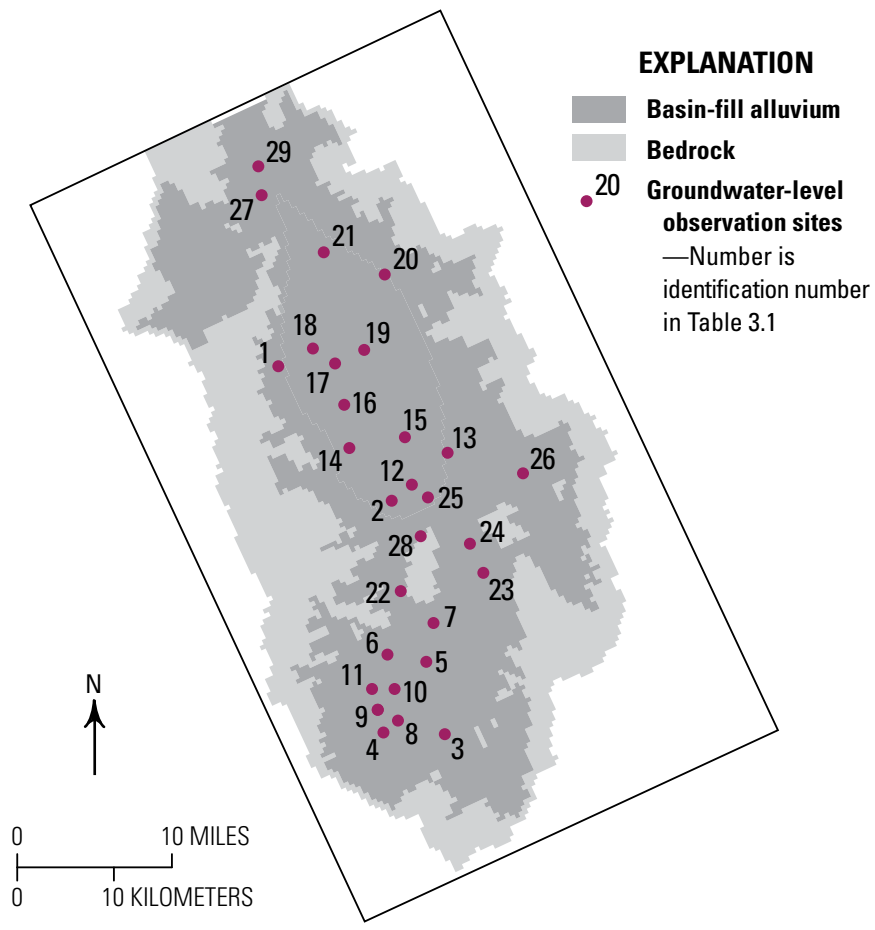

Figure 20. Map showing site locations of observed groundwater levels and drawdowns used for parameter estimation of the Hualapai Valley Hydrologic Model. See table 3.1 for summary of data at each site.
Target observations were created from smoothed observation values nearest the end of each stress period. Targets of temporal differences in groundwater levels were created for each location by calculating the difference between smoothed groundwater levels assigned to consecutive stress periods.

Groundwater-level observation weights were assigned on the basis of reported site altitude accuracy and subjective judgement of the site's importance to the modeling purpose (Doherty and Welter, 2010). Weights for groundwater-level observations were initially set as 1 divided by the site altitude accuracy, then multiplied by factor of $0,0.33,0.66$, or 1.0 to impose relative importance of observation time series at each site. Temporal difference observation weights were assigned a starting weight of 10 to account for scaling differences and to form an objective function that places importance on both absolute and changes in level observations. Temporal difference observations were then multiplied by factor of $0,0.33,0.66$, or 1.0 to impose relative importance of observation time series at each site. History matching with PESTPP-IES was run using 386 non-zero weighted groundwater-level observations and 233 non-zero weighted temporal difference observations. Prior data conflict, the condition of a nonzero weighted observation falling outside the range of simulated equivalents produced by the ensemble of models (Evans and Moshonov, 2006: Oliver, 2020), reduced these counts to 287 and 205, respectively (appendix 2 and table 3.1).

The parameter estimation algorithm of PESTPP-IES was run through 8 iterations requiring a total of 1,041 forward model runs (fig. 21A). An initial ensemble of 100 model realizations
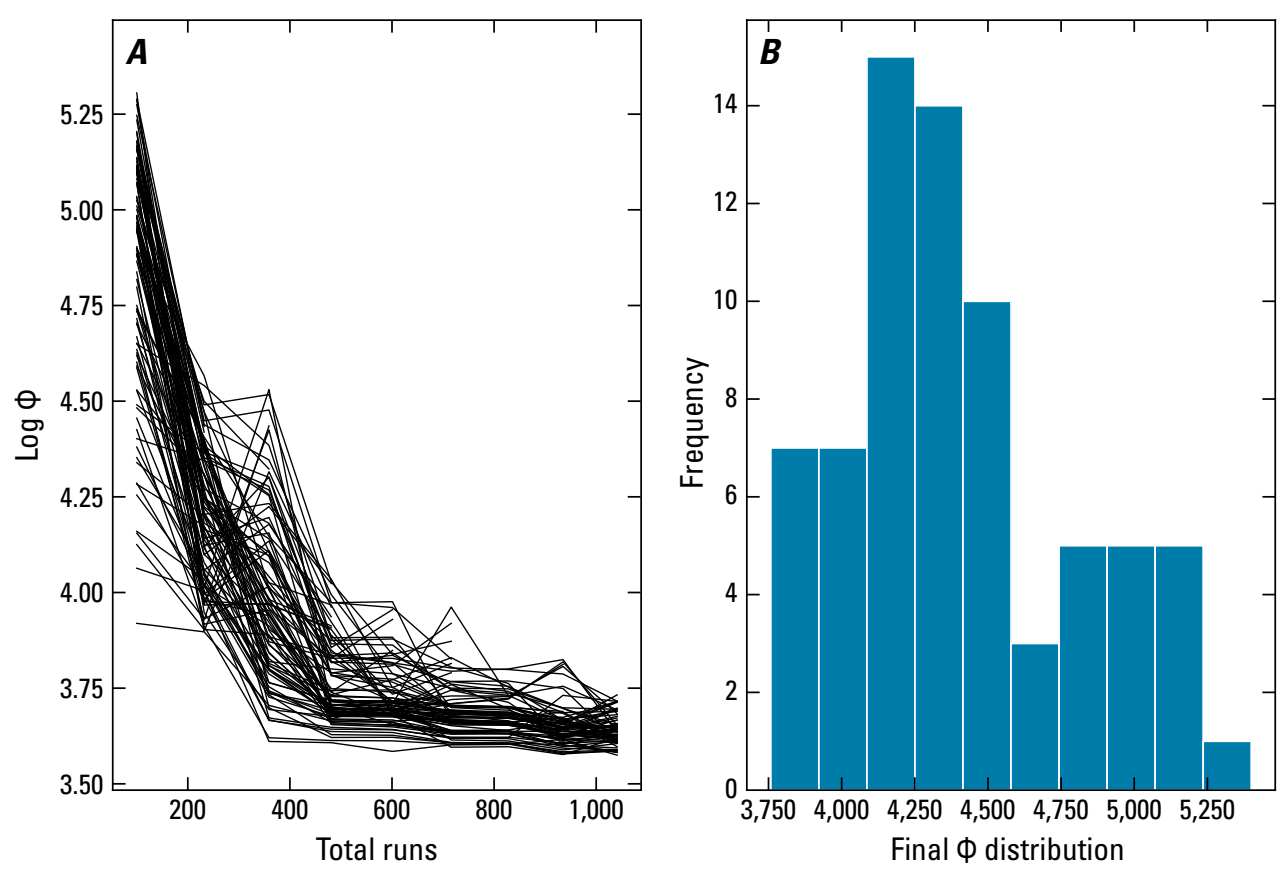

Figure 21. Graphs showing objective function reduction over 8 iterations $(A)$ and the posterior ensemble distribution $(B ; n=72)$ of objective function values. 
drawn from the prior parameter distribution was reduced to 72 realizations after dropping realizations in each iteration that simulated historical observations substantially worse than the mean of all realizations. Model fit to data was greatly improved from the prior distribution for non-zero weighted observations of both groundwater levels and temporal differences in groundwater levels (fig. 3.1). The output ensemble of 72 realizations was conditioned on the basis of expert judgement of generalized likelihood measures (Beven and Binley, 1992) to include only the 40 best-fit models (fig. $21 B$ ). The mean and variance for each of the 75,586 multiplier parameters in these 40 realizations constitute the posterior parameter distribution. Forecasted groundwater levels and drawdowns of future withdrawal and recharge scenarios presented in this report are produced by forward runs of these 40 model realizations.

\section{Posterior Parameter Distribution}

Effective simulated aquifer property values derived from the upgraded multiplier parameters in the posterior distribution are within reasonable ranges (table 7). Mean hydraulic conductivity of basin-fill alluvium is somewhat larger than estimated in the prior distribution, and mean specific yield is slightly larger. Mean values of drain conductance for the head-dependent flux boundary condition simulating the outflow point at the northern extent of the Hualapai subbasin decreased by about 30 percent compared to the prior distribution. Multiplier parameters applied to specified fluxes simulated in the WEL and $\mathrm{RCH}$ packages did not change substantially from the prior distribution. These parameters are relatively uninformed by historical observations compared to the horizontal hydraulic conductivity (HK) and specific yield (SY) datasets in MODFLOW. Including a distribution of these parameter values in the posterior distribution helps retain associated uncertainty in scenario forecast results.

Spatial distributions of HK and SY vary considerably between model realizations included in the posterior parameter distribution, even though the fit to observation data is similar (fig. 22). This illustrates the problem of non-uniqueness associated with any single set of parameters estimated on the basis of available historical observations, and it shows the importance of producing a range of physically realistic parameters in order to retain an appropriate level of uncertainty in forecast scenario results.

\section{Simulation of Transient Conditions}

The range of simulated hydraulic heads in the time series hydrographs produced by the posterior ensemble model realizations generally bracket historical hydraulic head observations at most of the 29 groundwater observation sites included in the model (appendix 1). Simulated hydraulic heads at the five sites nearest the City of Kingman (site numbers 4, $8,9,10$, and 11 on fig. 20) show good fit with the exception of early (pre-2010) observations at sites 9 and 10, and late observations (post-2010) at site 8. Model fit to data from observation sites is more mixed in the northern part of the Kingman subbasin. Simulated hydraulic heads at site 6 bracket all but the earliest measurements at that site, whereas simulated hydraulic heads are generally lower than historical observations at sites 5 and 7.

Simulated hydraulic heads are in close agreement to historical observations at site 22 west of Long Mountain, but simulated hydraulic heads at sites 23 and 24 are consistently higher and lower, respectively, compared to historical observations. The observed hydraulic gradient between these two sites is much steeper than simulated by the model.

Model fit to timeseries of observed historical hydraulic heads in the Hualapai subbasin is generally good. Simulated hydraulic heads at sites $2,12,13,14,17,25$, and 28 reflect observed declines in groundwater levels since the start of larger-scale agricultural development in 2015. At the north end of the Hualapai subbasin, historical observations are well matched at site 27 but simulated hydraulic heads are generally higher than historical observations at site 29. Similar to the model area west of Long Mountain, the model simulates a hydraulic gradient less steep than indicated by historical observations at the two sites.

Table 7. Aquifer property characteristics from base realizations of prior and posterior parameter distributions.

[HK, Dataset of hydraulic conductivity along rows; $\mathrm{m} / \mathrm{d}$, meter per day; $\mathrm{m}^{3} / \mathrm{m}^{3}$, cubic meter per cubic meter; $\mathrm{m}^{-1}$, per meter; $\mathrm{m}^{2} / \mathrm{d}$, square meter per day]

\begin{tabular}{lccc}
\hline \multicolumn{1}{c}{ Property } & Prior base realization & & \multicolumn{2}{c}{ Posterior base realization } \\
\cline { 2 - 4 } & Mean value & Mean value & Standard deviation \\
\hline Basin-fill HK $\left(\log _{10} \mathrm{~m} / \mathrm{d}\right)$ & 0.225 & 0.384 & 0.529 \\
Mountain HK $\left(\log _{10} \mathrm{~m} / \mathrm{d}\right)$ & -2.0 & -1.76 & 0.404 \\
Basin-fill specific yield $\left(\mathrm{m}^{3} / \mathrm{m}^{3}\right)$ & 0.10 & 0.132 & 0.043 \\
Mountain specific yield $\left(\mathrm{m}^{3} / \mathrm{m}^{3}\right)$ & 0.025 & 0.034 & 0.010 \\
Basin-fill specific storage $\left(\log _{10} \mathrm{~m}^{-1}\right)$ & -5.0 & -5.31 & 0.399 \\
Mountain specific storage $\left(\log _{10} \mathrm{~m}^{-1}\right)$ & -5.0 & -5.53 & 0.397 \\
Drain conductance $\left(\mathrm{m}^{2} / \mathrm{d}\right)$ & 50 & 35.2 & 9.39 \\
\hline
\end{tabular}


$\boldsymbol{A}$

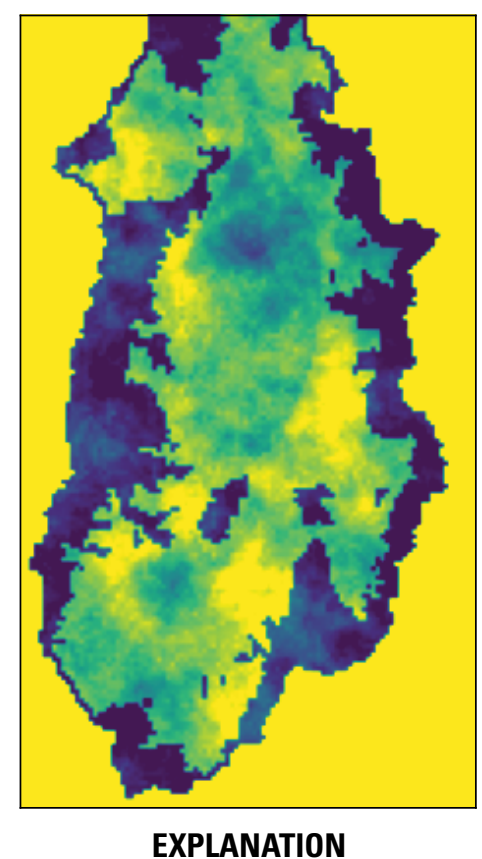

Hydraulic conductivity, in meters per day (log 10)

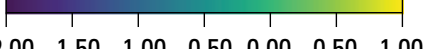

$-2.00-1.50-1.00-0.50 \quad 0.00 \quad 0.50 \quad 1.00$

$\boldsymbol{B}$

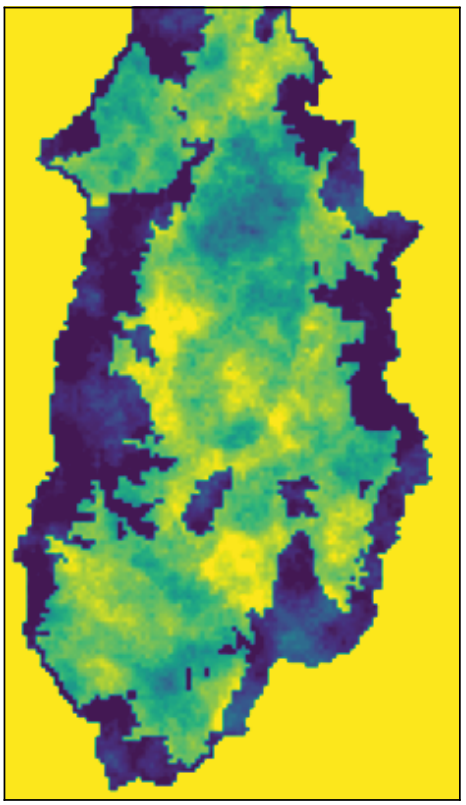

EXPLANATION

Hydraulic conductivity, in meters per day $(\log 10)$

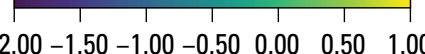

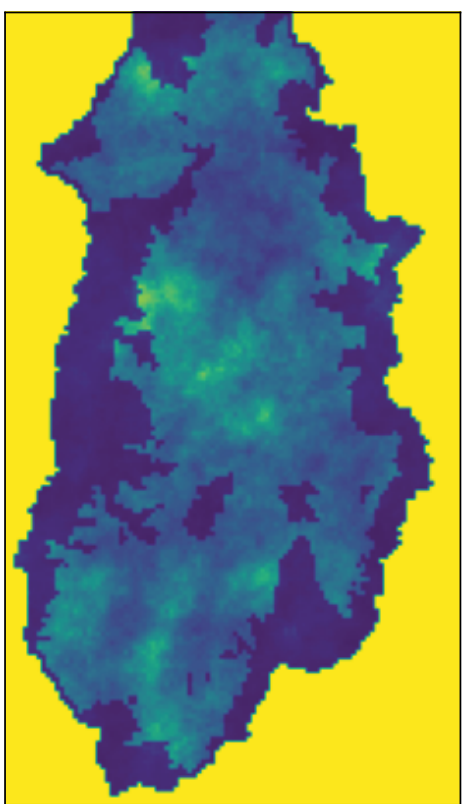

\section{EXPLANATION}

Specific yield, in $\mathrm{m}^{3} / \mathrm{m}^{3}$
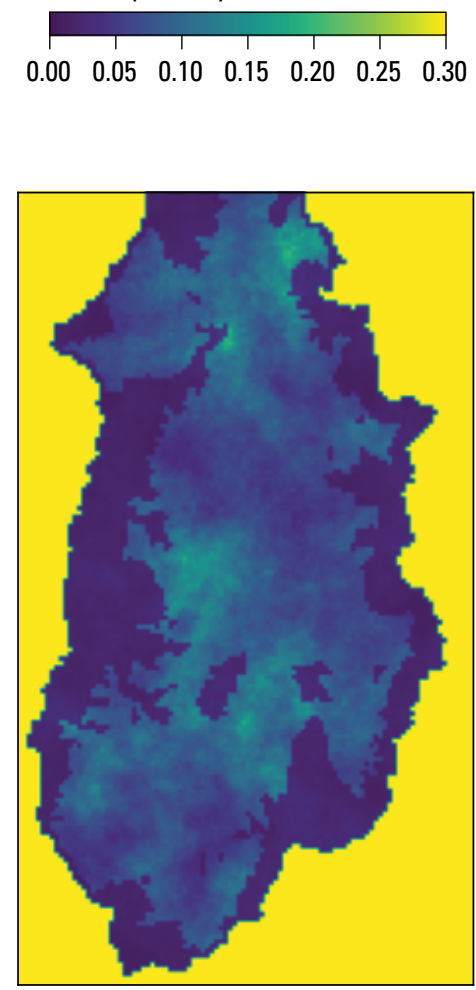

EXPLANATION

Specific yield, in $\mathrm{m}^{3} / \mathrm{m}^{3}$

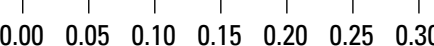

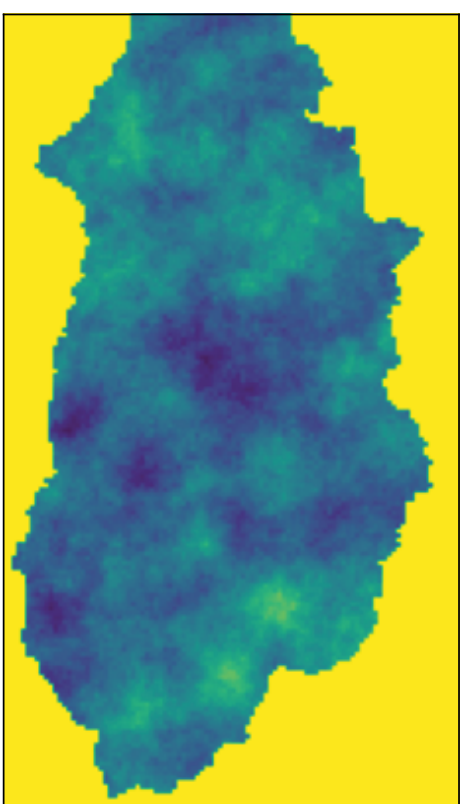

EXPLANATION

Specific storage, in $1 / \mathrm{m}(\log 10)$
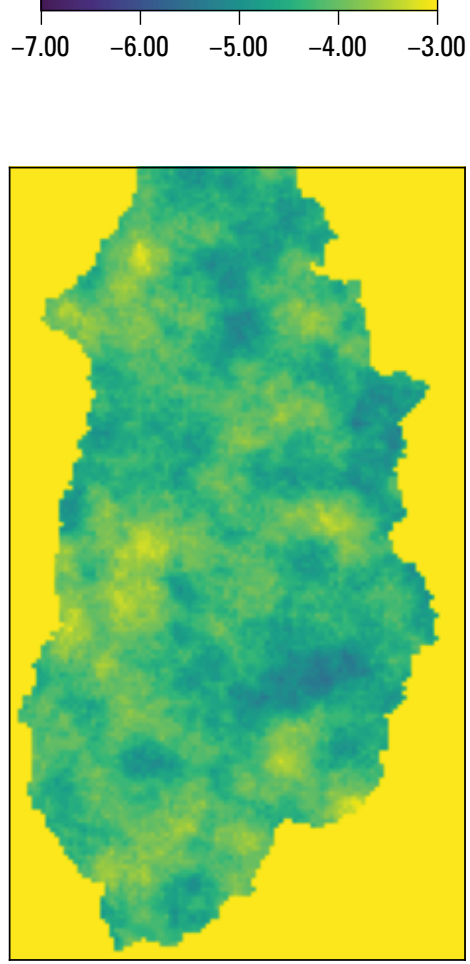

EXPLANATION

Specific storage, in $1 / \mathrm{m}(\log 10)$

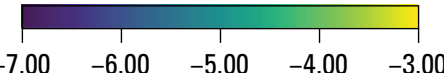

Figure 22. Two posterior ensemble model realizations, realization $13(A)$ and $80(B)$, of hydraulic conductivity, specific yield, and specific storage showing similar fit to historical observation data. 


\section{Simulation of Future Withdrawal and Enhanced Recharge Scenarios}

The future withdrawal scenario (table 4, figs. 16, 17) simulates substantial groundwaterlevel declines throughout the Hualapai Valley groundwater basin. Simulated drawdowns between years 2020 and 2050 and between years 2020 and 2080 are greatest near simulated current and future agricultural developments in the eastern and northern parts of the Kingman subbasin, and in the western and southern parts of the Hualapai subbasin. Lesser drawdowns are simulated in the northern and eastern extents of the Hualapai subbasin, and in the southern extent of the Kingman subbasin (fig. 23).

Simulated desaturation of the basin-fill aquifer above the shallow bedrock high east of Long Mountain occurs early in the forecast scenario, effectively disconnecting the two subbasins hydraulically. This occurs in all scenario realizations before 2050. Desaturation also occurs in model cells at the margins of the basin-fill aquifer. Simulated desaturation of model cells precludes the model from simulating the full rate of withdrawal specified in the forecast scenarios. Examination of the MODFLOW groundwater budget output reveals that net simulated outflows through the WEL package are less than specified by model input by approximately 1,000 acre-ft in year 2020, with the disparity increasing to approximately 15,000 acre-ft in year 2080 (fig. 24). Reduced simulated fluxes are clustered along the western margin of Hualapai subbasin, above the shallow bedrock high east of Long Mountain, and southeast of Kingman Fault (fig. 25; see fig. 1 for locations geographic features). Forecasted drawdowns presented in this report are the result of the simulated withdrawal levels, which are less than specified by model input.

Figure 23. Map views showing mean simulated drawdown for the final withdrawal scenario, standard deviation of drawdown, and uncertainty reduction of drawdown forecasts. $A$, Mean simulated drawdown in basin-fill alluvium model cells for the future withdrawal scenario produced by the posterior ensemble 2020 2050 and 2020-2080 model realizations. $B$, Standard deviation of simulated drawdown produced by the posterior ensemble model realizations of 2020-2050 and 2020-2080. C, Uncertainty reduction of drawdown forecasts gained from parameter estimation.
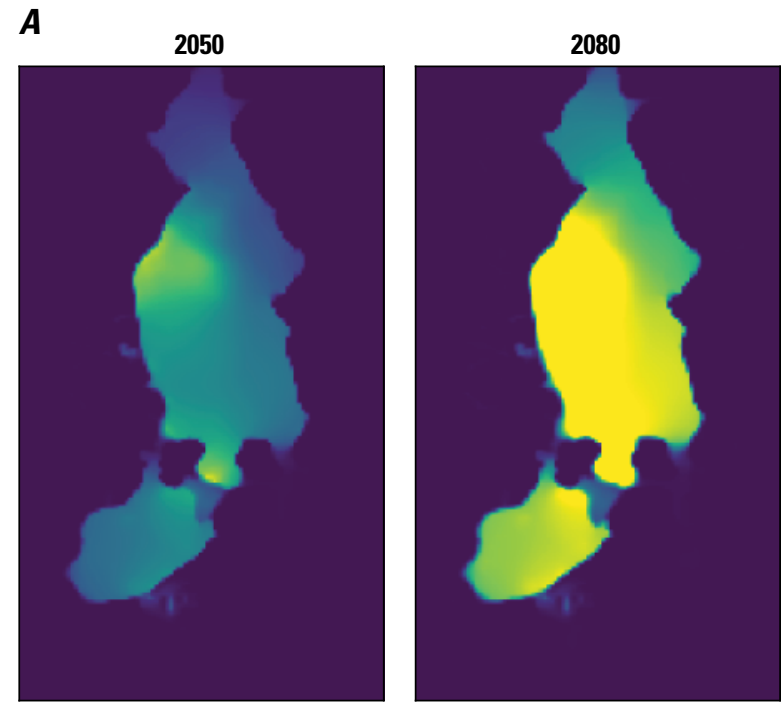

EXPLANATION

Mean drawdown from 2020 levels, in feet

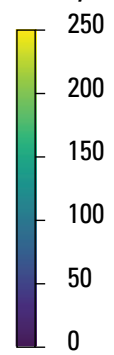

B
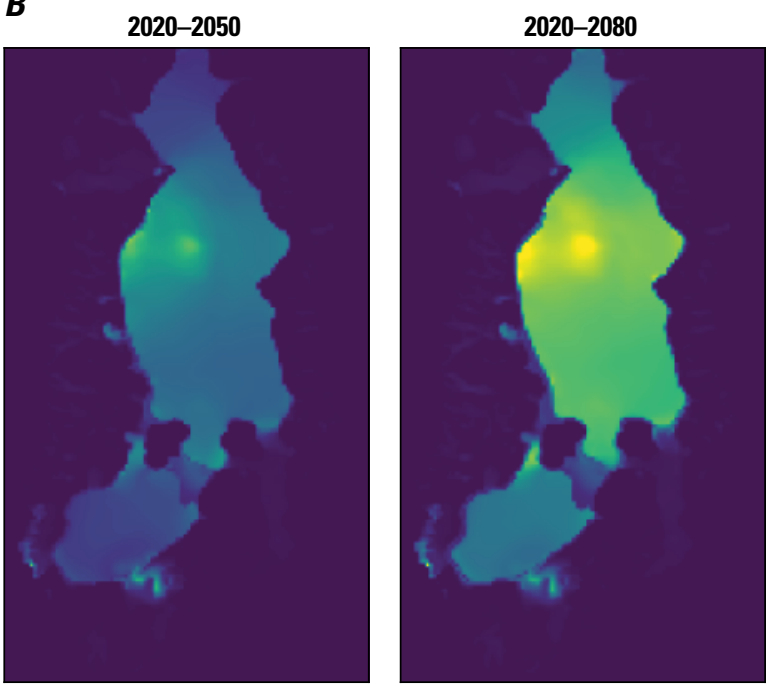

EXPLANATION

Standard deviation of simulated drawdown from 2020 levels, in feet

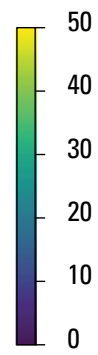

C
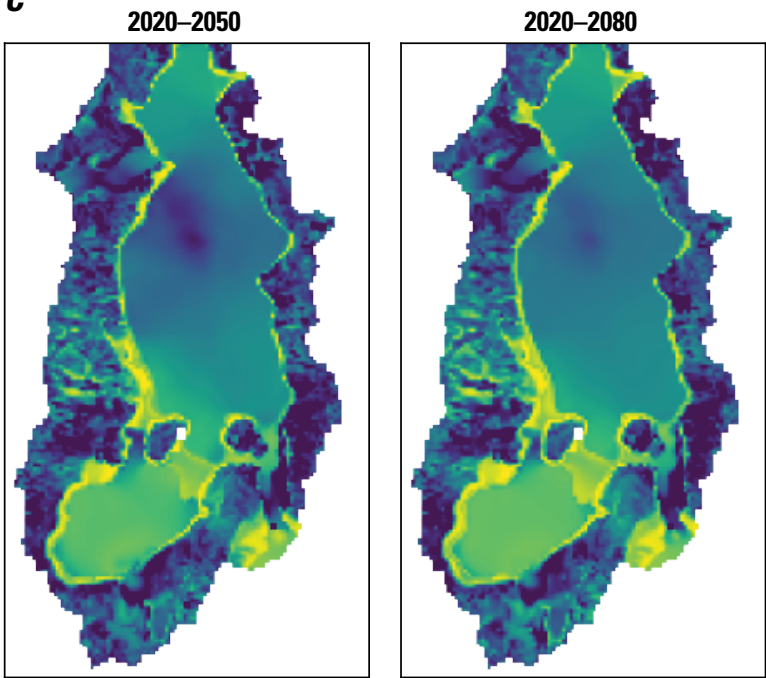

EXPLANATION

Uncertainty reduction of drawdown forecasts, in percent

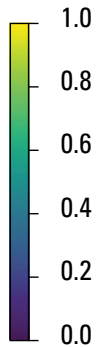




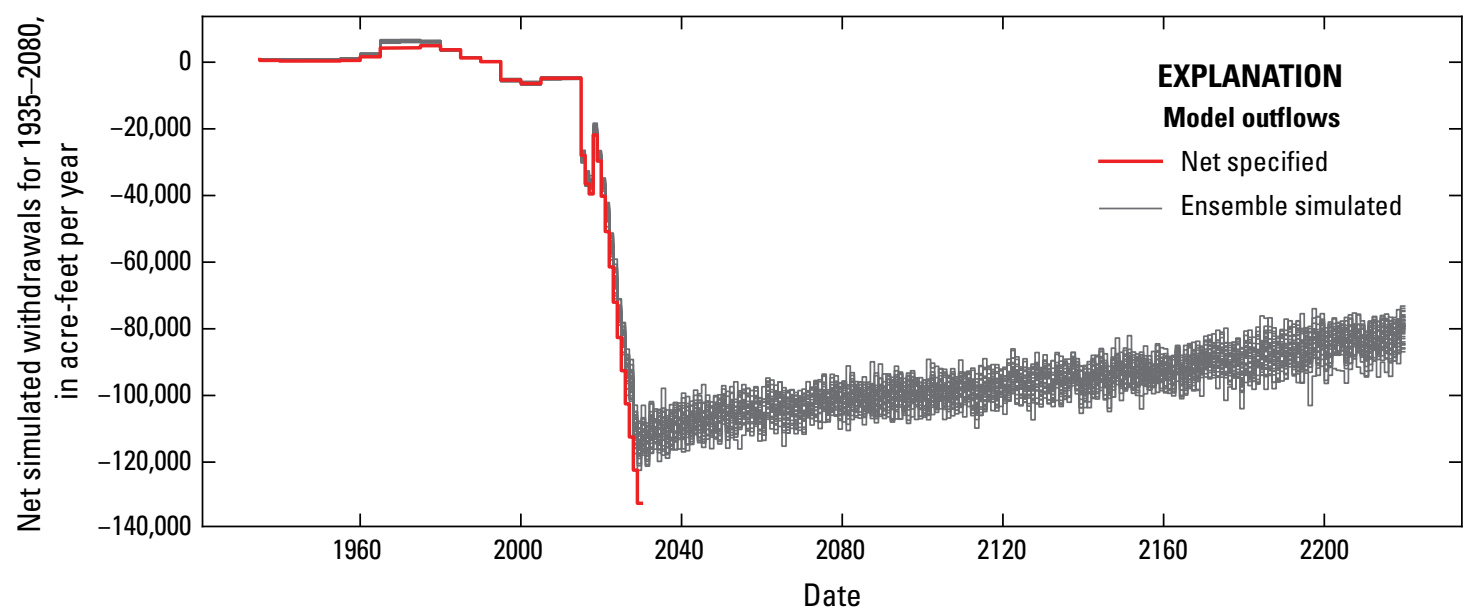

Figure 24. Graph showing net specified (red) and ensemble simulated (black) model outflows through the MODFLOW WEL package. Net outflows are calculated as summed WEL package inflows (incidental recharge, enhanced recharge, underflow into model) minus summed WEL package outflows (all sources of pumping). Deviation from net specified outflows is due to reduced simulated pumping in desaturated model cells.

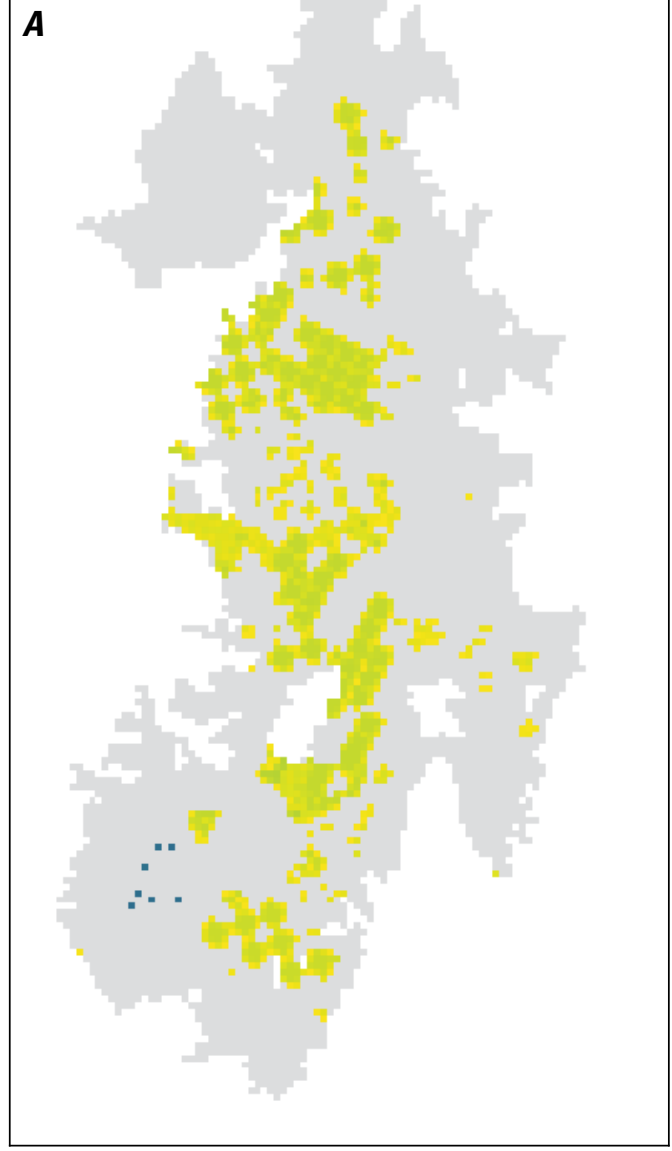

EXPLANATION

Specified pumping, in acre-feet per year

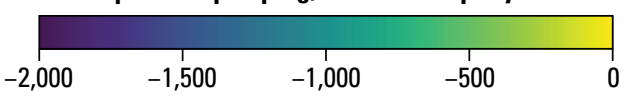

Basin-fill material within the model

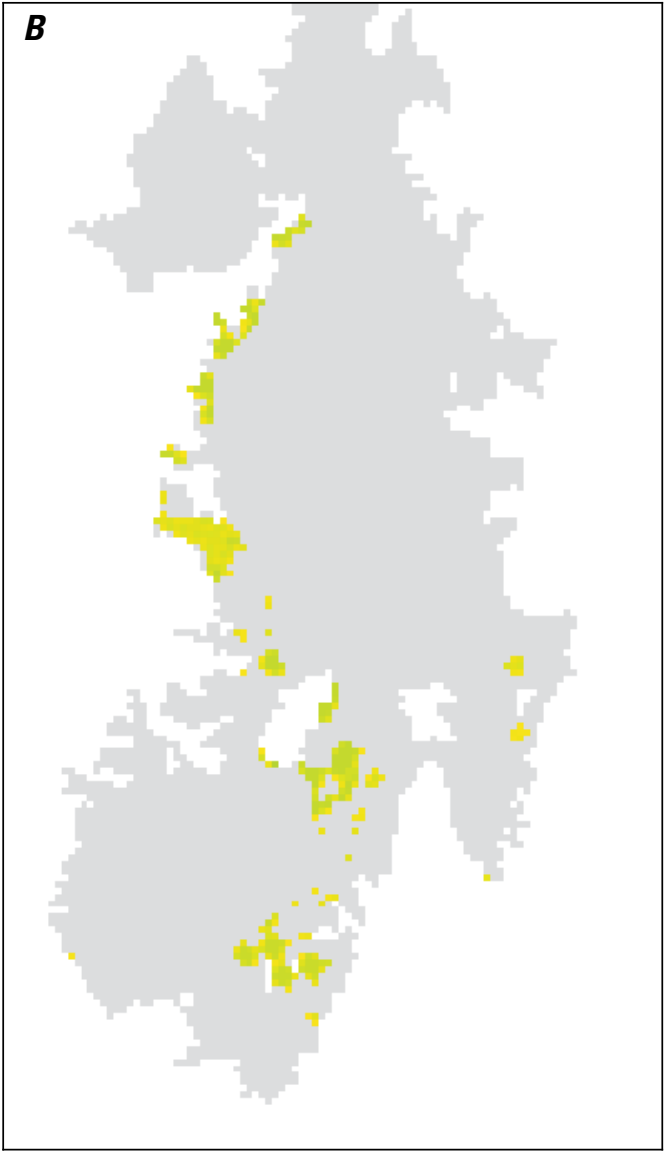

EXPLANATION

Rejected pumping, in acre-feet per year

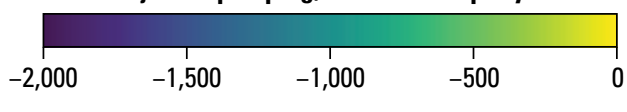

Basin-fill material within the model

Figure 25. Map views of model area showing specified MODFLOW WEL package fluxes simulated in year $2079(A)$ and amount of specified fluxes not simulated owing to desaturation of model cells in year $2079(B)$, in acre-feet per year. 
Simulated drawdown at site 9 is representative of forecasted conditions in the vicinity of municipal supply wells in the Kingman subbasin (fig. 26). The future withdrawal scenario simulates a mean groundwater-level decline of $89.2 \mathrm{ft}$ (standard deviation $9.4 \mathrm{ft}$ ) from 2020 to 2050 and $206.1 \mathrm{ft}$ (standard deviation $19.6 \mathrm{ft}$ ) from year 2020 to 2080 . Site 7 is likewise representative of forecasted conditions in the northern extent of the Kingman subbasin near current and potential future agricultural development (fig. 27). The future withdrawal scenario simulates a mean groundwater-level decline of $128.1 \mathrm{ft}$ (standard deviation $11.9 \mathrm{ft}$ ) from year 2020 to 2050 and $241.0 \mathrm{ft}$ (standard deviation $21.1 \mathrm{ft}$ ) from 2020 to 2080 .

Simulated drawdown at site 2 is representative of forecasted conditions in the southern part of the Hualapai subbasin near current and potential future agricultural development (fig. 28). The future withdrawal scenario simulates a mean groundwaterlevel decline of $130.4 \mathrm{ft}$ (standard deviation $17.4 \mathrm{ft}$ ) from year 2020 to 2050 and $271.9 \mathrm{ft}$ (standard deviation $37.1 \mathrm{ft}$ ) from year 2020 to 2080 .
Forecasted hydraulic heads at observation sites in the Kingman subbasin are slightly to moderately higher as simulated by the future withdrawal scenario that includes enhanced recharge (figs. 26, 27 and appendix 1). The largest differences are simulated at sites 4, 8, 9, 10, and 11 where mean simulated hydraulic heads in the enhanced recharge scenario are 18-23 ft higher in year 2050 and 36-43 ft higher in 2080 compared to simulated hydraulic heads in the future withdrawal scenario. No difference is observed between groundwater levels simulated by the two scenarios at observation sites in the Hualapai subbasin (fig. 27 and appendix 1).

Mean depth to water in the Kingman subbasin simulated in the future withdrawal scenario exceeds $1,200 \mathrm{ft}$ between years 2155 and 2214 (median year 2171; fig. 29). In the future withdrawal plus enhanced recharge scenario (fig. 19 and table 5), mean depth to water in the subbasin exceeds $1,200 \mathrm{ft}$ between years 2163 and 2207 (median year 2180), except for one model realization in which the subbasin does not reach an mean depth to water of $1,200 \mathrm{ft}$ by the end of forecast simulation (year 2220).

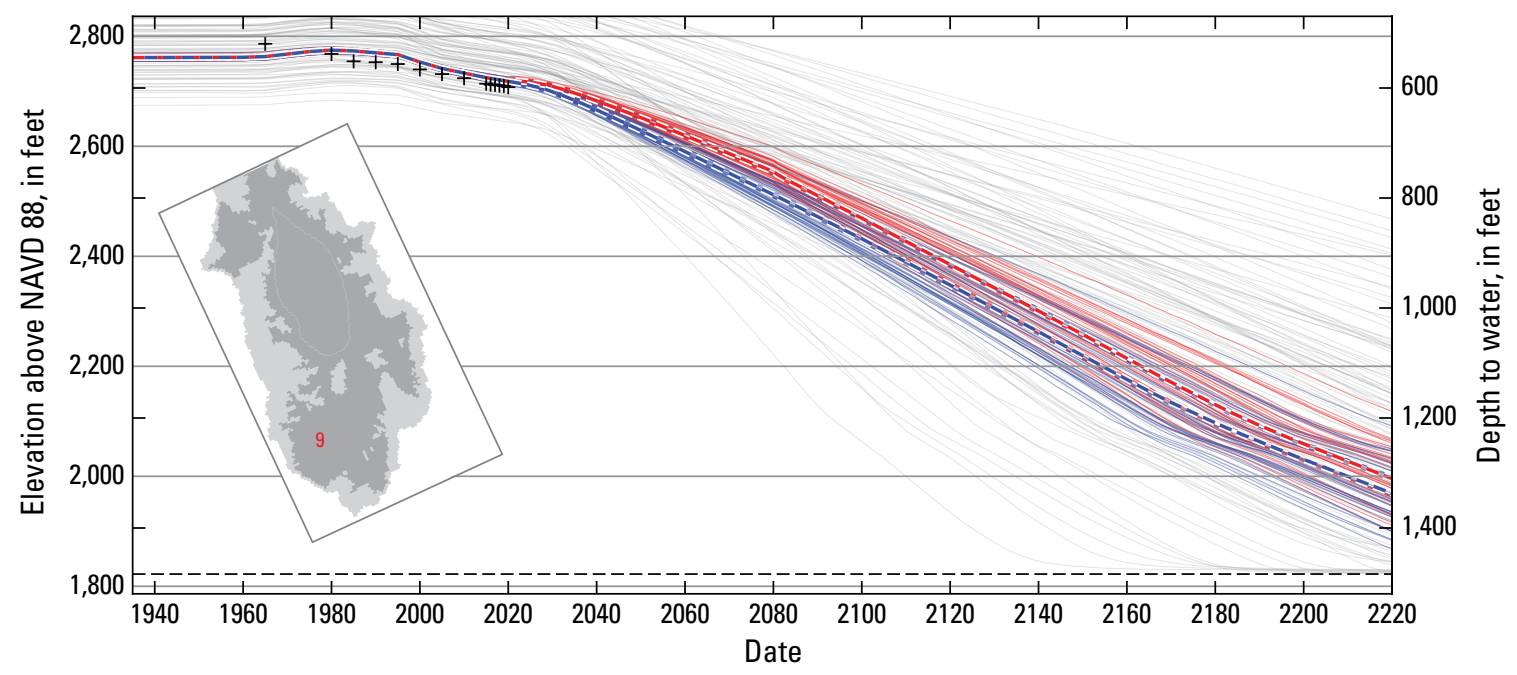

EXPLANATION

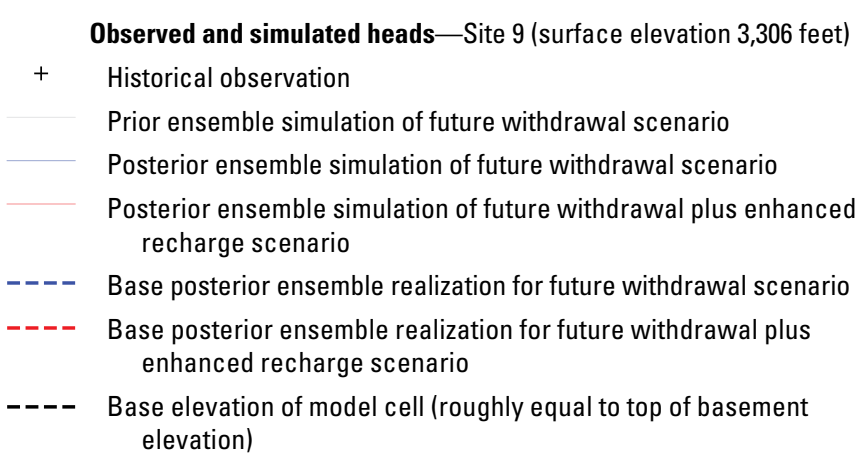

Figure 26. Graph showing simulated hydraulic heads at site 9 . 
Figure 27. Graph showing simulated hydraulic heads at site 7 .
Figure 28. Graph showing simulated hydraulic heads at site 2.

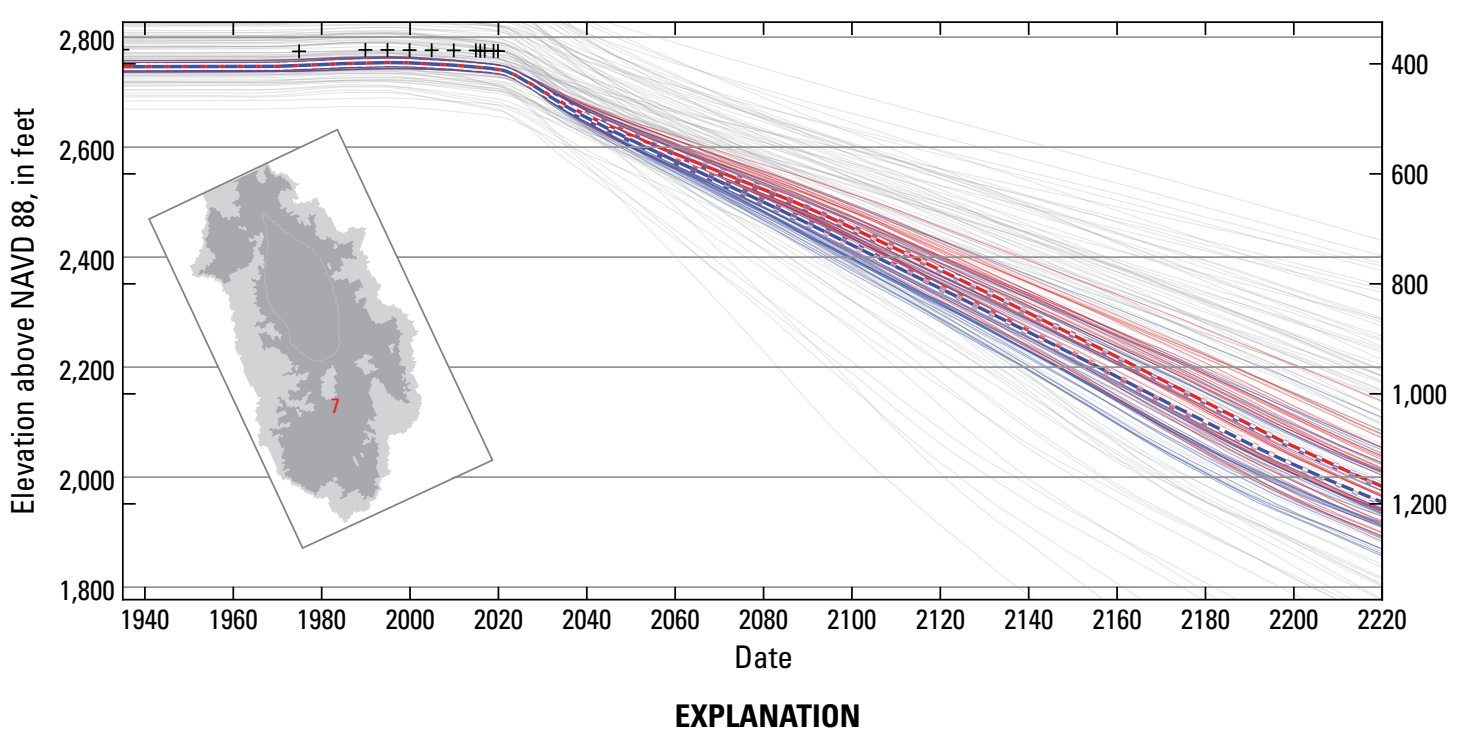

Observed and simulated hydraulic heads - Site 7 (surface elevation 3,152 feet)

$+\quad$ Historical observation

Prior ensemble simulation of future withdrawal scenario

Posterior ensemble simulation of future withdrawal scenario

Posterior ensemble simulation of future withdrawal plus enhanced recharge scenario

--- - Base posterior ensemble realization for future withdrawal scenario

--- $\quad$ Base posterior ensemble realization for future withdrawal plus enhanced recharge scenario

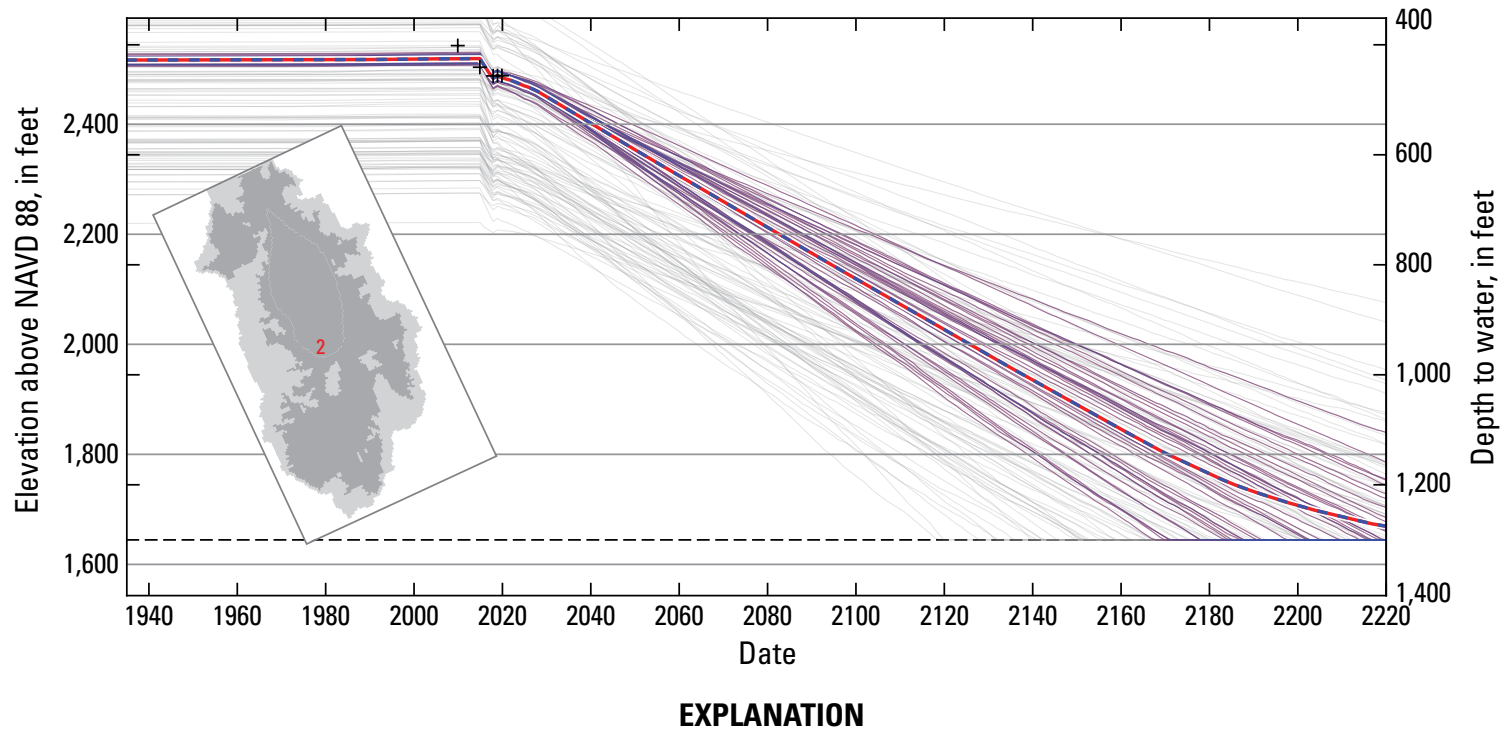

Observed and simulated hydraulic heads - Site 2 (surface elevation 2,945 feet)

$+\quad$ Historical observation

Prior ensemble simulation of future withdrawal scenario

Posterior ensemble simulation of future withdrawal scenario

Posterior ensemble simulation of future withdrawal plus enhanced recharge scenario

---- Base posterior ensemble realization for future withdrawal scenario

---- Base posterior ensemble realization for future withdrawal plus enhanced recharge scenario

Base elevation of model cell (roughly equal to top of basement elevation) 


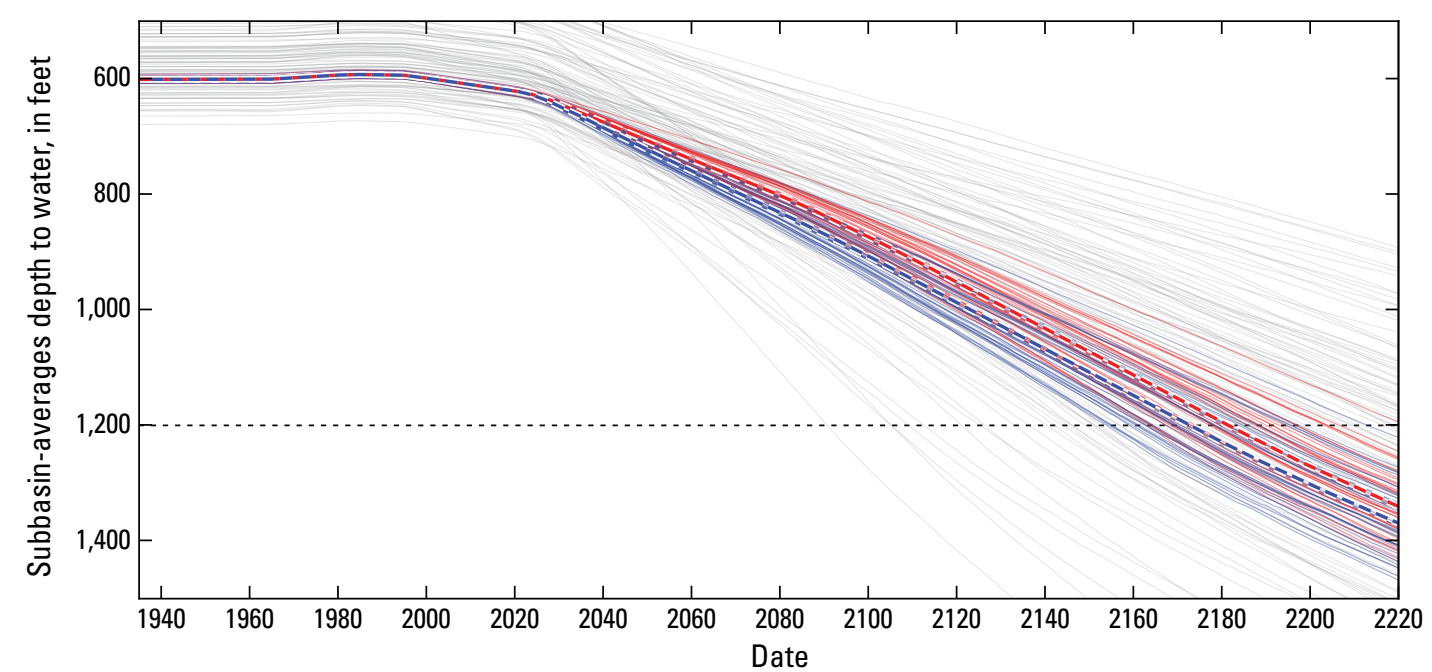

EXPLANATION
Figure 29. Graph showing simulated mean depth to water, in feet, in Kingman subbasin.

\section{Model Limitations and Assumptions}

Hydrologic models are simplified representations of complex environmental systems; thus, these models require the modeler to make certain assumptions and the model to have related limitations. The main assumptions and limitations related to HVHM are briefly considered in this section. Numerous assumptions are necessary to develop a model that adequately simulates past conditions and provides forecasts of future conditions within reasonable ranges of uncertainty. In this regard, the assumptions and simplifications contained in HVHM are deemed acceptable within the context of the model's purpose to forecast groundwater-level declines in the Hualapai Valley basin-fill aquifer associated with large scale increases in groundwater withdrawals, and to do so with and without the additional recharge currently planned at potential enhanced infiltration projects. However, the model should not be repurposed without careful consideration of the importance of these assumptions on any new scenarios.

Simulated groundwater withdrawals for existing agricultural use through the year 2018 are based on analysis by the Arizona Water Science Center Water Use Group (Read and Tadayon, 2021). Their estimates of monthly withdrawals are based on observed crop type and condition, irrigation design, and climatic factors. Simulated withdrawal rates beginning in 2019 come from the net withdrawal of 2.7 acre-feet per acre included in the scenario provided by Mohave County. This rate is applied uniformly over all acreage simulated to become active starting in 2019. More precise forecasts for the near term (less than 10 years) could be achieved by simulating specific crop mixes, irrigation systems, and climate change effects while maintaining a reasonable level of accuracy in the results. Further into the future, however, any precision gained by adding this level of complexity would be overwhelmed by much greater uncertainty in the input values and thus a loss of accuracy in the final outcomes. This uncertainty would come from unanticipated changes in crop types and irrigation methods from that assumed in the model, agricultural expansion that occurs much faster or slower than anticipated, or agricultural contraction, and (or) greater or lesser effects resulting from climate change. The possibility of unexpected changes in human population, commercial water needs, and (or) industrial water needs compounds the uncertainty of forecasts further into the future.

Structural limitations of HVHM include the representation of the basin-fill aquifer and mountain bedrock as distinct zones in a single-layer model grid. Groundwater flow can be simulated horizontally between the mountain bedrock and basin-fill material zones but not vertically. Groundwater flow within bedrock underlying basin-fill alluvium is not simulated. As a result, the Kingman and Hualapai subbasins are simulated to become hydraulically disconnected before 2050 . In reality, some 
level of connection could remain if the bedrock is fractured and sufficiently permeable. However, groundwater-level observations on either side of the bedrock high reveal a hydraulic gradient much steeper than anywhere else within the basin-fill aquifer, indicating low transmissivity.

Another structural limitation of the model relates to dewatering that occurs in cells along the margins of the modeled basin-fill aquifer. Forecasted groundwater declines are based on the simulated locations and levels of future pumping. However, once model cells are dewatered, groundwater withdrawals are no longer simulated in those cells and the specified amount of pumping in the future withdrawal scenario is not fully simulated. This occurs in the model cells representing basin-fill material along the west edge of the Hualapai subbasin and southeast of the Kingman Fault in the Kingman subbasin (fig. 25; see fig. 1 for locations geographic features). In order to satisfy the full volume of expected future withdrawal in the provided scenarios, the scenarios could be adjusted by reducing the amount of simulated pumping at the basin margins and increase pumping toward the center of the basin. This would assume confidence that the margins of the basin-fill aquifer are actually going to desaturate, and that users would continue to irrigate these areas by piping water from wells drilled into the deeper parts of the basin.

Although simulated natural inflows (for example, natural recharge and Truxton Wash) and outflows (for example, underflow toward Lake Mead) are rough approximations with substantial uncertainties, they are nonetheless in line with previous estimates and are very small in magnitude compared to future simulated withdrawals. For the long-term forecasts presented in this report, sensitivities to these boundary conditions are considered minor.

An obvious limitation of any forward-looking model is that the further out the model forecasts, the greater the uncertainty. Therefore, in the HVHM scenarios the forecasted groundwaterlevel declines between 2020 and 2080 are much more uncertain than forecasted declines between 2020 and 2050. The forecast of when mean depth to water exceeds 1,200 ft in the Kingman subbasin is highly uncertain because it is simulated to occur more than 100 years into the future.

The two existing infiltration projects and nine potential future projects are simulated under the assumption that they will operate at their full infiltration capacity as estimated by Mohave County. This represents a best-case scenario for simulated mitigation of groundwater-level declines.

\section{Summary and Conclusions}

A numerical groundwater flow model of the Hualapai Valley Basin in northwestern Arizona was developed to assist water-resource managers in understanding the potential effects of projected groundwater withdrawals on groundwater levels in the basin. The Hualapai Valley Hydrologic Model (HVHM) simulates the hydrologic system for the years 1935 through 2219 , including future withdrawal scenarios that simulate large-scale agricultural expansion with and without enhanced groundwater recharge from potential new infiltration basin projects. HVHM is a highly parameterized model $(75,586$ adjustable parameters) capable of simulating grid-scale variability in aquifer properties (for example, conductivity, specific yield, and specific storage) and system stresses (for instance, natural recharge and groundwater withdrawals).

In the future withdrawal scenario provided by Mohave County, the HVHM simulates mean groundwater-level declines at several locations in the Kingman subbasin between 87 and $128 \mathrm{ft}$ by year 2050 and between 204 and 241 by year 2080 . Mean simulated groundwater-level declines in the Hualapai subbasin range from 44 to $210 \mathrm{ft}$ by year 2050 and from 107 to $350 \mathrm{ft}$ by year 2080 . Mean simulated depth to water in the Kingman subbasin exceeds $1,200 \mathrm{ft}$ between the years 2155 and 2214 (median year of exceedance 2171).

In the "future withdrawal plus enhanced recharge" scenario provided by Mohave County, groundwater-level declines simulated in the Kingman subbasin are are lessened by 8 to $23 \mathrm{ft}$ to between 66 and $120 \mathrm{ft}$ by year 2050 and lessened by 23 to $43 \mathrm{ft}$ to between 161 and $218 \mathrm{ft}$ by year 2080. Mean depth to water in the subbasin exceeds $1,200 \mathrm{ft}$ between the years 2163 and 2207 (median year of exceedance 2180), except for one model realization in which Kingman subbasin does not reach a mean depth to water of $1,200 \mathrm{ft}$ by the end of forecast simulation (year 2220). Simulated drawdowns in the Hualapai subbasin are unaffected by simulated enhanced recharge in the Kingman subbasin.

In both forecast scenarios, Kingman and Hualapai subbasins become hydraulically disconnected by the year 2050 after desaturation of the basin-fill aquifer above a shallow bedrock high east of Long Mountain. Desaturation also occurs in model cells along the margins of the basin-fill aquifer, leading to reduction of total future pumping below specified inputs by about 7 percent in 2029 and 12 percent in 2079.

Forecasted groundwater-level declines in each scenario are presented as the mean and standard deviation of results obtained from an ensemble of 40 models. These 40 model realizations contain parameter values drawn from distributions estimated via history matching with an iterative ensemble smoother. Taken as a group, ensemble forecast results include an appropriate level of uncertainty based on available observation data and prior knowledge of aquifer properties. The results of any single model realization outside the context of the ensemble should be interpreted with caution.

The largest source of uncertainty in forecasted groundwater conditions is caused by the unknown rates and locations of future pumping. The range of forecasted groundwater-level declines simulated by the posterior model ensemble are otherwise considered conservative with regards to uncertainty but are only relevant in the context of simulated pumping locations and rates. Substantial changes in assumed scenario factors, particularly timing, location, and magnitude of withdrawal rates, would warrant development and analysis of revised scenarios. 


\section{References Cited}

Adams, D., and Comrie, A.C., 1999, The North American Monsoon: Bulletin of the American Meteorological Society, v. 78, p. 2197-2213.

Anderson, T.W., and Freethy, G.W., 1995, Simulation of ground-water flow in alluvial basins in south-central Arizona and parts of adjacent States: U.S. Geological Survey Professional Paper 1406-D.

Anning, D.L., Truini, M., Flynn, M.E., and Remick, W.H., 2007, Groundwater occurrence and movement, 2006, and water-level changes in the Detrital, Hualapai, and Sacramento Valley Basins, Mohave County, Arizona: U.S. Geological Survey Scientific Investigation Report 2007-5182, 24 p.

Arizona Department of Water Resources, 2010, Arizona Water Atlas Volume 4 Upper Colorado River Planning Area, Arizona Department of Water Resources web page, accessed July 1, 2019, at https://infoshare.azwater.gov/docushare/ dsweb/Get/Document-10429/Volume_4_final_web.pdf.

Arizona Department of Water Resources, 2020, Groundwater site inventory (GWSI) database: Arizona Department of Water Resources database, accessed March 26, 2020, at https://gisweb2.azwater.gov/gwsi.

Bakker, M., Post, V., Langevin, C.D., Hughes, J.D., White, J.T., Starn, J.J., 2016, Scripting MODFLOW model development using Python and FloPy: Groundwater, v. 54, no. 5, p. 733739. [Also available at https://doi.org/10.1111/gwat.12413.]

Beard, L.S., Kennedy, J., Truini, M., and Felger, T., 2011, Geologic map of Detrital, Hualapai, and Sacramento Valleys and surrounding areas, northwest Arizona: U.S. Geological Survey Open-File Report 2011-1225, 43 p., 1 sheet, scale 1:250,000. [Also available at http://pubs.usgs.gov/ of/2011/1225/.]

Bevin, K., and Binley, A., 1992, The future of distributed models; model calibration and uncertainty prediction: Hydrological Processes, v. 6, p. 279-298. [Also available at https://doi.org/10.1002/hyp.3360060305.]

Bureau of Reclamation, 2020, Lake Mead annual high and low elevations (1935-2020): Bureau of Reclamation website, accessed June 8, 2020, at https://www.usbr.gov/lc/region/ g4000/lakemead_line.pdf.

Buschatzke, T., 2016, Hualapai Valley Groundwater Basin, Letter to Mohave County Board of Supervisors, Phoenix, Arizona: Arizona Department of Water Resources, 10 p., accessed June 8, 2020, at, https://new.azwater.gov/sites/ default/files/ADWRresponsetoMohaveCountyINArequest. pdf.
Chen, Y., and Oliver, D.S., 2013, Levenberg-Marquardt forms of the iterative ensemble smoother for efficient history matching and uncertainty quantification: Computational Geosciences, v. 17, p. 689-703. [Also available at https://doi.org/10.1007/ s10596-013-9351-5.]

Cunningham, W.L., and Schalk, C.W., comps., 2011, Groundwater technical procedures of the U.S. Geological Survey: U.S. Geological Survey Techniques and Methods 1-A1, 151 p. [Also available at https://doi.org/10.3133/tm1A1.]

Doherty, J., and Welter, D., 2010, A short exploration of structural noise, Water Resources Research, v. 46, no. 5, 14 p. [Also available at https://doi.org/10.1029/2009WR008377.]

Evans, M., and Moshonov, H., 2006, Checking for prior-data conflict: Bayesian Analysis, v.1, no. 4, p. 893-914. [Also available at https://doi.org/10.1214/06-BA129.]

Faulds, J.E., Schreiber, B.C., Langenheim, V.E., Hinz, N.H., Shaw, T.H., Heizler, M.T., Perkins, M.E., El Tabakh, M., and Kunk, M.J., 2016, Paleogeographic implications of late Miocene lacustrine and nonmarine evaporite deposits in the Lake Mead region-Immediate precursors to the Colorado River: Geosphere, v. 12, no. 3, p. 721-767. [Also available at https://doi.org/10.1130/GES01143.1.]

Fenneman, N.M., 1931, Physiography of western United States (1st ed.): New York, McGraw-Hill, 534 p.

Fienen, M.N., D’Oria, M., Doherty, J.E., and Hunt, R.J., 2013, Approaches in highly parameterized inversion; bgaPEST, a Bayesian geostatistical approach implementation with PESTDocumentation and instructions: U.S. Geological Survey Techniques and Methods, book 7, section C9, 86 p. [Also available at https://doi.org/10.3133/tm7C9.]

Flint, A.L., and Flint, L.E., 2007a, Application of the basin characterization model to estimate in-place recharge and runoff potential in the Basin and Range carbonate-rock aquifer system, White Pine County, Nevada, and adjacent areas in Nevada and Utah: U.S. Geological Survey Scientific Investigations Report 2007-5099, 20 p. [Also available at https://doi.org/10.3133/ sir20075099.]

Flint, L.E., and Flint, A.L., 2007b, Regional analysis of groundwater recharge, in Stonestrom, D.A., Constantz, J., Ferre, T.P.A., and Leake, S.A., eds., Ground-water recharge in the arid and semiarid southwestern United States: U.S. Geological Survey Professional Paper 1703, p. 29-60. [Also available at https://doi.org/10.3133/pp1703B.]

Freethey, G.W., and Anderson, T.W., 1986, Predevelopment hydrologic conditions in the alluvial basins of Arizona and adjacent parts of California and New Mexico: U.S. Geological Survey, Hydrologic Investigations Atlas HA-664, sheet 1 of 3. [Also available at https://doi.org/10.3133/ha664.] 
Garner, B.D., and Truini, M., 2011, Groundwater budgets for Detrital, Hualapai, and Sacramento Valleys, Mohave County, Arizona, 2007-2008: U.S. Geological Survey Scientific Investigation Report 2011-5159, 34 p. [Also available at https:// doi.org/10.3133/sir20115159.]

Gillespie, J.B., Bently, C.B., and Kam, W., 1966, Basic hydrologic data of the Hualapai, Sacramento, and Big Sandy Valleys, Mohave County, Arizona: Arizona State Land Department, Water-Resources Report 26, 39 p.

Gillespie, J.B., and Bently, C.B., 1971, Geohydrology of Hualapai and Sacramento Valleys, Mohave County, Arizona: U.S. Geological Survey Water-Supply Paper 1899-H, 2 pls., scale $1: 125,000,37 \mathrm{p}$.

Healy, R.W., Winter, T.C., LaBaugh, J.W., and Franke, O.L., 2007, Water budgets - Foundations for effective water-resources and environmental management: U.S. Geological Survey Circular 1308, 90 p. [Also available at https://doi.org/10.3133/cir1308.]

Ivanich, P.A., and Conway, B.D., 2009, Preliminary estimate of groundwater in storage for the Hualapai Valley groundwater basin, Mohave County, Arizona: Arizona Department of Water Resources Open-File Report Number 11, 31 p.

Kennedy, J.R., 2018, Changes in Earth's gravity reveal changes in groundwater storage: U.S. Geological Survey Fact Sheet 2018-3032, 4 p. [Also available at https://doi. org/10.3133/fs20183032.]

Kennedy, J.R., and Bucci, L.B., 2021, Repeat microgravity data from Hualapai Basin, 2008-2019, Mohave County, Arizona: U.S. Geological Survey data release, https://doi.org/10.5066/ P9MJRMSQ.

Kennedy, J.R., Pool, D.R., and Carruth, R.L., 2021, Procedures for field data collection, processing, quality assurance and quality control, and archiving of relative- and absolute-gravity surveys: U.S. Geological Survey Techniques and Methods, book 2, chap. D4, 50 p., https://doi.org/10.3133/tm2D4.

Knight, J.E., 2021, Data release for transient groundwater model of the Hualapai Valley Groundwater Basin, Mohave County, Arizona: U.S. Geological Survey data release, https://doi.org/10.5066/P9017DI9.

Laney, R.L., 1977, Geohydrologic reconnaissance of Lake Mead National Recreation Area-Temple Bar to Grand Wash Cliffs, Arizona (revised in 1979): U.S. Geological Survey Open- File Report 79-688, 1 pl., scale 1:62,500., 72 p.

Langenheim, V.E., Beard, L.S., and Faulds, J.E., 2010, Implications of geophysical analysis on basin geometry and fault offsets in the northern Colorado River extensional corridor and adjoining Lake Mead region, Nevada and Arizona, in Umhoefer, P.J., Beard, L.S., and Lamb, M.A., eds., Miocene tectonics of the Lake Mead region, central Basin and Range: Geological Society of America Special Paper, 21 p.
Matrix New World Engineering, 2019, Northwest basins groundwater resource assessment, Mohave County, Arizona: Matrix project no. 18-1012, prepared for Arizona Department of Water Resources, $94 \mathrm{p}$.

McKenna, S.A., Akhriev, A., Ciaurri, D.E., and Zhuk, S., 2020, Efficient uncertainty quantification of reservoir properties for parameter estimation and production forecasting: Mathematical Geoscience, v. 52, p. 233-251. [Also available at https://doi. org/10.1007/s11004-019-09810-y.]

Moore, C., and Doherty, J., 2005, Role of the calibration process in reducing model predictive error, Water Resources Research, $\mathrm{v}$. 41, no. 5,14 p.

Natural Resources Conservation Service, Soil Survey Staff, 2020, SSURGO database - Web soil survey: U.S. Department of Agriculture database, accessed July 17, 2020, at https:// websoilsurvey.nrcs.usda.gov/.

Nishikawa, T., Izbicki, J.A., Hevesi, J.A., Stamos, C.L., and Martin, P., 2004, Evaluation of geohydrologic framework, recharge estimates and ground-water flow of the Joshua Tree area, San Bernardino County, California: U.S. Geological Survey Scientific Investigations Report 2004-5267, 115 p. [Also available at https://doi.org/10.3133/sir20045267.]

Niswonger, R.G., Panday, S., and Ibaraki, M., 2011, MODFLOWNWT; A Newton formulation for MODFLOW-2005: U.S. Geological Survey Techniques and Methods 6-A37, 44 p.

Oliver, D.S., 2020, Diagnosing reservoir model deficiency for model improvement: Journal of Petroleum Science and Engineering, v. 193, 10 p. [Also available at https://doi. org/10.1016/j.petrol.2020.107367.]

Pool, D.R., and Eychaner, J.H., 1995, Measurements of aquiferstorage change and specific yield using gravity surveys: Ground Water, v. 33, no. 3, p. 425-432

PRISM Climate Group, 2020, Recent years (Jan. 1981-Nov. 2019): Oregon State University website, accessed June 17, 2020, at https://prism.oregonstate.edu/recent/.

Read, A.L., and Tadayon, S., 2021, Estimated crop irrigation water use withdrawals in Hualapai Valley Groundwater Basin, Arizona for 2014-2018: U.S. Geological Survey data release, https://doi.org/10.5066/P92C2JXD.

Remick, W.H., 1981, Map showing groundwater conditions in the Hualapai Basin Area, Mohave County, Arizona — 1980: State of Arizona Department of Water Resources, Hydrologic Map Series Report Number 4, 1 sheet, scale 1:125,000.

Tadayon, S., 2005, Water withdrawals for irrigation, municipal, mining, thermoelectric power, and drainage uses in Arizona, outside of active management areas, 1991-2000: U.S. Geological Survey Scientific Investigations Report 2004-5293, 28 p. [Also available at https://doi.org/10.3133/sir20045293.] 
Tillman, F.D, Callegary, J.C., Nagler, P.L., and Glenn, E.P., 2012, A simple method for estimating basin-scale groundwater discharge by vegetation in the basin and range province of Arizona using remote sensing information and geographic information systems: Journal of Arid Environments v. 82, p. 44-52.

Tillman, F.D., Cordova, J.T., Leake, S.A., Thomas, B.E., and Callegary, J.B., 2011, Water availability and use pilot program-Methods development for a regional assessment of groundwater availability, southwest alluvial basins, Arizona: U.S. Geological Survey Scientific Investigations Report 2011-5071, 118 p. [Also available at https://pubs.usgs.gov/ sir/2011/5071/.]

Tillman, F.D, Garner, B.D., and Truini, M., 2013, Preliminary groundwater flow model of the basin-fill aquifers in Detrital, Hualapai, and Sacramento Valleys, Mohave County, northwestern Arizona: U.S. Geological Survey Scientific Investigations Report 2013-5122, 52 p., Accessed October 13, 2016, at https://doi.org/10.3133/sir20115071.

Tillman, F.D., Pool, D.R., and Leake, S.A. 2014, The effect of modeled recharge distribution on simulated groundwater availability and capture, Groundwater, v. 53, no. 3, p. 378-388. [Also available at https://doi.org/10.1111/gwat.12210.]

Truini, M., Beard, L.S., and Kennedy, J., 2013, Hydrogeologic framework and estimates of groundwater storage for the Hualapai Valley, Detrital Valley, and Sacramento Valley Basins, Mohave County, Arizona: U.S. Geological Survey Scientific Investigations Report 2012-5275, 47 p. [Also available at https://doi.org/10.3133/sir20125275.]

United States Census Bureau, 2019a, 2019 population estimates [Kingman, Arizona]: U.S. Department of Commerce web interface, accessed July 3, 2019, at https://www.census.gov/ search-results.html?q=population + kingman + arizona\&page $=1 \&$ stateGeo $=$ none\&searchtype $=$ web \&cssp $=$ SERP.

United States Census Bureau, 2019b, 2019 quick facts [Mohave County, Arizona]: U.S. Department of Commerce web interface, accessed July 3, 2019, at https://www.census.gov/ quickfacts/fact/table/mohavecountyarizona/PST045218.
University of Arizona, 2020, The Arizona Meteorological Network: University of Arizona website, accessed July 20, 2020, at https://cals.arizona.edu/AZMET/index.html.

U.S. Geological Survey, 2020a, National Hydrography Dataset [USGS National Hydrography Dataset Best Resolution (NHD) for Hydrologic Unit (HU) 8 - 15010007]: U.S. Geological database, accessed May 5, 2020, at https://www.usgs.gov/corescience-systems/ngp/national-hydrography/access-nationalhydrography-products.

U.S. Geological Survey, 2020b, USGS water data for the Nation: U.S. Geological Survey National Water Information System, accessed March 26, 2020, at https://doi.org/10.5066/F7P55KJN.

Welter, D.E., White, J.T., Hunt, R.J., and Doherty, J.E., 2015, Approaches in highly parameterized inversion-PEST++ Version 3, a Parameter ESTimation and uncertainty analysis software suite optimized for large environmental models: U.S. Geological Survey Techniques and Methods, book 7, chap. C12, 54 p., https://doi.org/10.3133/tm7C12.

Westenbroek, S.M., Kelson, V.A., Dripps, W.R., Hunt, R.J., and Bradbury, K.R., 2010, SWB - A modified Thornthwaite-Mather Soil-Water-Balance code for estimating groundwater recharge: U.S. Geological Survey Techniques and Methods 6-A31, $60 \mathrm{p}$. [Also available at https://doi.org/10.3133/tm6A31.]

White, J. T., 2018, A model independent iterative ensemble smoother for efficient history-matching and uncertainty quantification in very high dimensions. Environmental Modeling \& Software, v. 109, 191-201. [Also available at https://doi.org/10.1016/j.envsoft.2018.06.009.]

White, J. T., Fienen, M. N., and Doherty, J. E., 2016. A python framework for environmental model uncertainty analysis. Environmental Modeling \& Software, v. 85, p. 217-228. [Also available at https://doi.org/10.1016/j.envsoft.2016.08.017.]

White, J.T., Foster, L.K., Fienen, M.N., Knowling, M.J., Hemmings, B. and Winterle, J.R., 2020, Toward reproducible environmental modeling for decision support-A worked example: Frontiers of Earth Science, v. 8, no. 50, 11 p. [Also available at https://doi.org/10.3389/feart.2020.00050.] 
Appendixes 1-3 


\section{Appendix 1. Simulated Groundwater Levels 1935-2080}

Forecasted hydraulic heads for the years 2020 through 2219 are included in the time series plots of the 29 groundwater observation sites (fig. 1.1).

Table 1.1 summarizes the mean and standard deviation of forecasted groundwater levels at each site for the years 2020,2050 , and 2080 as simulated by models drawn from the prior (before automated parameter estimation via history matching, "Mean elevation" and "Standard deviation" [third and fourth columns to the right] under the future withdrawal scenario of table 1.1) and the posterior parameter distributions (after automated parameter estimation, "Mean elevation" and "Standard deviation" [fifth and sixth columns to the right] under the future withdrawal scenario of table 1.1). The percent reduction in uncertainty (eighth column to the right) of forecasted hydraulic heads is measured as a comparison of the prior and posterior standard deviations (fourth and sixth columns to the right). A smaller spread of simulated results from the posterior compared to the prior parameter distribution for a given location and year represents a greater reduction in uncertainty of future conditions gained from the parameter estimation process. Values of the uncertainty reduction metric (eighth column to the right in table 1.1) are calculated as 100 * (1 - [standard deviation of posterior distribution]/ [standard deviation of prior distribution]).

The "Mean elevation" and "Standard deviation" columns (9th and 10th columns to the right, respectively) under the future withdrawal plus enhanced infiltration scenario show the mean and standard deviation of forecasted groundwater levels resulting from the enhanced recharge scenario. Comparing mean elevations simulated by the posterior parameter distribution in each scenario (fifth and ninth columns to the right in table 1.1) shows that forecasted hydraulic heads at observation sites in the Kingman subbasin are slightly to moderately higher as simulated by the enhanced recharge scenario. The largest differences (last column to the right in table 1.1) are simulated at sites $4,8,9,10$, and 11 . No difference is observed between groundwater levels simulated by the two scenarios at observation sites in the Hualapai subbasin.

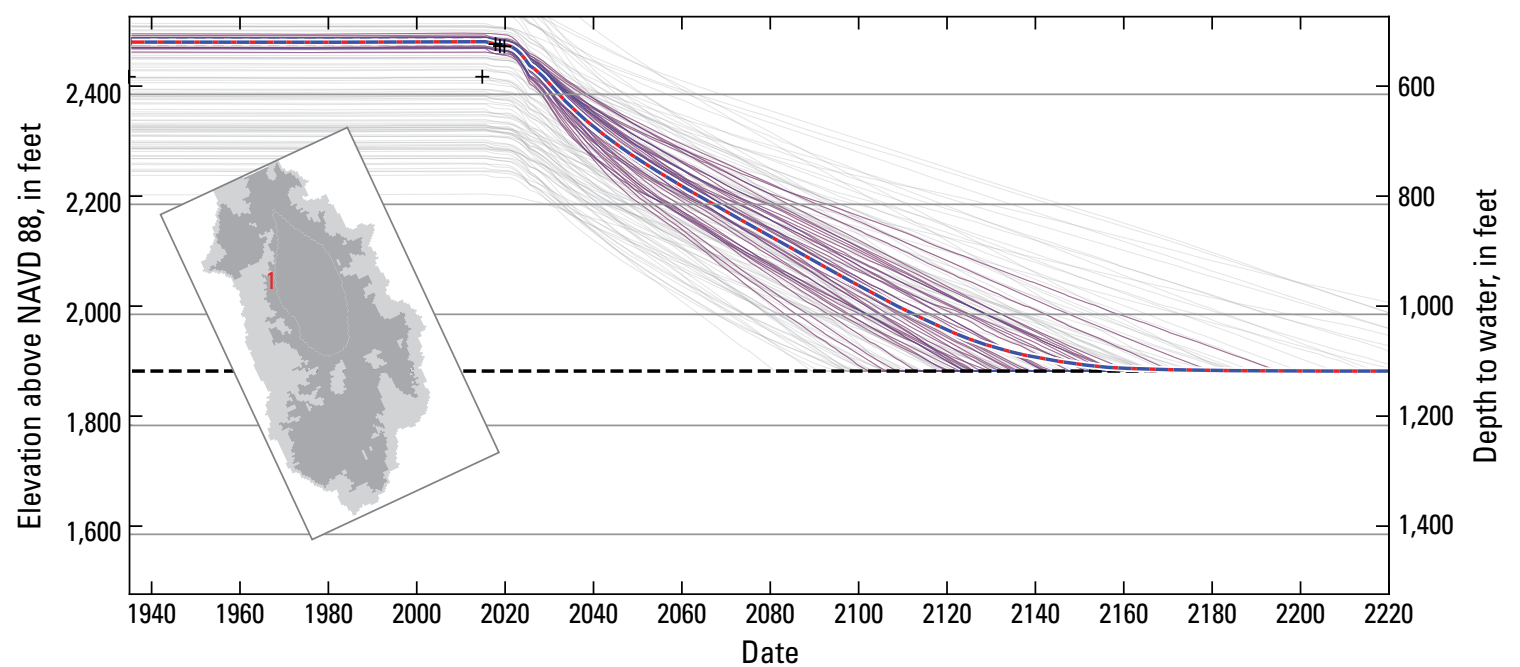

EXPLANATION

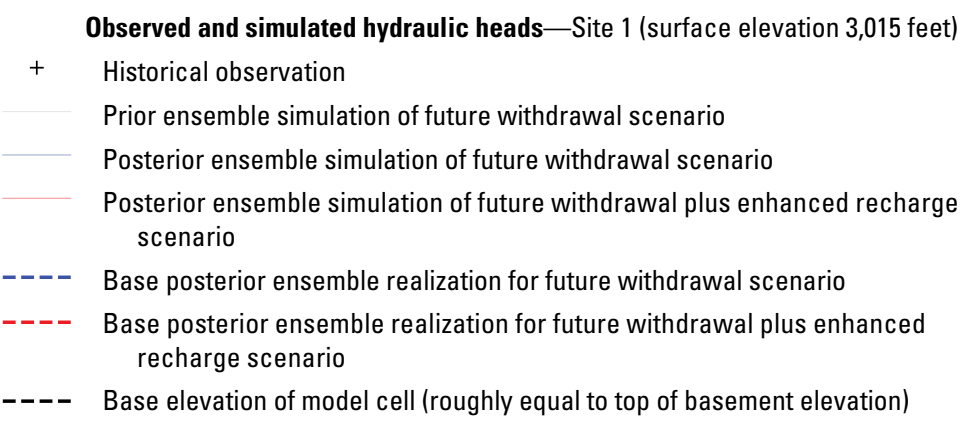

Fig. 1.1. Graphs of observed and simulated groundwater levels at 29 select wells. Locations of the wells are shown in inset maps and figure 20. 


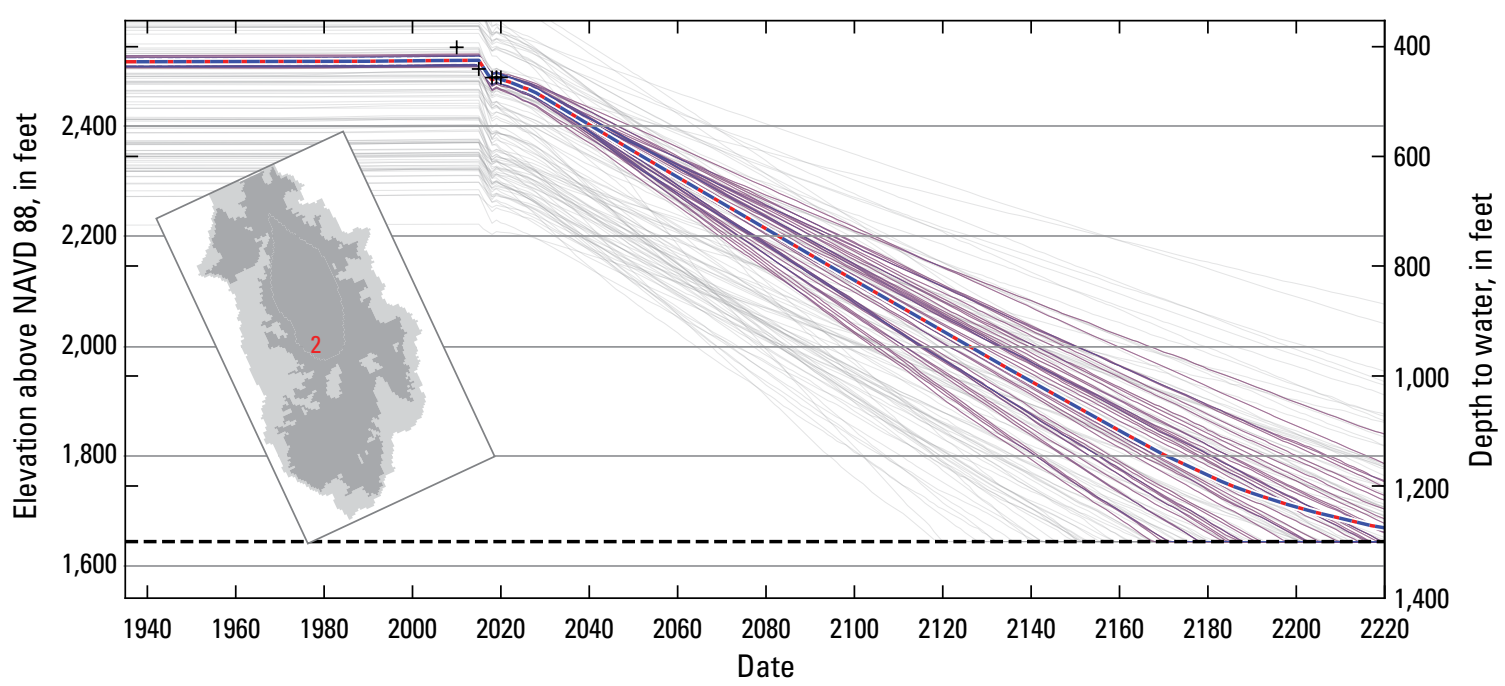

EXPLANATION

Observed and simulated hydraulic heads-Site 2 (surface elevation 2,945 feet)

$+\quad$ Historical observation

Prior ensemble simulation of future withdrawal scenario

Posterior ensemble simulation of future withdrawal scenario

Posterior ensemble simulation of future withdrawal plus enhanced recharge scenario

---- Base posterior ensemble realization for future withdrawal scenario

---- Base posterior ensemble realization for future withdrawal plus enhanced recharge scenario

---- Base elevation of model cell (roughly equal to top of basement elevation)

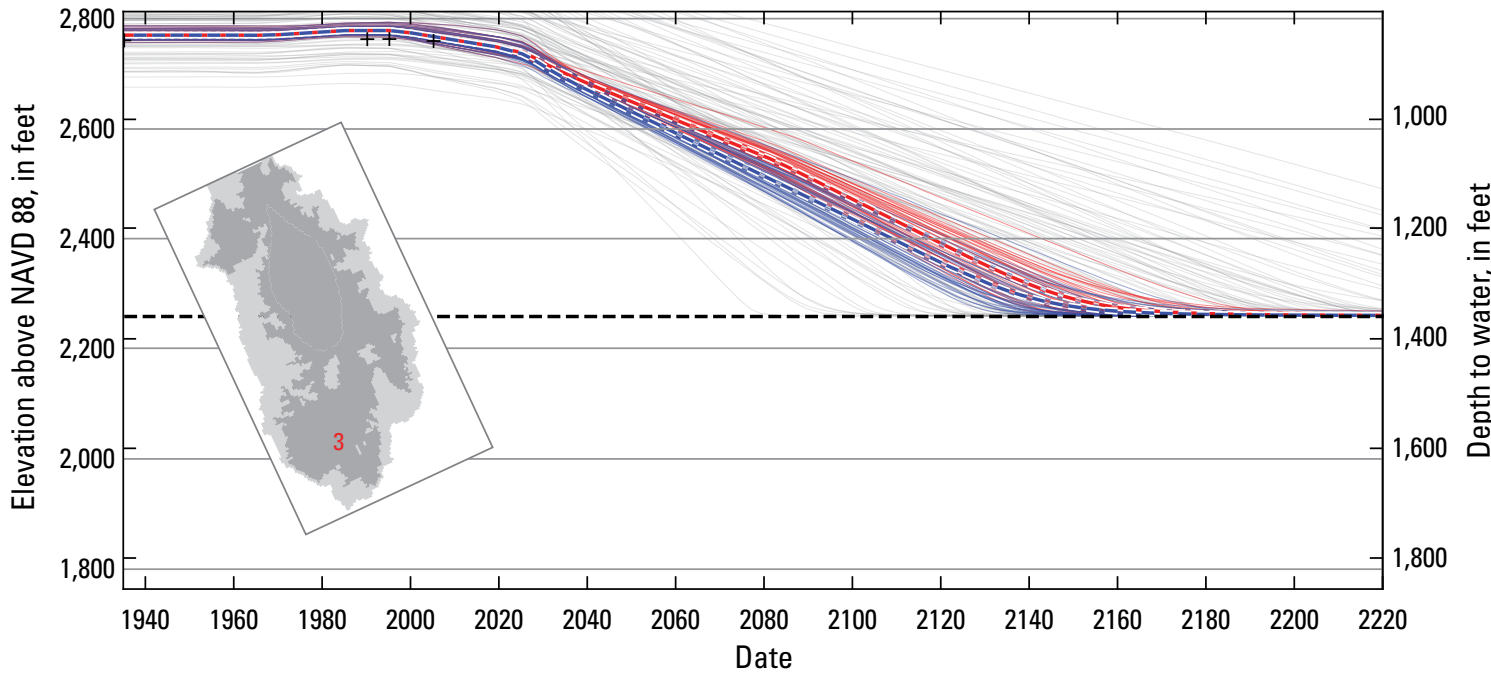

EXPLANATION

Observed and simulated hydraulic heads-Site 3 (surface elevation 3,619 feet)

Historical observation

Prior ensemble simulation of future withdrawal scenario

Posterior ensemble simulation of future withdrawal scenario

Posterior ensemble simulation of future withdrawal plus enhanced recharge scenario

---- Base posterior ensemble realization for future withdrawal scenario

---- Base posterior ensemble realization for future withdrawal plus enhanced recharge scenario

Fig. 1.1.-Continued

Base elevation of model cell (roughly equal to top of basement elevation) 


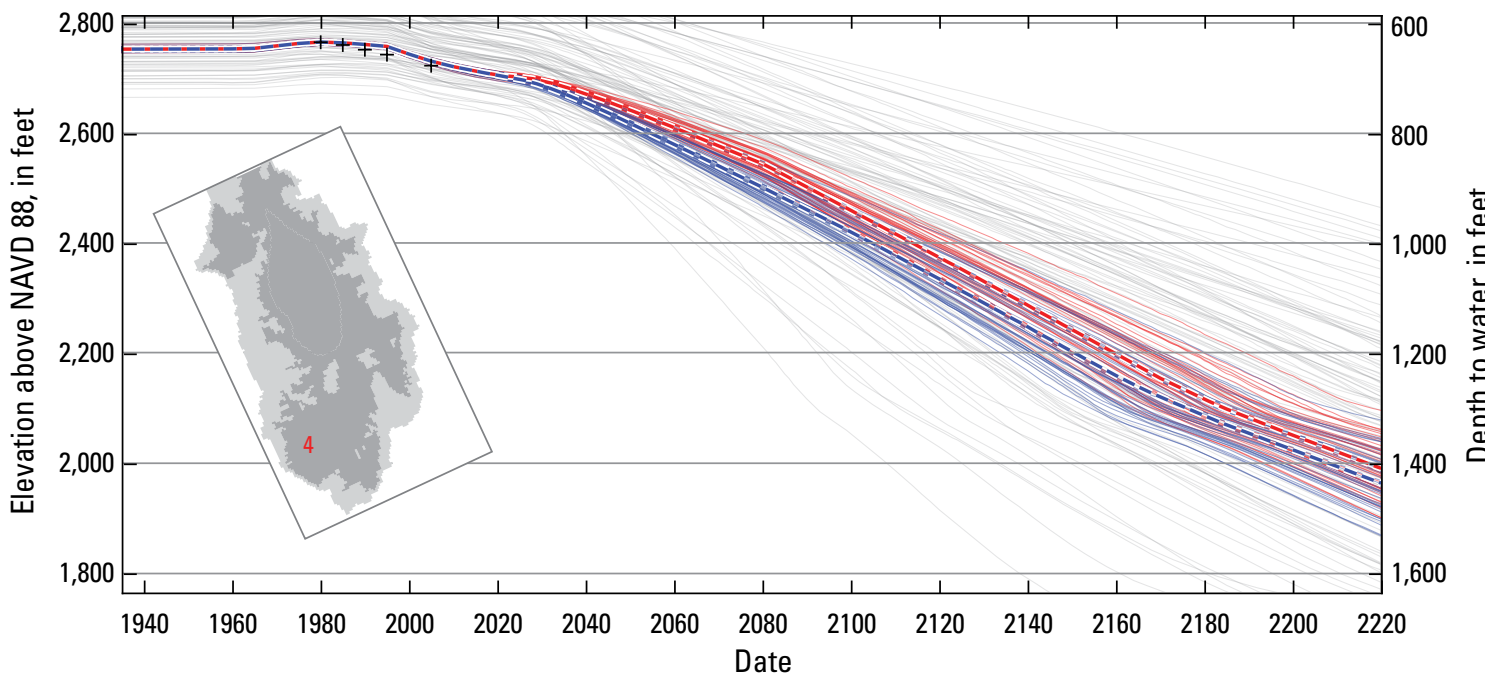

EXPLANATION

Observed and simulated hydraulic heads - Site 4 (surface elevation 3,407 feet)

$+\quad$ Historical observation

Prior ensemble simulation of future withdrawal scenario

Posterior ensemble simulation of future withdrawal scenario

Posterior ensemble simulation of future withdrawal plus enhanced recharge scenario

--- - Base posterior ensemble realization for future withdrawal scenario

---- Base posterior ensemble realization for future withdrawal plus enhanced recharge scenario

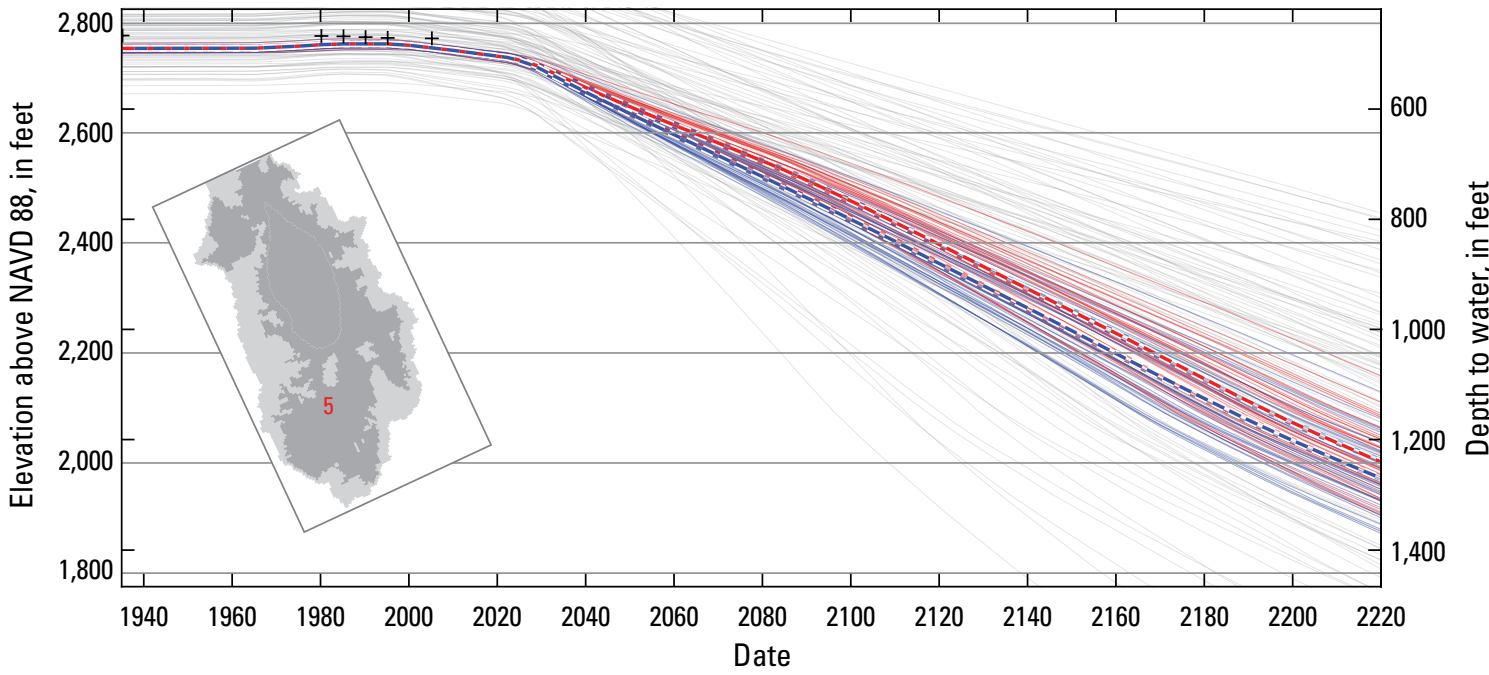

EXPLANATION

Observed and simulated hydraulic heads—Site 5 (surface elevation 3,243 feet)

$+\quad$ Historical observation

Prior ensemble simulation of future withdrawal scenario

Posterior ensemble simulation of future withdrawal scenario

Posterior ensemble simulation of future withdrawal plus enhanced recharge scenario

---- Base posterior ensemble realization for future withdrawal scenario

---- Base posterior ensemble realization for future withdrawal plus enhanced recharge scenario

Fig. 1.1.-Continued 


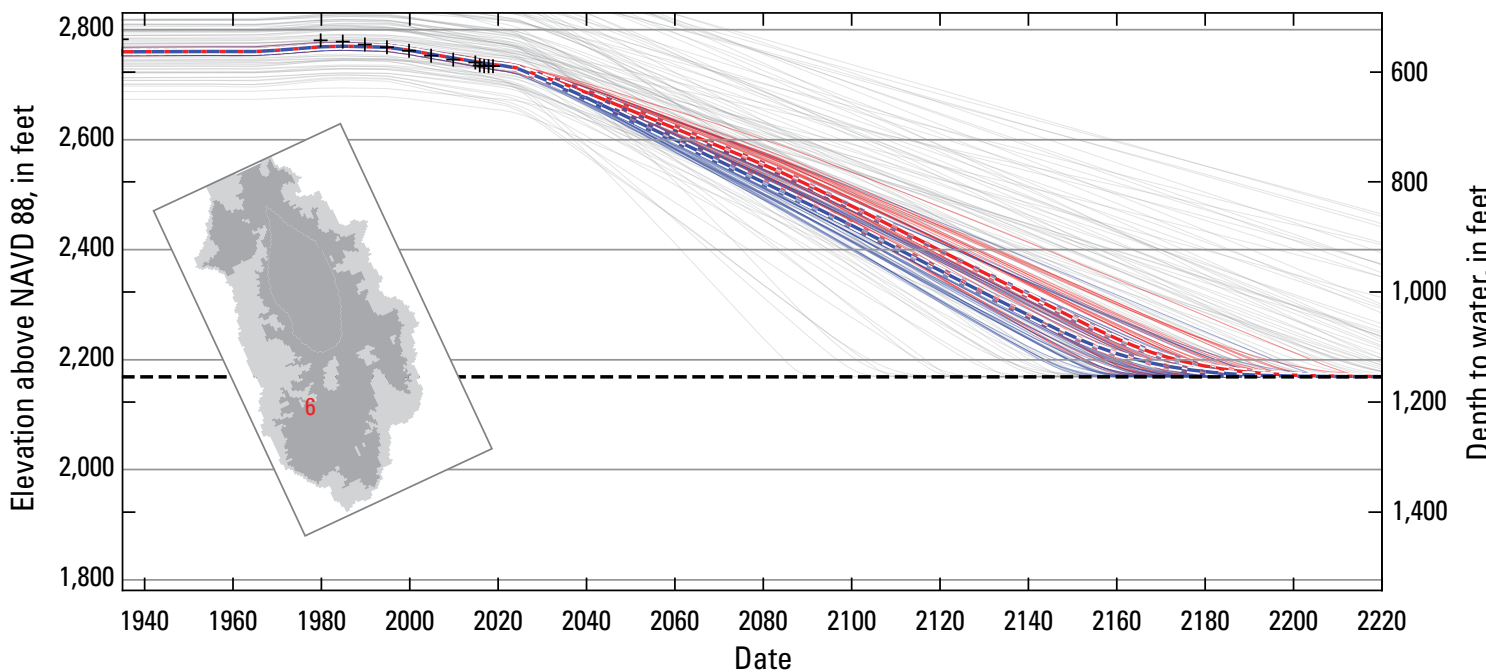

EXPLANATION

Observed and simulated hydraulic heads-Site 6 (surface elevation 3,323 feet)

$+\quad$ Historical observation

Prior ensemble simulation of future withdrawal scenario

Posterior ensemble simulation of future withdrawal scenario

Posterior ensemble simulation of future withdrawal plus enhanced recharge scenario

---- Base posterior ensemble realization for future withdrawal scenario

---- Base posterior ensemble realization for future withdrawal plus enhanced recharge scenario

---- Base elevation of model cell (roughly equal to top of basement elevation)

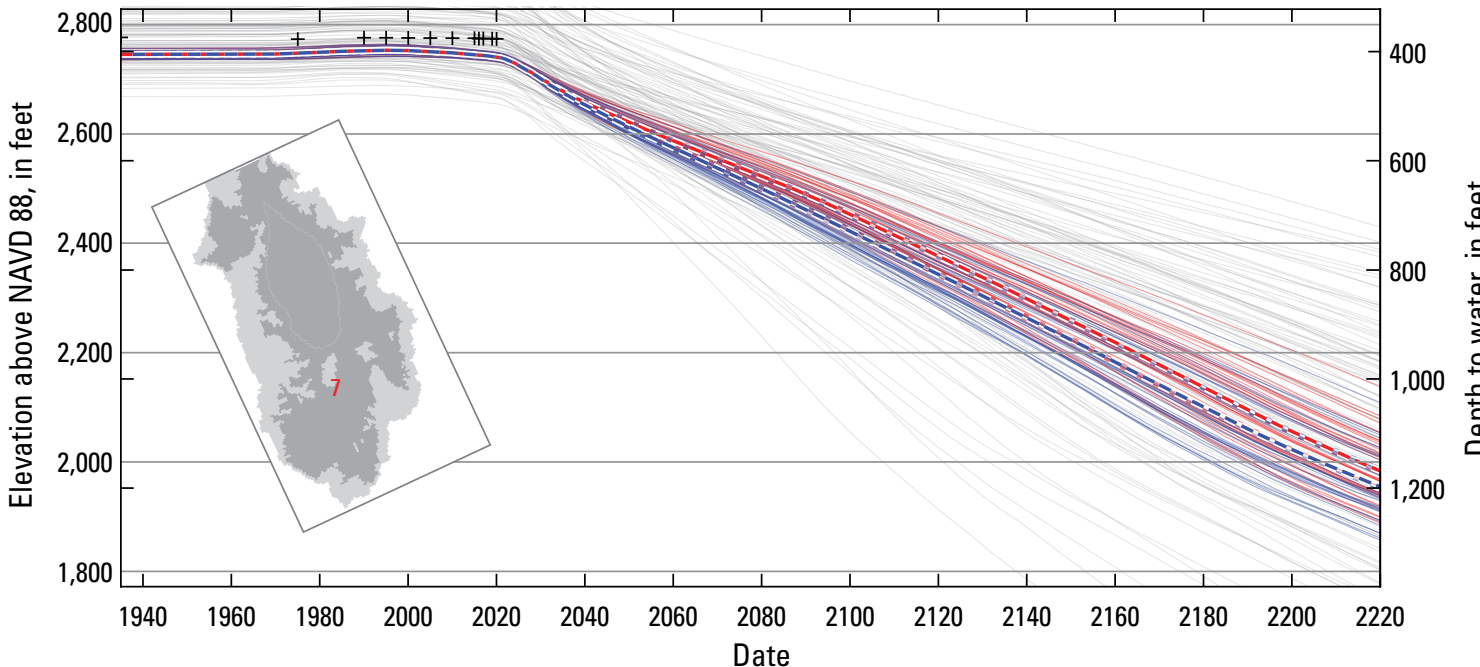

\section{EXPLANATION}

Observed and simulated hydraulic heads - Site 7 (surface elevation 3,152 feet)

$+\quad$ Historical observation

Prior ensemble simulation of future withdrawal scenario

Posterior ensemble simulation of future withdrawal scenario

Posterior ensemble simulation of future withdrawal plus enhanced recharge scenario

---- Base posterior ensemble realization for future withdrawal scenario

--- $\quad$ Base posterior ensemble realization for future withdrawal plus enhanced recharge scenario

Fig. 1.1.-Continued 


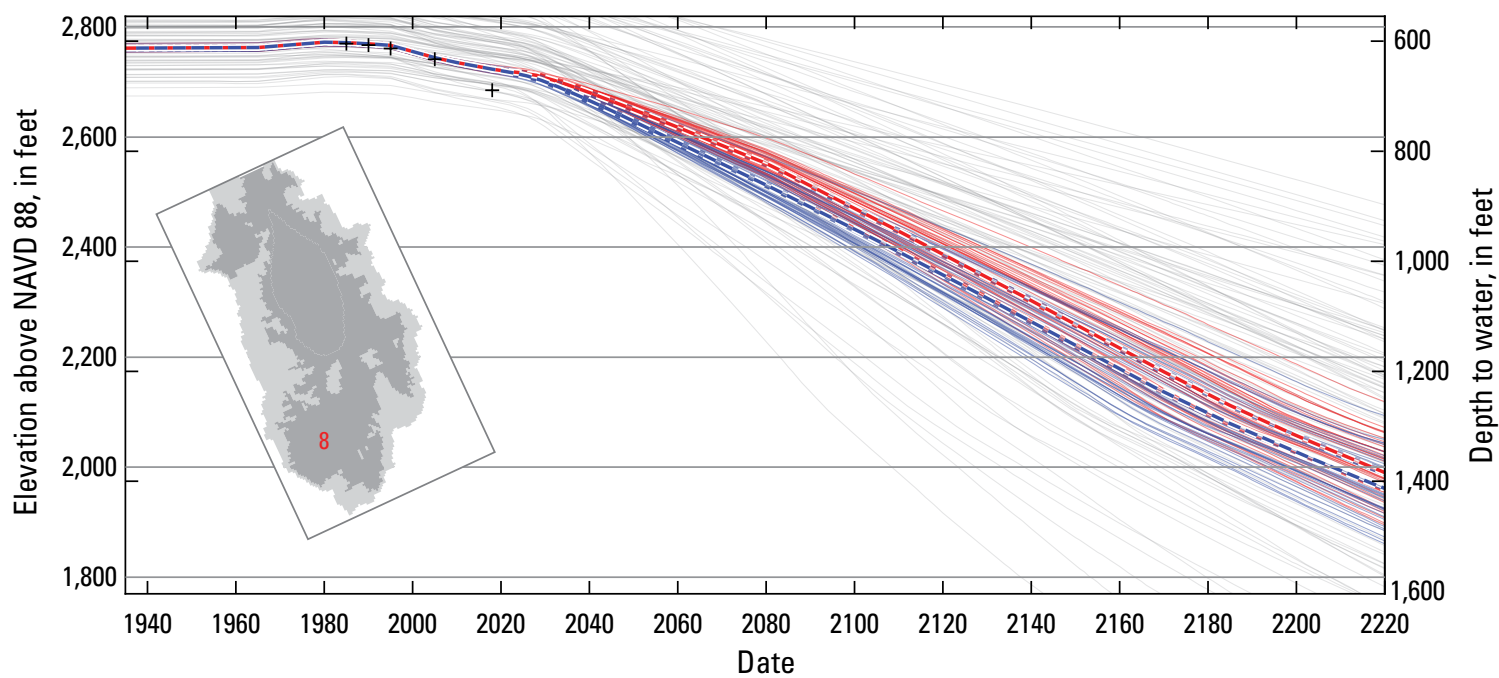

EXPLANATION

Observed and simulated hydraulic heads - Site 8 (surface elevation 3,374 feet)

$+\quad$ Historical observation

Prior ensemble simulation of future withdrawal scenario

Posterior ensemble simulation of future withdrawal scenario

Posterior ensemble simulation of future withdrawal plus enhanced recharge scenario

---- Base posterior ensemble realization for future withdrawal scenario

--_- Base posterior ensemble realization for future withdrawal plus enhanced recharge scenario

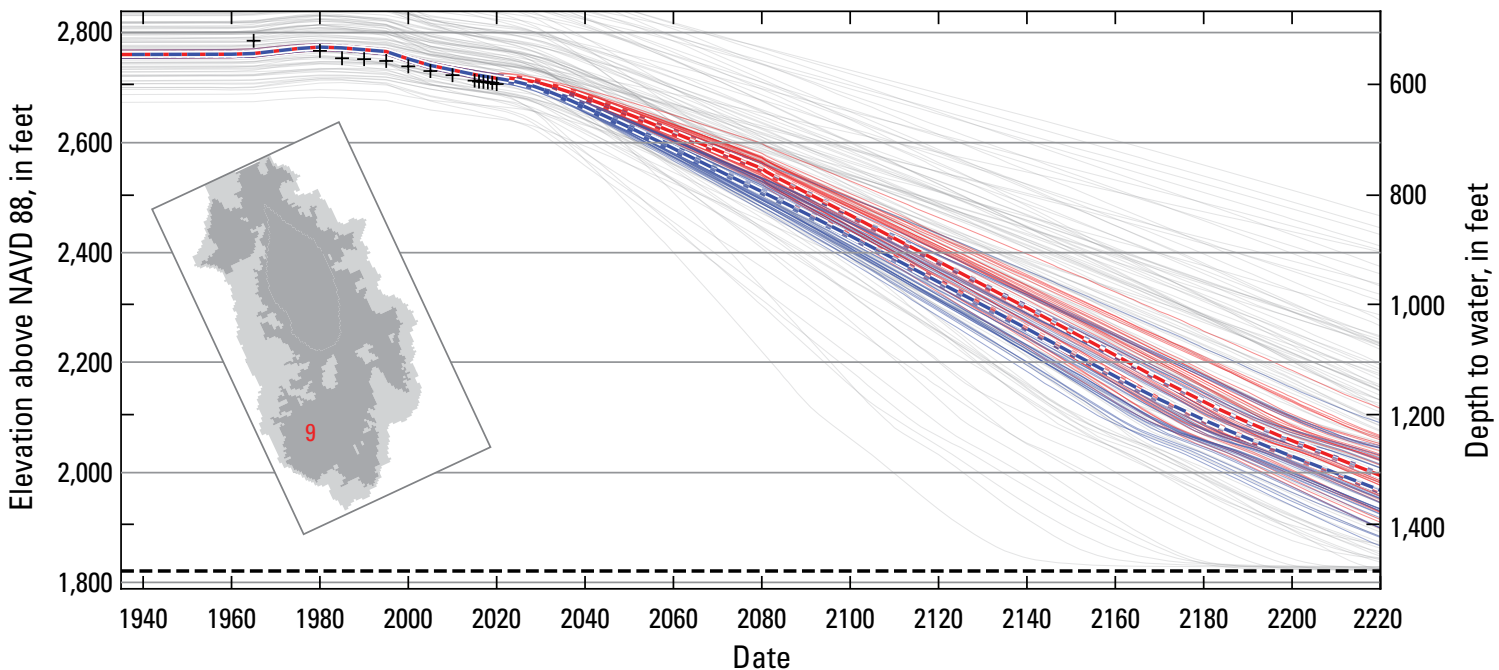

\section{EXPLANATION}

Observed and simulated hydraulic heads - Site 9 (surface elevation 3,306 feet)

$+\quad$ Historical observation

Prior ensemble simulation of future withdrawal scenario

Posterior ensemble simulation of future withdrawal scenario

Posterior ensemble simulation of future withdrawal plus enhanced recharge scenario

---- Base posterior ensemble realization for future withdrawal scenario

---- Base posterior ensemble realization for future withdrawal plus enhanced recharge scenario

Fig. 1.1.-Continued

Base elevation of model cell (roughly equal to top of basement elevation) 


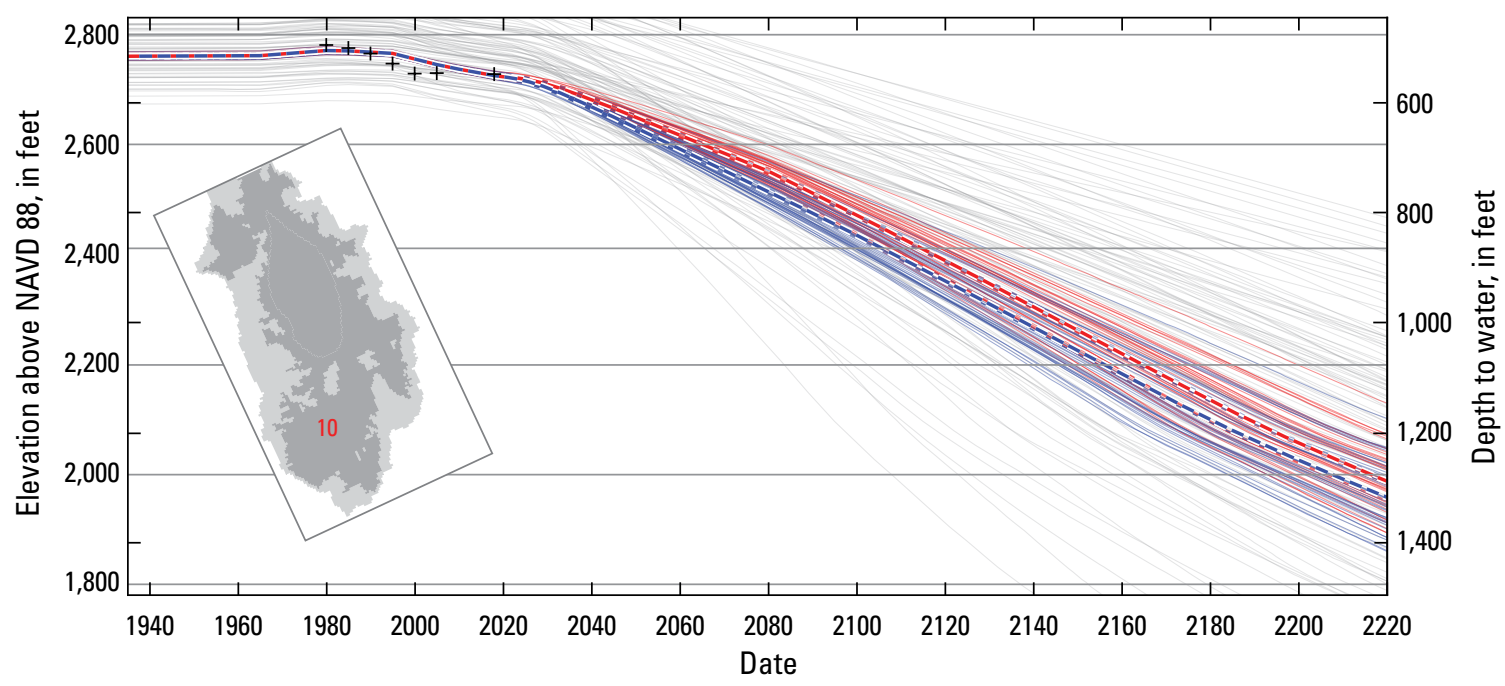

EXPLANATION

Observed and simulated hydraulic heads - Site 10 (surface elevation 3,276 feet)

$+\quad$ Historical observation

Prior ensemble simulation of future withdrawal scenario

Posterior ensemble simulation of future withdrawal scenario

Posterior ensemble simulation of future withdrawal plus enhanced recharge scenario

--- - Base posterior ensemble realization for future withdrawal scenario

---- Base posterior ensemble realization for future withdrawal plus enhanced recharge scenario

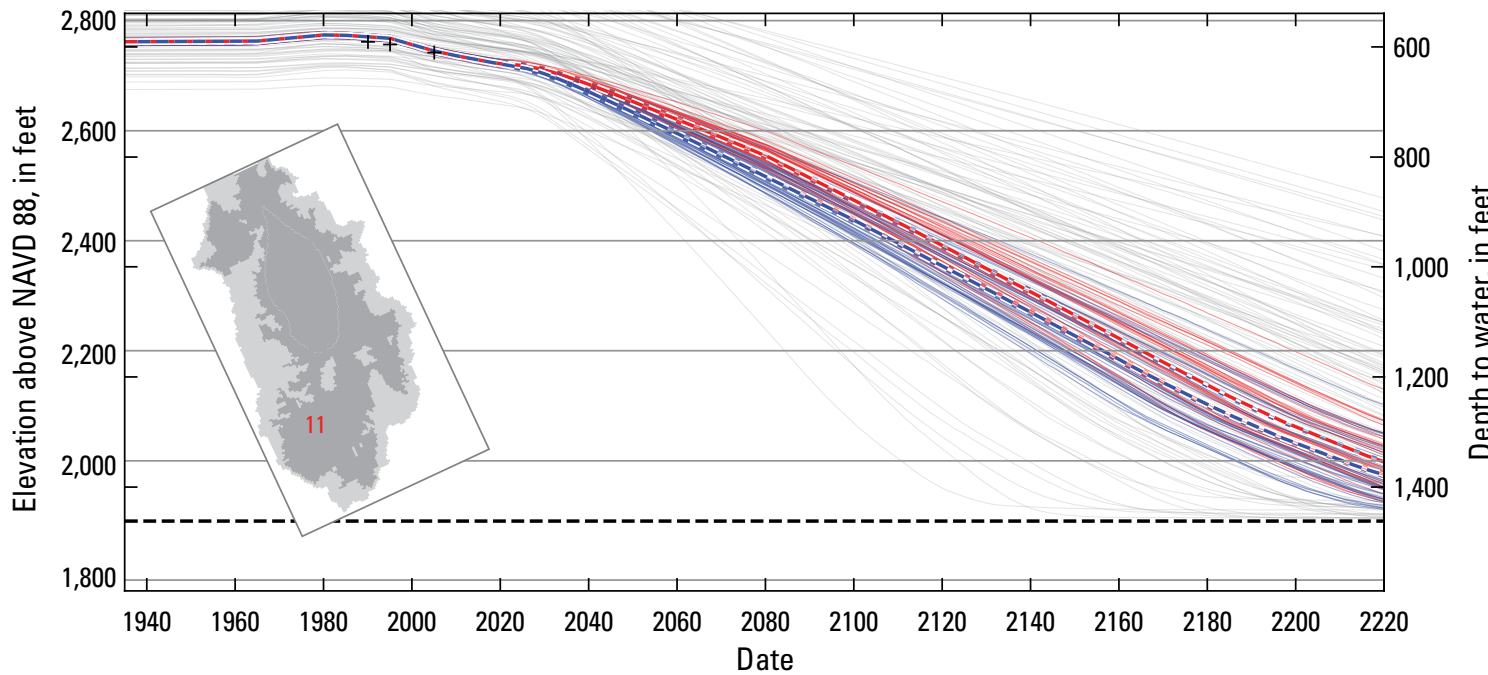

\section{EXPLANATION}

Observed and simulated hydraulic heads - Site 11 (surface elevation 3,352 feet)

Historical observation

Prior ensemble simulation of future withdrawal scenario

Posterior ensemble simulation of future withdrawal scenario

Posterior ensemble simulation of future withdrawal plus enhanced recharge scenario

- - - - Base posterior ensemble realization for future withdrawal scenario

---- Base posterior ensemble realization for future withdrawal plus enhanced recharge scenario

Fig. 1.1.-Continued

Base elevation of model cell (roughly equal to top of basement elevation) 


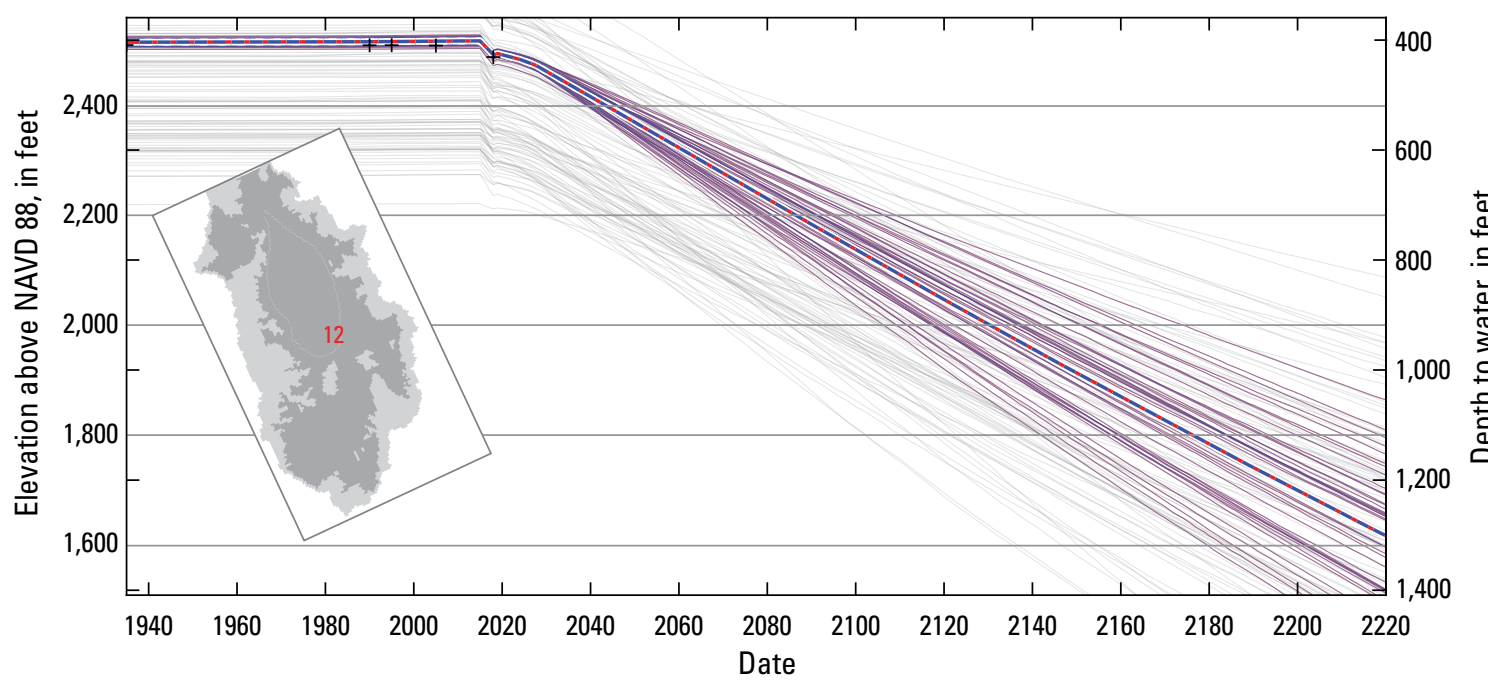

EXPLANATION

Observed and simulated hydraulic heads-Site 12 (surface elevation 2,919 feet)

$+\quad$ Historical observation

Prior ensemble simulation of future withdrawal scenario

Posterior ensemble simulation of future withdrawal scenario

Posterior ensemble simulation of future withdrawal plus enhanced recharge scenario

---- Base posterior ensemble realization for future withdrawal scenario

---- Base posterior ensemble realization for future withdrawal plus enhanced recharge scenario

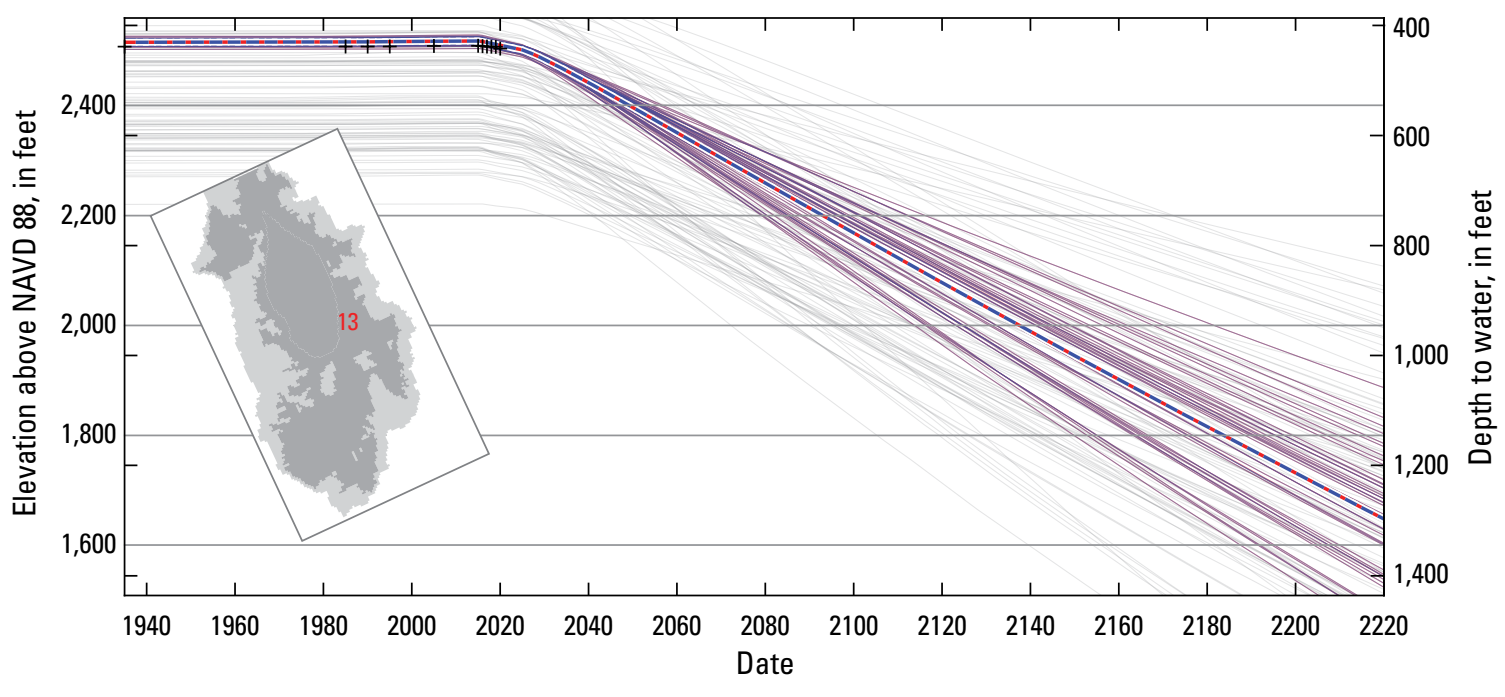

\section{EXPLANATION}

Observed and simulated hydraulic heads-Site 13 (surface elevation 2,945 feet)

$+\quad$ Historical observation

Prior ensemble simulation of future withdrawal scenario

Posterior ensemble simulation of future withdrawal scenario

Posterior ensemble simulation of future withdrawal plus enhanced recharge scenario

---- Base posterior ensemble realization for future withdrawal scenario

---- Base posterior ensemble realization for future withdrawal plus enhanced recharge scenario

Fig. 1.1.-Continued 


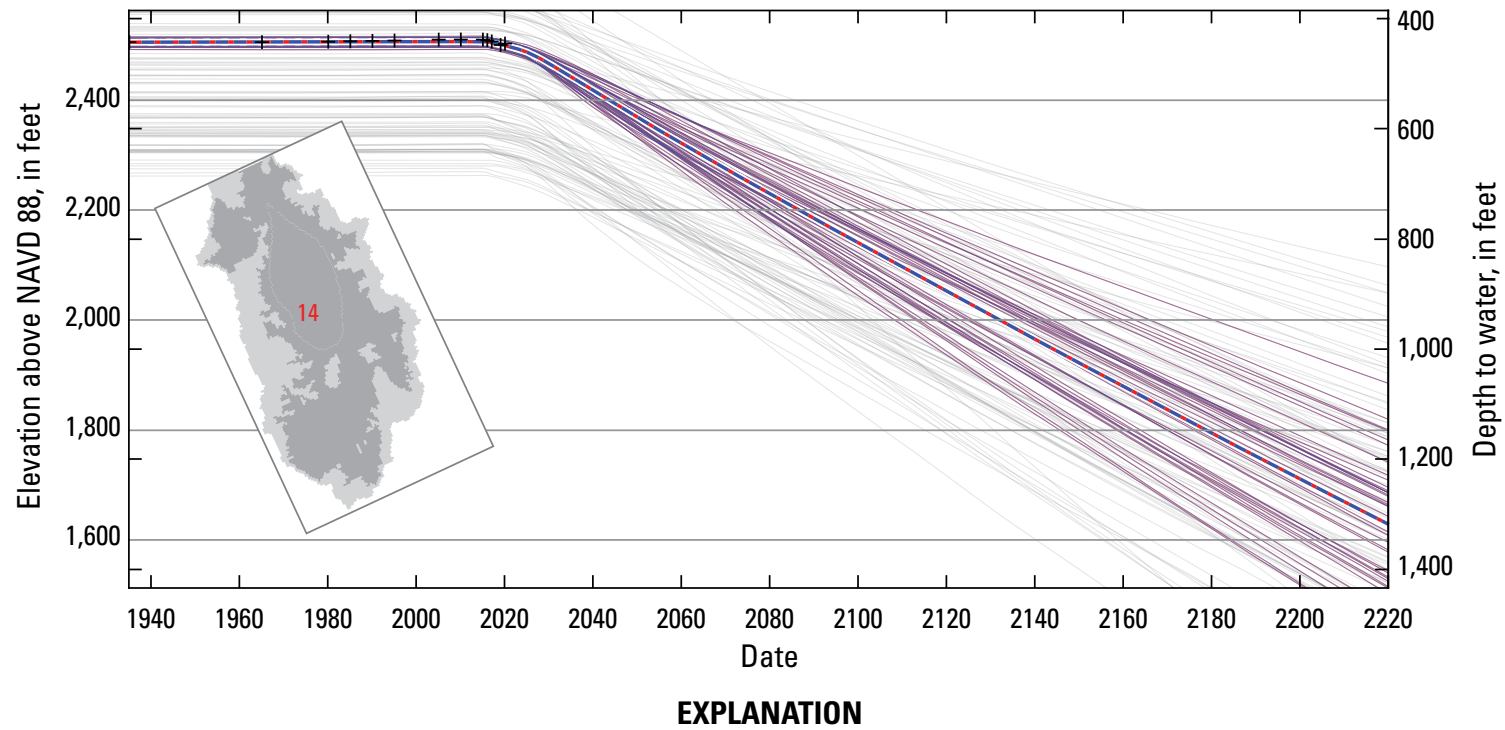

Observed and simulated hydraulic heads—Site 14 (surface elevation 2,948 feet)

Historical observation

Prior ensemble simulation of future withdrawal scenario

Posterior ensemble simulation of future withdrawal scenario

Posterior ensemble simulation of future withdrawal plus enhanced recharge scenario

---- Base posterior ensemble realization for future withdrawal scenario

---- Base posterior ensemble realization for future withdrawal plus enhanced recharge scenario

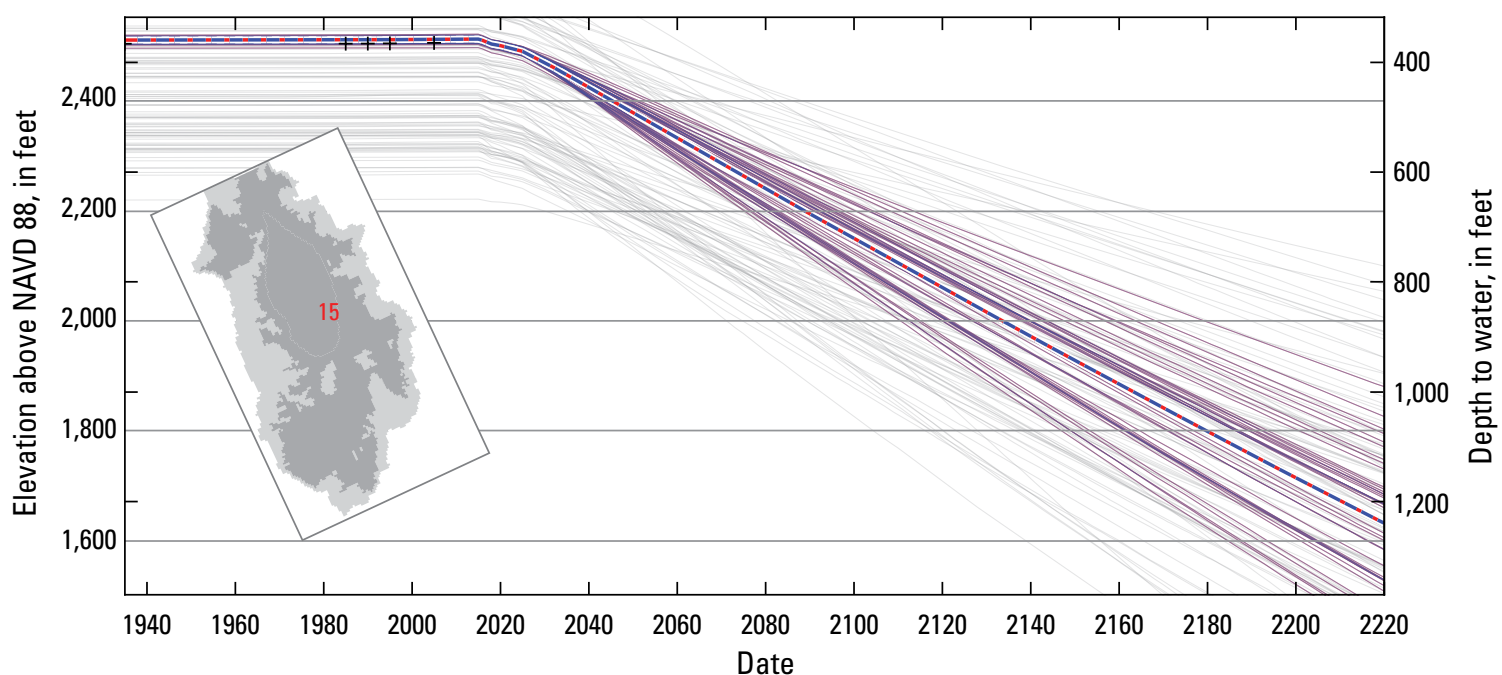

\section{EXPLANATION}

Observed and simulated hydraulic heads-Site 15 (surface elevation 2,870 feet)

$+\quad$ Historical observation

Prior ensemble simulation of future withdrawal scenario

Posterior ensemble simulation of future withdrawal scenario

Posterior ensemble simulation of future withdrawal plus enhanced recharge scenario

--- $\quad$ Base posterior ensemble realization for future withdrawal scenario

Fig. 1.1.-Continued

Base posterior ensemble realization for future withdrawal plus enhanced recharge scenario 


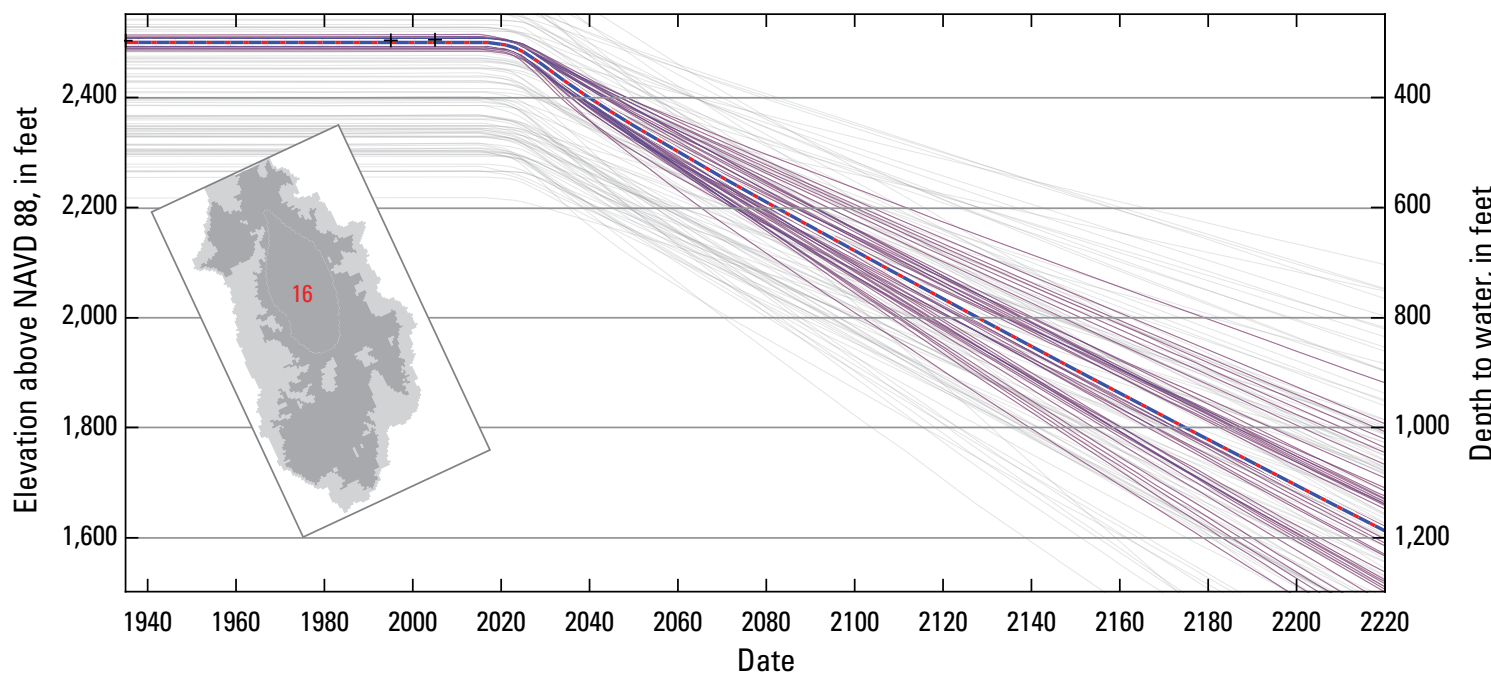

EXPLANATION

Observed and simulated hydraulic heads-Site 16 (surface elevation 2,800 feet)

$+\quad$ Historical observation

Prior ensemble simulation of future withdrawal scenario

Posterior ensemble simulation of future withdrawal scenario

Posterior ensemble simulation of future withdrawal plus enhanced recharge scenario

---- Base posterior ensemble realization for future withdrawal scenario

---- Base posterior ensemble realization for future withdrawal plus enhanced recharge scenario

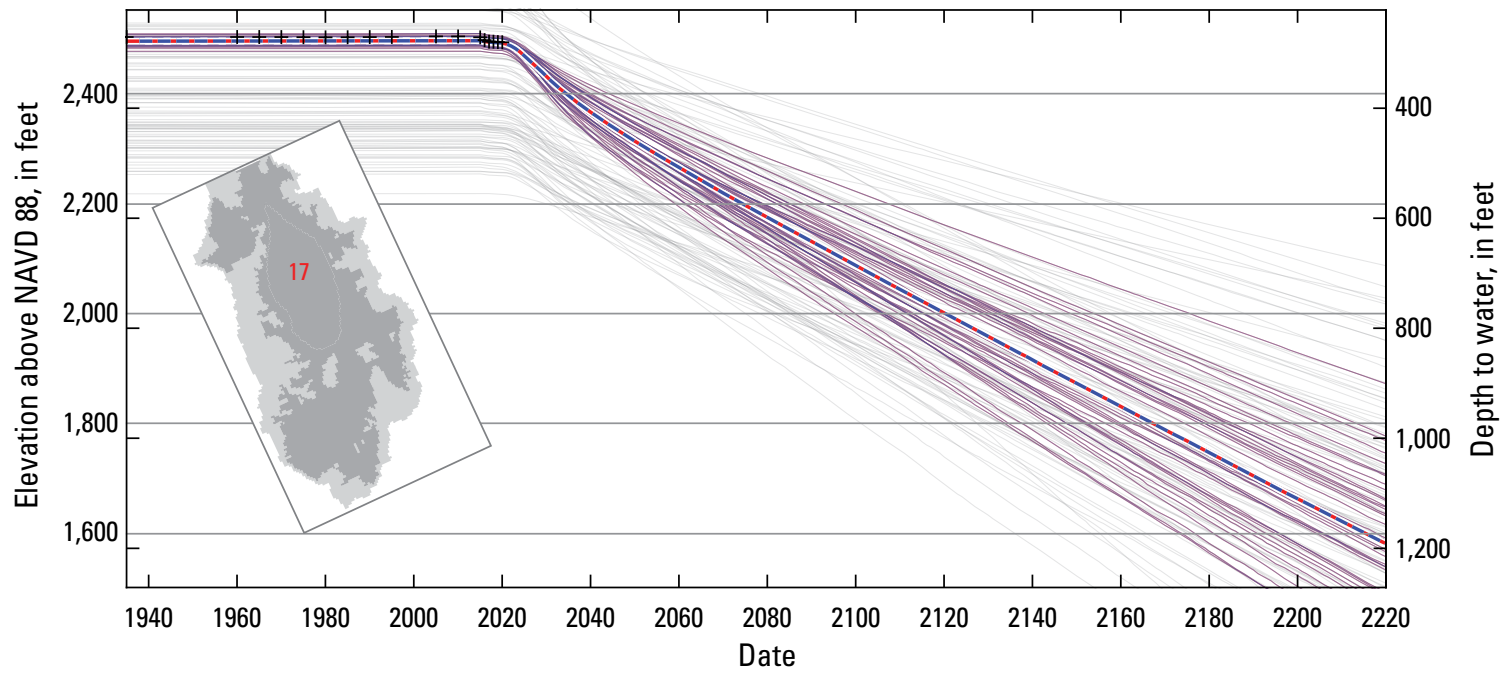

EXPLANATION

Observed and simulated hydraulic heads—Site 17 (surface elevation 2,773 feet)

$+\quad$ Historical observation

Prior ensemble simulation of future withdrawal scenario

Posterior ensemble simulation of future withdrawal scenario

Posterior ensemble simulation of future withdrawal plus enhanced recharge scenario

---- Base posterior ensemble realization for future withdrawal scenario

---- Base posterior ensemble realization for future withdrawal plus enhanced recharge scenario

Fig. 1.1.-Continued 


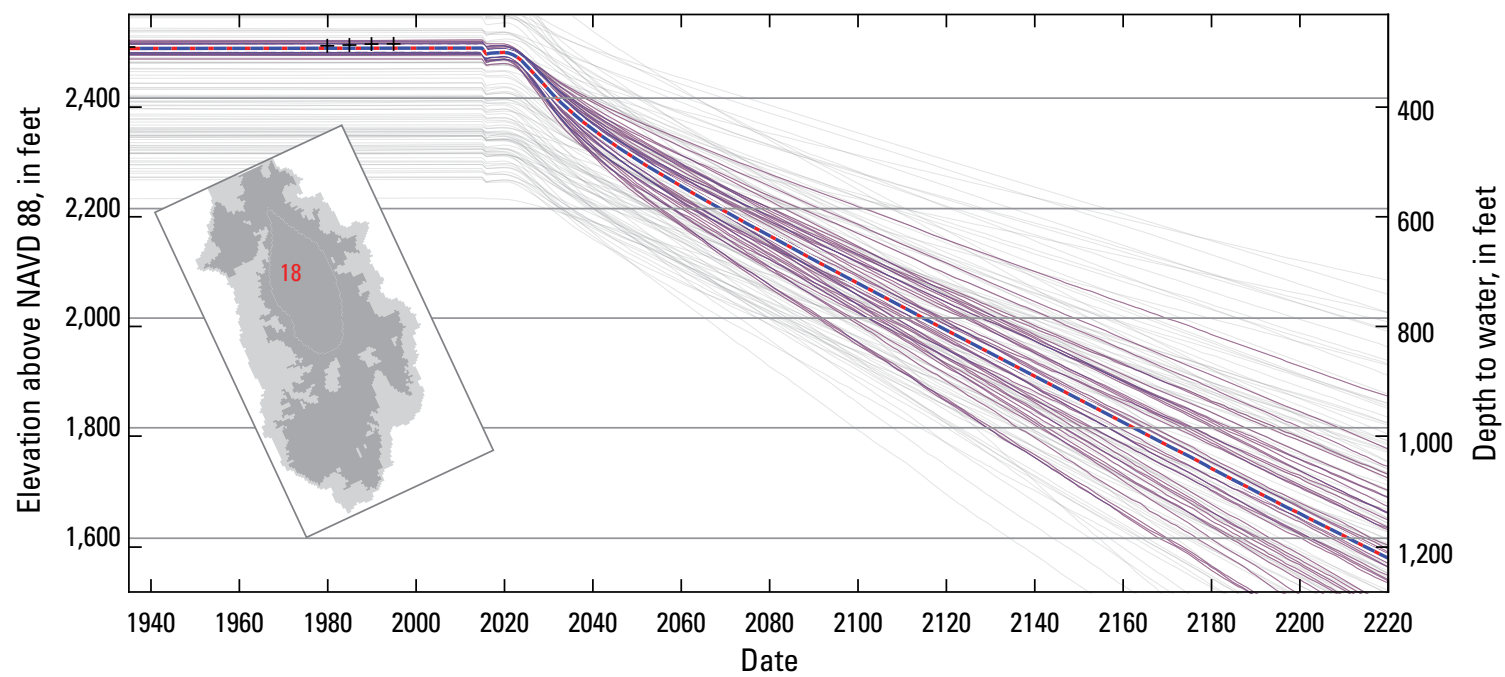

EXPLANATION

Observed and simulated hydraulic heads - Site 18 (surface elevation 2,785 feet)

Historical observation

Prior ensemble simulation of future withdrawal scenario

Posterior ensemble simulation of future withdrawal scenario

Posterior ensemble simulation of future withdrawal plus enhanced recharge scenario

---- Base posterior ensemble realization for future withdrawal scenario

--- - Base posterior ensemble realization for future withdrawal plus enhanced recharge scenario

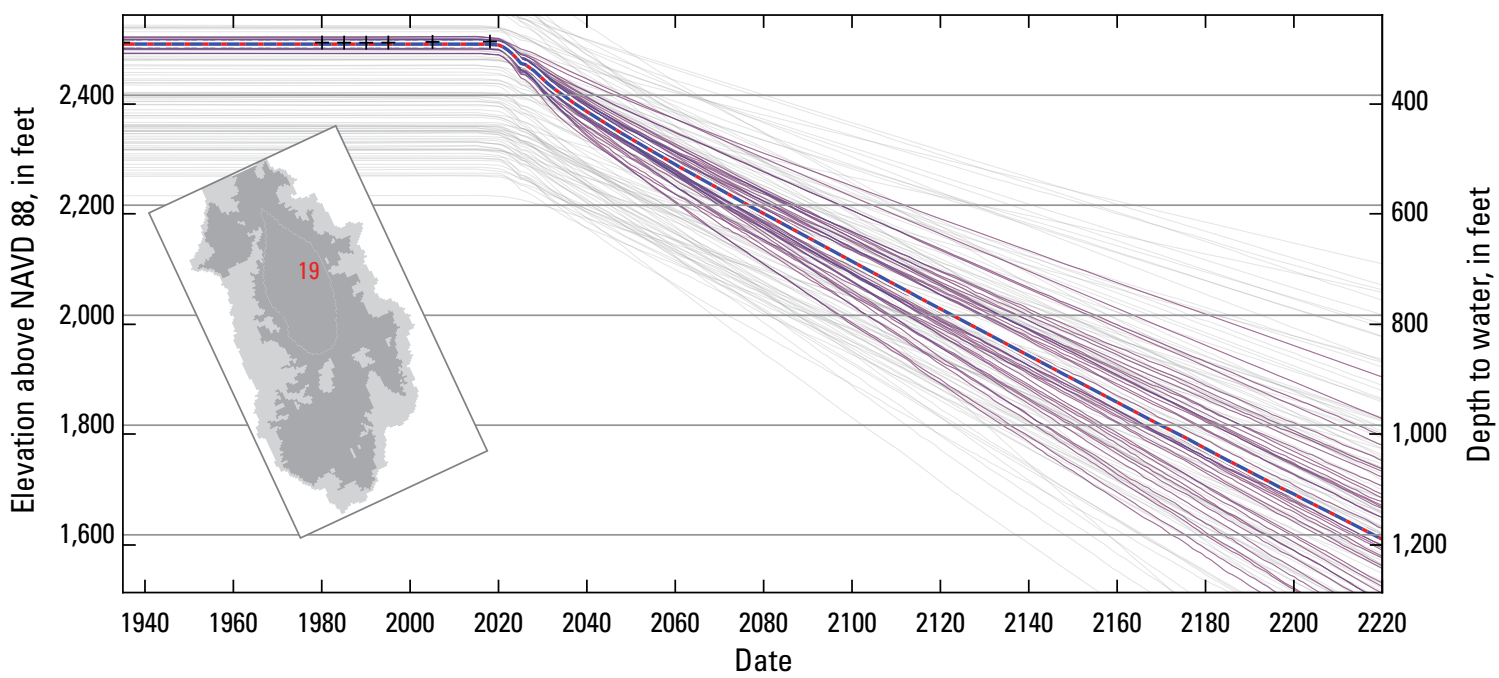

\section{EXPLANATION}

Observed and simulated hydraulic heads - Site 19 (surface elevation 2,784 feet)

$+\quad$ Historical observation

Prior ensemble simulation of future withdrawal scenario

Posterior ensemble simulation of future withdrawal scenario

Posterior ensemble simulation of future withdrawal plus enhanced recharge scenario

Base posterior ensemble realization for future withdrawal scenario

Base posterior ensemble realization for future withdrawal plus enhanced recharge scenario

Fig. 1.1.-Continued 


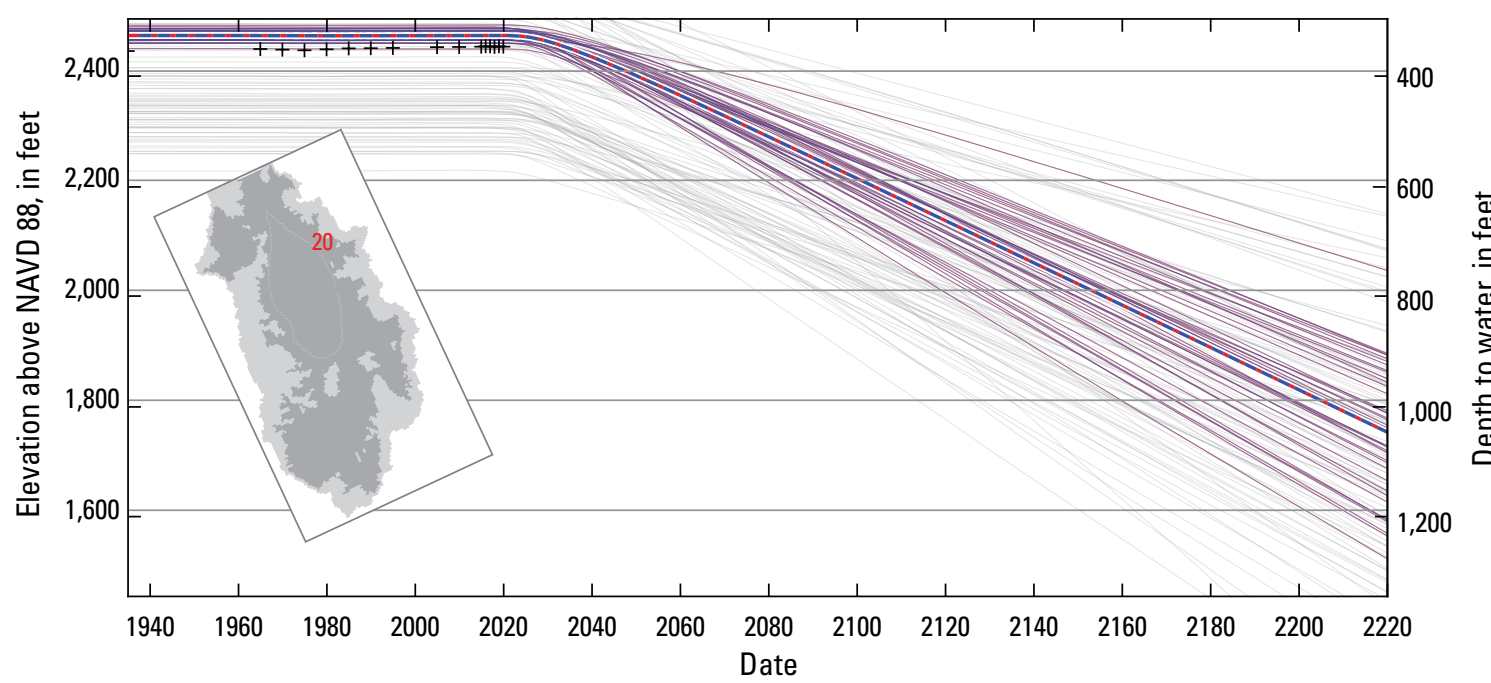

EXPLANATION

Observed and simulated hydraulic heads-Site 20 (surface elevation 2,790 feet)

$+\quad$ Historical observation

Prior ensemble simulation of future withdrawal scenario

Posterior ensemble simulation of future withdrawal scenario

Posterior ensemble simulation of future withdrawal plus enhanced recharge scenario

---- Base posterior ensemble realization for future withdrawal scenario

---- Base posterior ensemble realization for future withdrawal plus enhanced recharge scenario

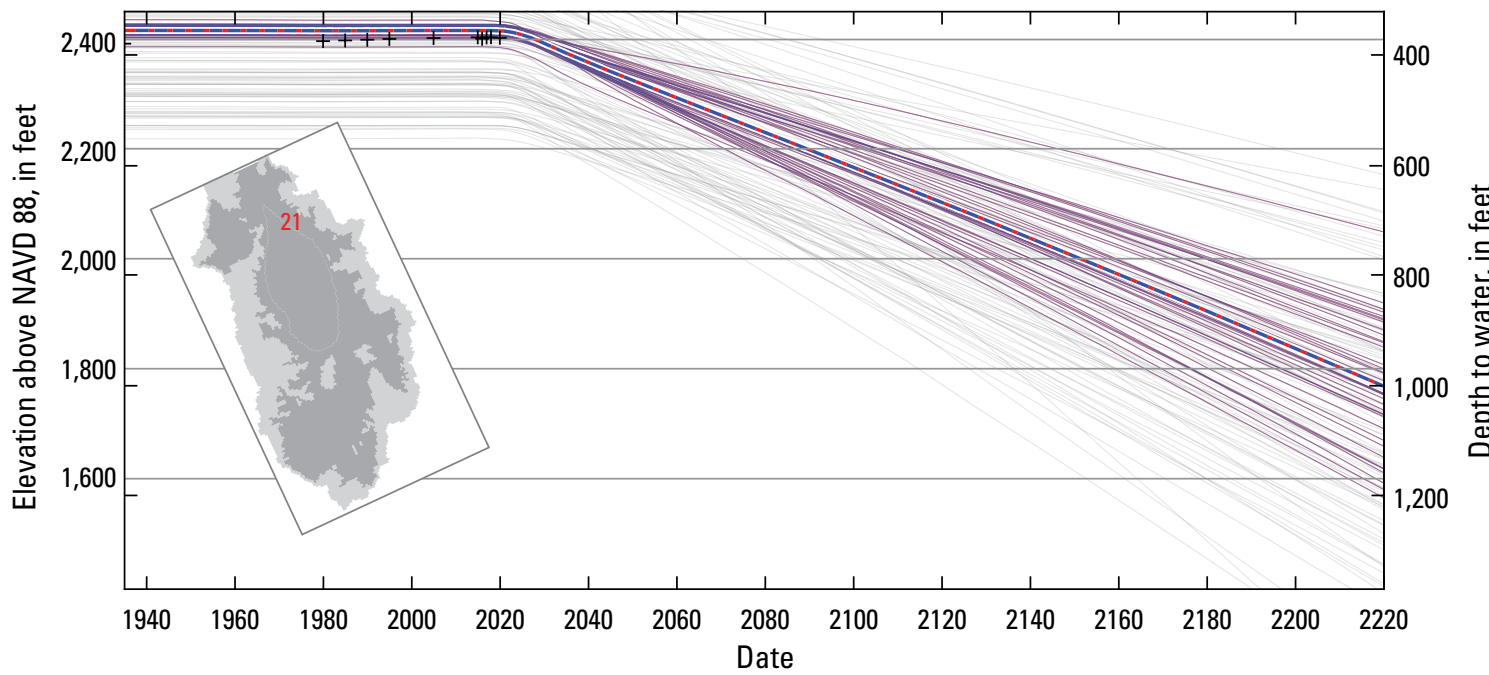

EXPLANATION

Observed and simulated hydraulic heads-Site 21 (surface elevation 2,769 feet)

$+\quad$ Historical observation

Prior ensemble simulation of future withdrawal scenario

Posterior ensemble simulation of future withdrawal scenario

Posterior ensemble simulation of future withdrawal plus enhanced recharge scenario

--- Base posterior ensemble realization for future withdrawal scenario

---- Base posterior ensemble realization for future withdrawal plus enhanced recharge scenario

Fig. 1.1.-Continued 


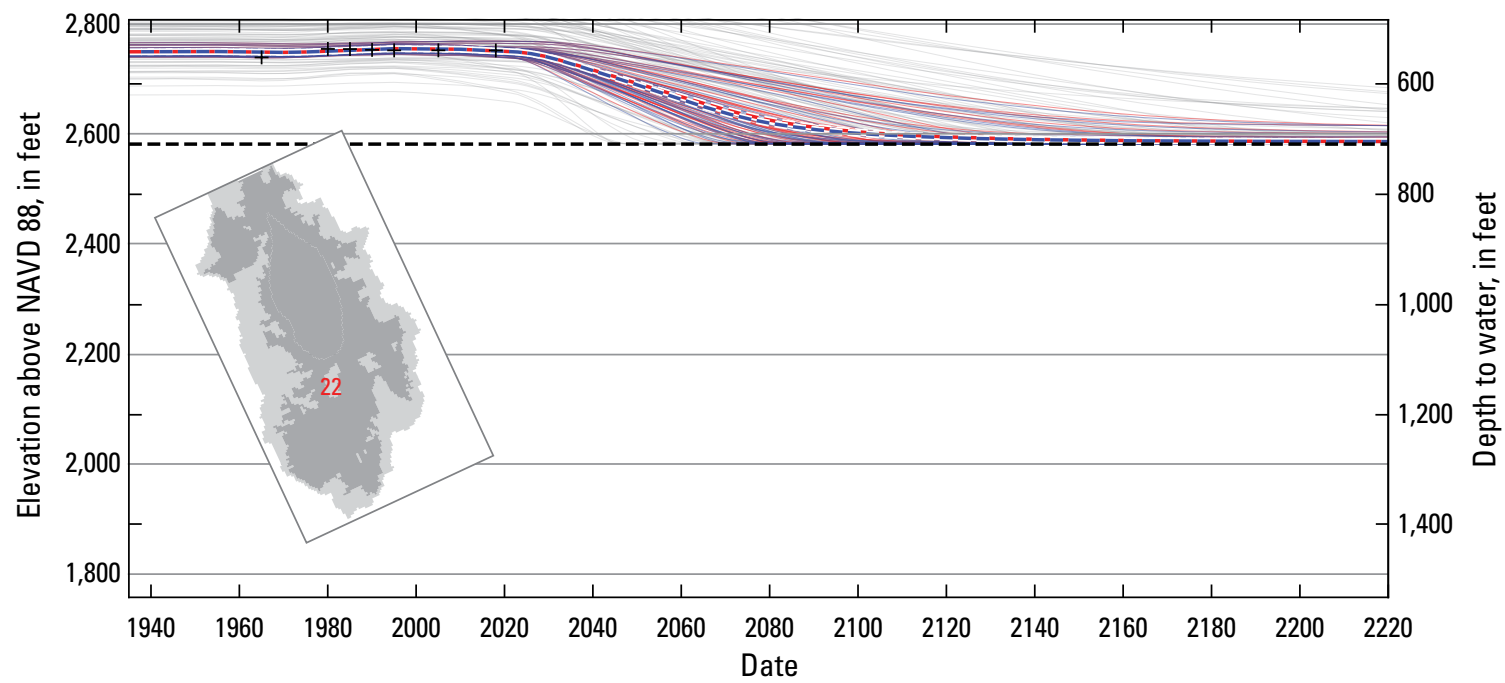

EXPLANATION

Observed and simulated hydraulic heads-Site 22 (surface elevation 3,290 feet)

$+\quad$ Historical observation

Prior ensemble simulation of future withdrawal scenario

Posterior ensemble simulation of future withdrawal scenario

Posterior ensemble simulation of future withdrawal plus enhanced recharge scenario

---- Base posterior ensemble realization for future withdrawal scenario

--- Base posterior ensemble realization for future withdrawal plus enhanced recharge scenario

---- Base elevation of model cell (roughly equal to top of basement elevation)

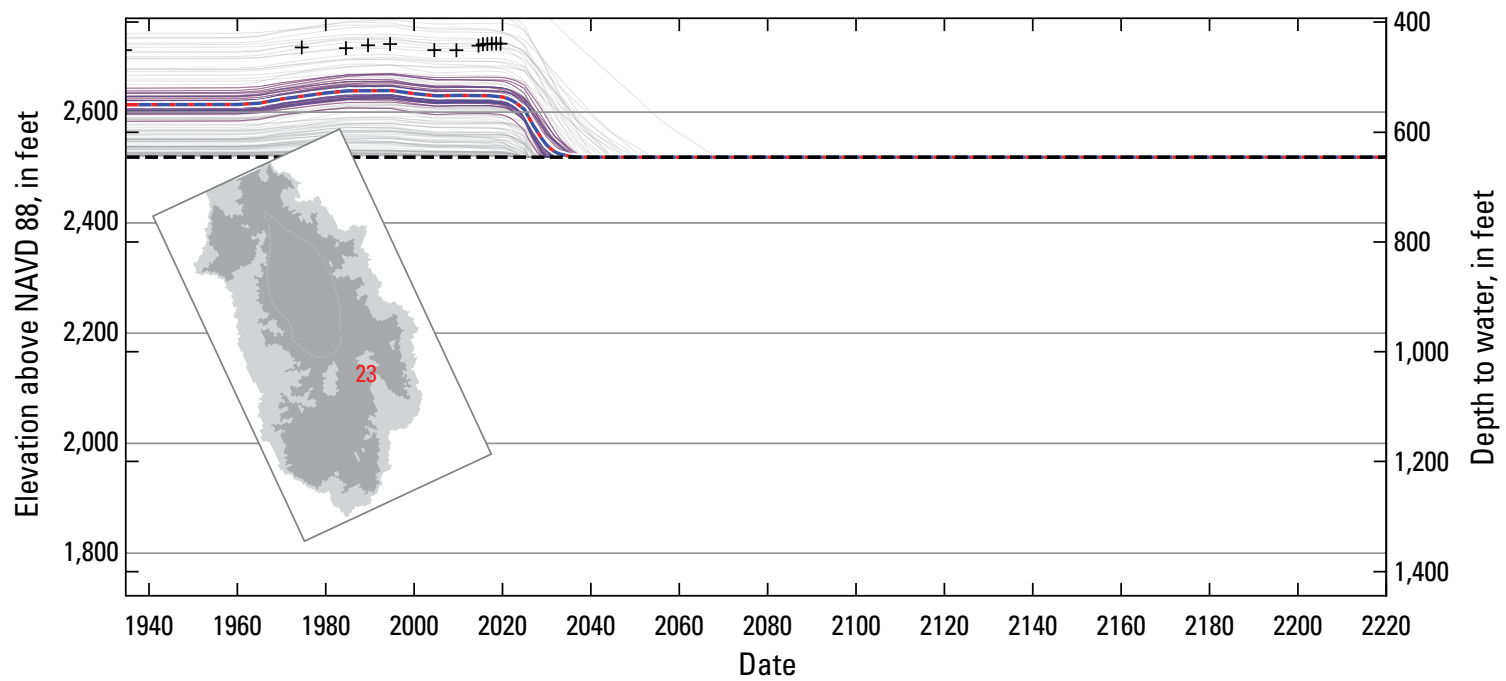

EXPLANATION

Observed and simulated hydraulic heads-Site 23 (surface elevation 3,165 feet)

$+\quad$ Historical observation

Prior ensemble simulation of future withdrawal scenario

Posterior ensemble simulation of future withdrawal scenario

Posterior ensemble simulation of future withdrawal plus enhanced recharge scenario

---- Base posterior ensemble realization for future withdrawal scenario

---- Base posterior ensemble realization for future withdrawal plus enhanced recharge scenario

Fig. 1.1.-Continued

---- Base elevation of model cell (roughly equal to top of basement elevation) 


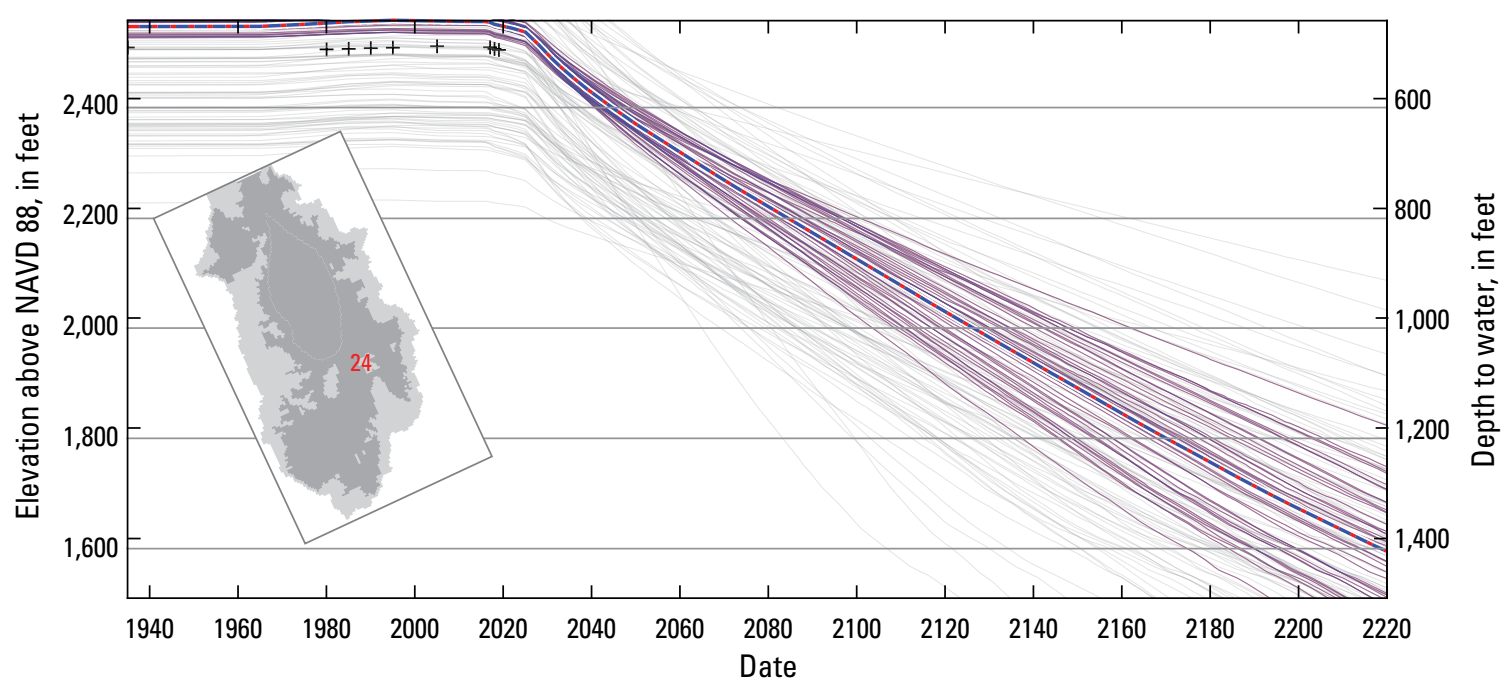

EXPLANATION

Observed and simulated hydraulic heads - Site 24 (surface elevation 3,019 feet)

$+\quad$ Historical observation

Prior ensemble simulation of future withdrawal scenario

Posterior ensemble simulation of future withdrawal scenario

Posterior ensemble simulation of future withdrawal plus enhanced recharge scenario

---- Base posterior ensemble realization for future withdrawal scenario

---- Base posterior ensemble realization for future withdrawal plus enhanced recharge scenario

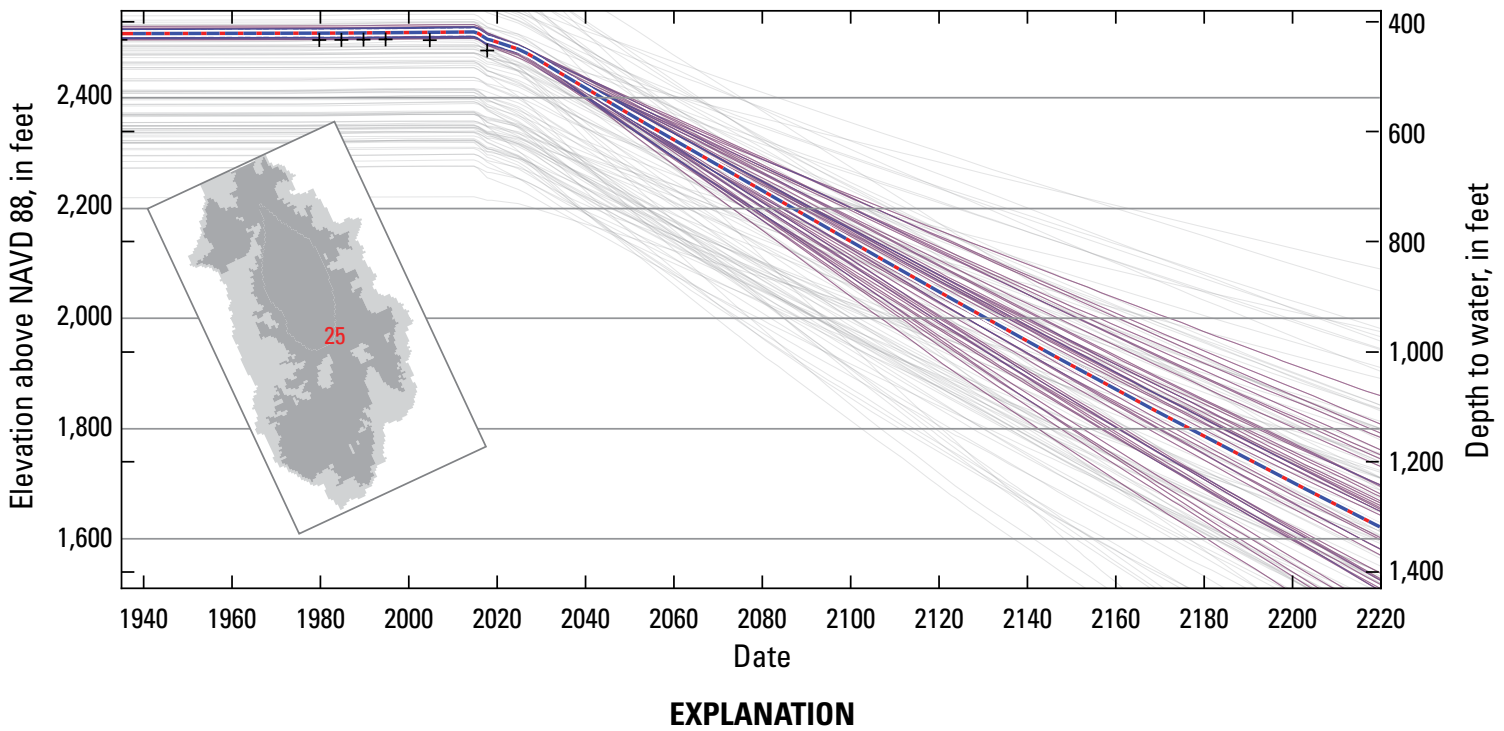

Observed and simulated hydraulic heads - Site 25 (surface elevation 2,940 feet)

$+\quad$ Historical observation

Prior ensemble simulation of future withdrawal scenario

Posterior ensemble simulation of future withdrawal scenario

Posterior ensemble simulation of future withdrawal plus enhanced recharge scenario

Base posterior ensemble realization for future withdrawal scenario

Base posterior ensemble realization for future withdrawal plus enhanced recharge scenario

Fig. 1.1.-Continued 


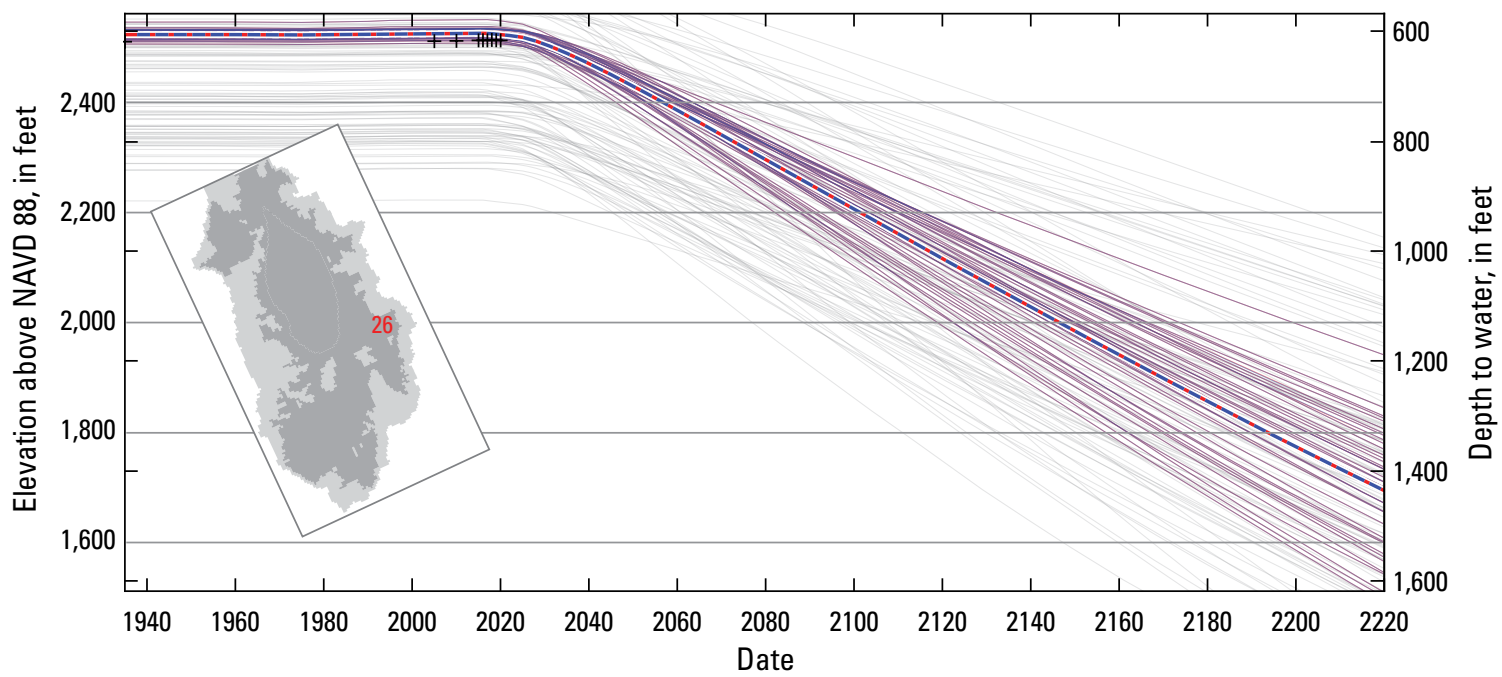

EXPLANATION

Observed and simulated hydraulic heads-Site 26 (surface elevation 3,130 feet)

$+\quad$ Historical observation

Prior ensemble simulation of future withdrawal scenario

Posterior ensemble simulation of future withdrawal scenario

Posterior ensemble simulation of future withdrawal plus enhanced recharge scenario

---- Base posterior ensemble realization for future withdrawal scenario

---- Base posterior ensemble realization for future withdrawal plus enhanced recharge scenario

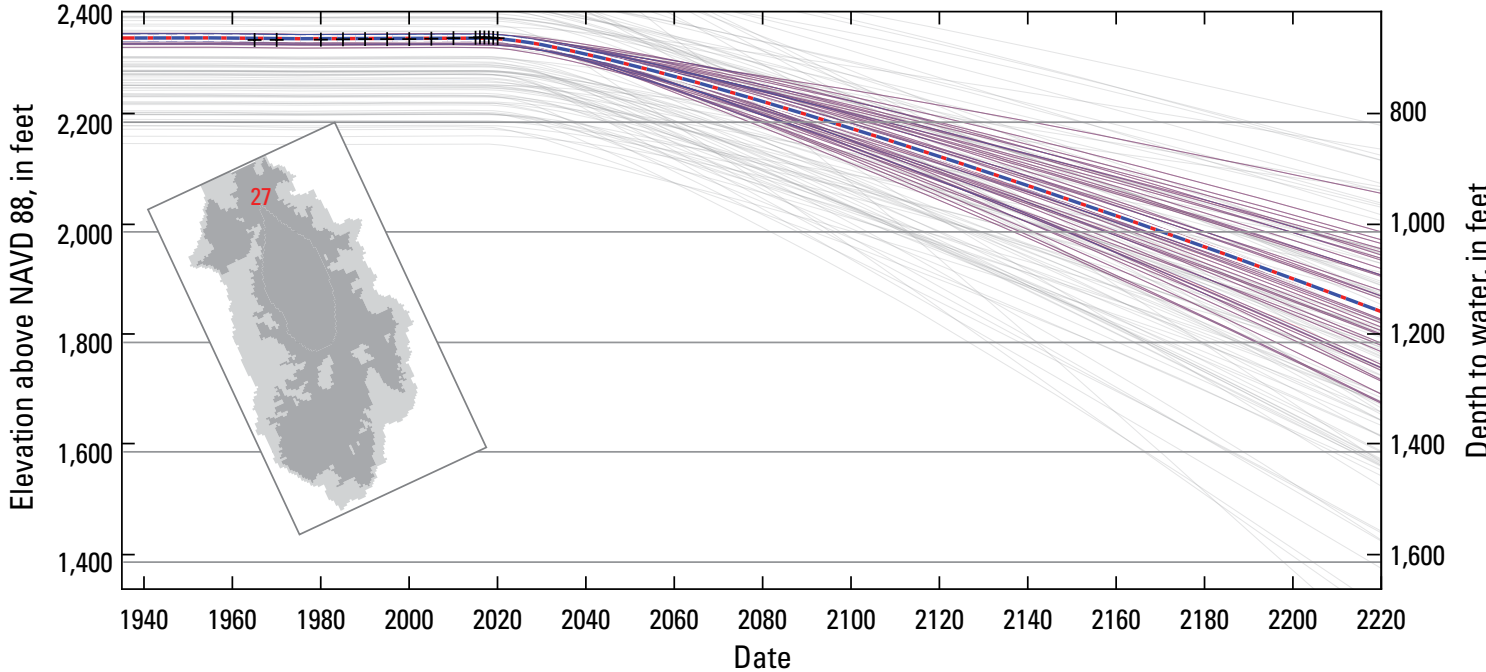

\section{EXPLANATION}

Observed and simulated hydraulic heads - Site 27 (surface elevation 3,015 feet)

$+\quad$ Historical observation

Prior ensemble simulation of future withdrawal scenario

Posterior ensemble simulation of future withdrawal scenario

Posterior ensemble simulation of future withdrawal plus enhanced recharge scenario

---- Base posterior ensemble realization for future withdrawal scenario

---- Base posterior ensemble realization for future withdrawal plus enhanced recharge scenario

Fig. 1.1.-Continued 


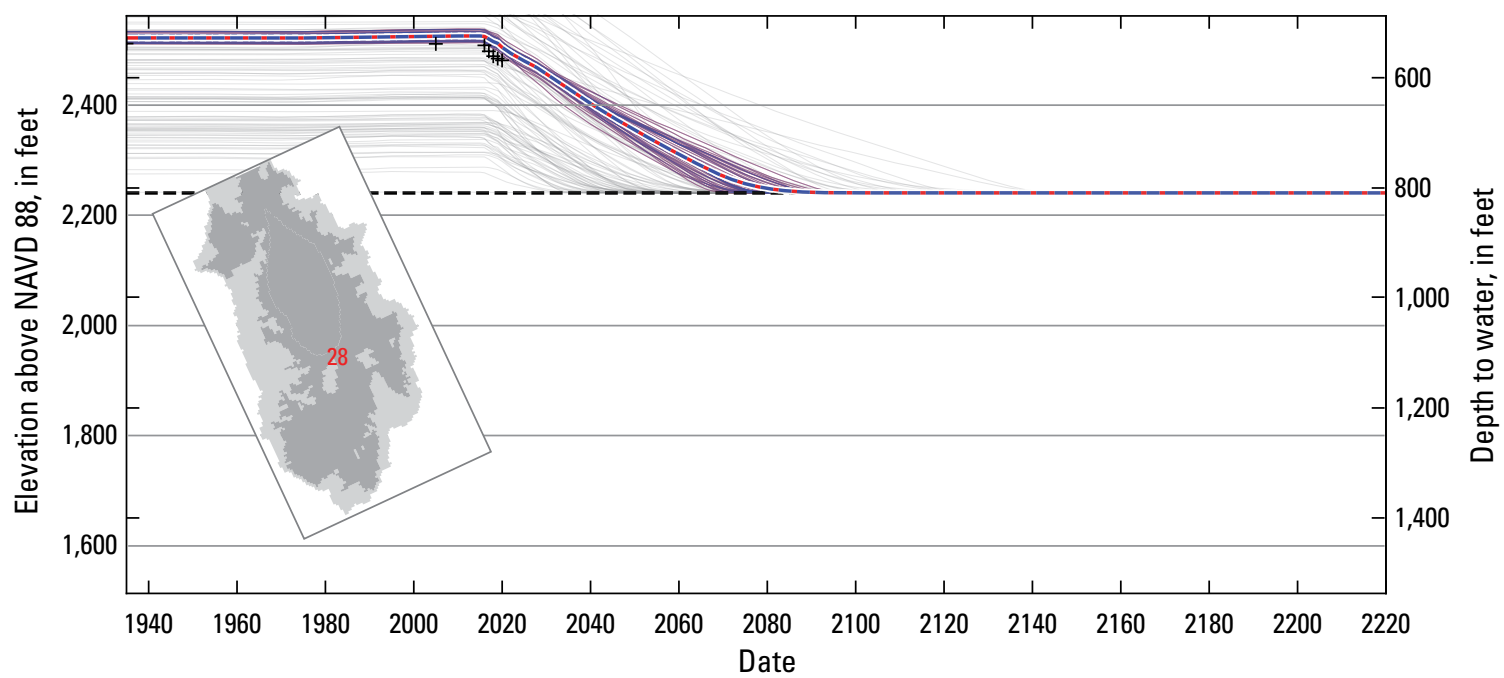

EXPLANATION

Observed and simulated hydraulic heads - Site 28 (surface elevation 3,051 feet)

$+\quad$ Historical observation

Prior ensemble simulation of future withdrawal scenario

Posterior ensemble simulation of future withdrawal scenario

Posterior ensemble simulation of future withdrawal plus enhanced recharge scenario

---- Base posterior ensemble realization for future withdrawal scenario

---- Base posterior ensemble realization for future withdrawal plus enhanced recharge scenario

---- Base elevation of model cell (roughly equal to top of basement elevation)

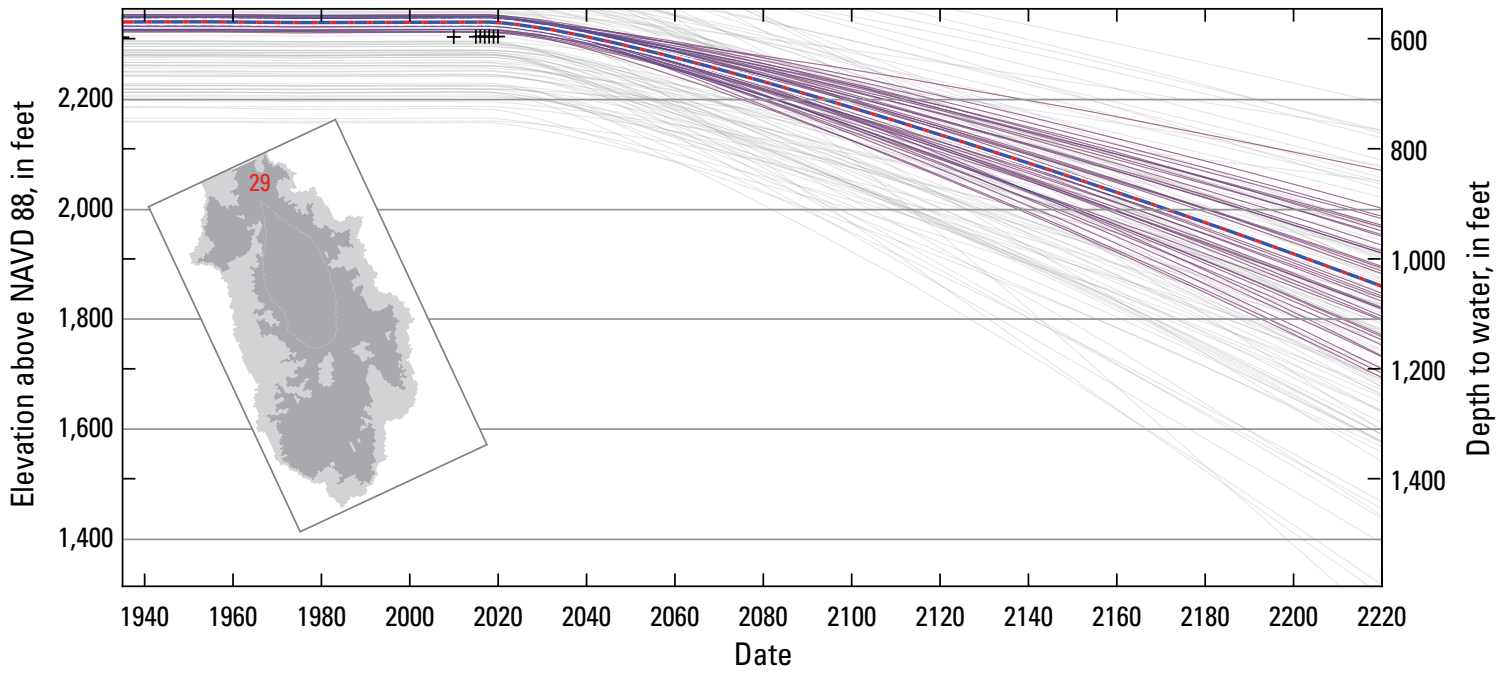

\section{EXPLANATION}

Observed and simulated hydraulic heads - Site 29 (surface elevation 2,910 feet)

$+\quad$ Historical observation

Prior ensemble simulation of future withdrawal scenario

Posterior ensemble simulation of future withdrawal scenario

Posterior ensemble simulation of future withdrawal plus enhanced recharge scenario

Base posterior ensemble realization for future withdrawal scenario

Base posterior ensemble realization for future withdrawal plus enhanced recharge scenario

Fig. 1.1.-Continued 
Table 1.1. Summary of forecasted groundwater hydraulic heads in years 2050 and 2080 at select locations, all units in feet.

[ft, feet; St. dev., standard deviation; \%, percent; - , no data]

\begin{tabular}{|c|c|c|c|c|c|c|c|c|c|c|c|}
\hline \multirow{3}{*}{$\begin{array}{c}\text { Map ID } \\
\text { (figure 20) }\end{array}$} & \multirow{3}{*}{ Year } & \multicolumn{6}{|c|}{ Future withdrawal scenario } & \multirow{2}{*}{\multicolumn{3}{|c|}{$\begin{array}{c}\text { Future withdrawal scenario + } \\
\text { enhanced infiltration scenario } \\
\text { Posterior }\end{array}$}} & \multirow{3}{*}{$\begin{array}{l}\text { Difference } \\
\text { in declines } \\
\text { from } 2020 \\
\text { levels (ft) }\end{array}$} \\
\hline & & \multicolumn{2}{|c|}{ Prior } & \multicolumn{4}{|c|}{ Posterior } & & & & \\
\hline & & $\begin{array}{l}\text { Mean } \\
\text { elevation } \\
\text { (ft) }\end{array}$ & $\begin{array}{r}\text { St. } \\
\text { dev. } \\
\text { (ft) }\end{array}$ & $\begin{array}{c}\text { Mean } \\
\text { elevation } \\
\text { (ft) }\end{array}$ & $\begin{array}{l}\text { St. } \\
\text { dev. } \\
\text { (ft) }\end{array}$ & $\begin{array}{l}\text { Decline } \\
\text { from } 2020 \\
\text { levels (ft) }\end{array}$ & $\begin{array}{l}\text { Uncertainty } \\
\text { reduction } \\
(\%)\end{array}$ & $\begin{array}{c}\text { Mean } \\
\text { elevation } \\
\text { (ft) }\end{array}$ & $\begin{array}{l}\text { St. } \\
\text { dev. } \\
\text { (ft) }\end{array}$ & $\begin{array}{l}\text { Decline } \\
\text { from } 2020 \\
\text { levels (ft) }\end{array}$ & \\
\hline 1 & 2020 & 2,423 & 101 & 2,489 & 7 & - & 94 & 2,489 & 7 & - & - \\
\hline 1 & 2050 & 2,261 & 100 & 2,280 & 39 & 210 & 65 & 2,280 & 39 & 210 & 0 \\
\hline 1 & 2080 & 2,137 & 112 & 2,139 & 54 & 350 & 53 & 2,139 & 54 & 350 & 0 \\
\hline 2 & 2020 & 2,412 & 104 & 2,485 & 8 & - & 96 & 2,485 & 8 & - & - \\
\hline 2 & 2050 & 2,277 & 105 & 2,354 & 20 & 130 & 87 & 2,354 & 20 & 130 & 0 \\
\hline 2 & 2080 & 2,143 & 117 & 2,213 & 39 & 272 & 77 & 2,213 & 39 & 272 & 0 \\
\hline 3 & 2020 & 2,772 & 69 & 2,747 & 12 & - & 82 & 2,747 & 12 & - & - \\
\hline 3 & 2050 & 2,666 & 81 & 2,630 & 11 & 117 & 80 & 2,648 & 9 & 98 & 18 \\
\hline 3 & 2080 & 2,554 & 106 & 2,513 & 19 & 233 & 75 & 2,549 & 17 & 198 & 36 \\
\hline 4 & 2020 & 2,746 & 64 & 2,715 & 4 & - & 93 & 2,715 & 4 & - & - \\
\hline 4 & 2050 & 2,660 & 80 & 2,628 & 10 & 87 & 85 & 2,651 & 9 & 64 & 23 \\
\hline 4 & 2080 & 2,548 & 108 & 2,511 & 19 & 204 & 77 & 2,554 & 17 & 161 & 43 \\
\hline 5 & 2020 & 2,768 & 67 & 2,740 & 4 & - & 95 & 2,740 & 4 & - & - \\
\hline 5 & 2050 & 2,668 & 81 & 2,635 & 12 & 105 & 84 & 2,647 & 10 & 93 & 13 \\
\hline 5 & 2080 & 2,557 & 106 & 2,520 & 21 & 220 & 77 & 2,549 & 18 & 191 & 29 \\
\hline 6 & 2020 & 2,768 & 68 & 2,736 & 3 & - & 95 & 2,736 & 3 & - & - \\
\hline 6 & 2050 & 2,673 & 83 & 2,639 & 10 & 97 & 85 & 2,654 & 9 & 82 & 15 \\
\hline 6 & 2080 & 2,562 & 109 & 2,523 & 20 & 212 & 78 & 2,555 & 17 & 180 & 32 \\
\hline 7 & 2020 & 2,766 & 64 & 2,741 & 4 & - & 94 & 2,741 & 4 & - & - \\
\hline 7 & 2050 & 2,642 & 68 & 2,613 & 13 & 128 & 82 & 2,621 & 12 & 120 & 8 \\
\hline 7 & 2080 & 2,532 & 93 & 2,500 & 22 & 241 & 76 & 2,523 & 19 & 218 & 23 \\
\hline 8 & 2020 & 2,753 & 65 & 2,720 & 4 & - & 94 & 2,720 & 4 & - & - \\
\hline 8 & 2050 & 2,662 & 80 & 2,629 & 10 & 92 & 85 & 2,650 & 8 & 71 & 21 \\
\hline 8 & 2080 & 2,551 & 108 & 2,512 & 19 & 208 & 77 & 2,552 & 17 & 169 & 39 \\
\hline 9 & 2020 & 2,748 & 64 & 2,718 & 4 & - & 95 & 2,718 & 4 & - & - \\
\hline 9 & 2050 & 2,661 & 80 & 2,629 & 10 & 89 & 85 & 2,652 & 8 & 66 & 23 \\
\hline 9 & 2080 & 2,548 & 108 & 2,512 & 19 & 206 & 77 & 2,554 & 17 & 164 & 42 \\
\hline 10 & 2020 & 2,756 & 64 & 2,723 & 4 & - & 93 & 2,723 & 4 & - & - \\
\hline 10 & 2050 & 2,665 & 81 & 2,631 & 10 & 92 & 84 & 2,650 & 9 & 73 & 19 \\
\hline 10 & 2080 & 2,553 & 108 & 2,515 & 20 & 208 & 77 & 2,552 & 17 & 172 & 37 \\
\hline 11 & 2020 & 2,753 & 64 & 2,721 & 4 & - & 93 & 2,721 & 4 & - & - \\
\hline 11 & 2050 & 2,667 & 81 & 2,633 & 10 & 88 & 85 & 2,653 & 8 & 69 & 20 \\
\hline 11 & 2080 & 2,556 & 108 & 2,517 & 19 & 205 & 78 & 2,554 & 17 & 167 & 38 \\
\hline 12 & 2020 & 2,421 & 104 & 2,492 & 6 & - & 96 & 2,492 & 6 & - & - \\
\hline 12 & 2050 & 2,298 & 105 & 2,369 & 19 & 123 & 86 & 2,369 & 19 & 123 & 0 \\
\hline 12 & 2080 & 2,169 & 115 & 2,230 & 37 & 262 & 75 & 2,230 & 37 & 262 & 0 \\
\hline 13 & 2020 & 2,442 & 106 & 2,509 & 6 & - & 96 & 2,509 & 6 & - & - \\
\hline 13 & 2050 & 2,332 & 109 & 2,396 & 16 & 113 & 87 & 2,396 & 16 & 113 & 0 \\
\hline 13 & 2080 & 2,207 & 119 & 2,258 & 34 & 250 & 74 & 2,258 & 34 & 250 & 0 \\
\hline 14 & 2020 & 2,432 & 104 & 2,500 & 6 & - & 96 & 2,500 & 6 & - & - \\
\hline 14 & 2050 & 2,319 & 106 & 2,369 & 22 & 131 & 83 & 2,369 & 22 & 131 & 0 \\
\hline 14 & 2080 & 2,196 & 115 & 2,230 & 39 & 270 & 71 & 2,230 & 39 & 270 & 0 \\
\hline 15 & 2020 & 2,432 & 105 & 2,500 & 5 & - & 97 & 2,500 & 5 & - & - \\
\hline 15 & 2050 & 2,317 & 107 & 2,377 & 19 & 122 & 85 & 2,377 & 19 & 122 & 0 \\
\hline 15 & 2080 & 2,193 & 117 & 2,239 & 37 & 260 & 73 & 2,239 & 37 & 260 & 0 \\
\hline
\end{tabular}


Table 1.1.-Continued

\begin{tabular}{|c|c|c|c|c|c|c|c|c|c|c|c|}
\hline \multirow{3}{*}{$\begin{array}{c}\text { Map ID } \\
\text { (figure 20) }\end{array}$} & \multirow{3}{*}{ Year } & \multicolumn{6}{|c|}{ Future withdrawal scenario } & \multirow{2}{*}{\multicolumn{3}{|c|}{$\begin{array}{c}\text { Future withdrawal scenario + } \\
\text { enhanced infiltration scenario } \\
\text { Posterior }\end{array}$}} & \multirow{3}{*}{$\begin{array}{c}\text { Difference } \\
\text { in declines } \\
\text { from } 2020 \\
\text { levels (ft) }\end{array}$} \\
\hline & & \multicolumn{2}{|c|}{ Prior } & \multicolumn{4}{|c|}{ Posterior } & & & & \\
\hline & & $\begin{array}{c}\text { Mean } \\
\text { elevation } \\
\text { (ft) }\end{array}$ & $\begin{array}{l}\text { St. } \\
\text { dev. } \\
\text { (ft) }\end{array}$ & $\begin{array}{c}\text { Mean } \\
\text { elevation } \\
\text { (ft) }\end{array}$ & $\begin{array}{l}\text { St. } \\
\text { dev. } \\
\text { (ft) }\end{array}$ & $\begin{array}{l}\text { Decline } \\
\text { from } 2020 \\
\text { levels }(\mathrm{ft})\end{array}$ & $\begin{array}{l}\text { Uncertainty } \\
\text { reduction } \\
(\%)\end{array}$ & $\begin{array}{c}\text { Mean } \\
\text { elevation } \\
\text { (ft) }\end{array}$ & $\begin{array}{l}\text { St. } \\
\text { dev. } \\
\text { (ft) }\end{array}$ & $\begin{array}{l}\text { Decline } \\
\text { from } 2020 \\
\text { levels (ft) }\end{array}$ & \\
\hline 16 & 2020 & 2,430 & 103 & 2,498 & 6 & - & 96 & 2,498 & 6 & - & - \\
\hline 16 & 2050 & 2,310 & 104 & 2,349 & 25 & 148 & 79 & 2,349 & 25 & 148 & 0 \\
\hline 16 & 2080 & 2,189 & 113 & 2,210 & 41 & 287 & 68 & 2,210 & 41 & 287 & 0 \\
\hline 17 & 2020 & 2,424 & 102 & 2,491 & 7 & - & 95 & 2,491 & 7 & - & - \\
\hline 17 & 2050 & 2,286 & 101 & 2,313 & 30 & 178 & 74 & 2,313 & 30 & 178 & 0 \\
\hline 17 & 2080 & 2,166 & 110 & 2,174 & 46 & 317 & 65 & 2,174 & 46 & 317 & 0 \\
\hline 18 & 2020 & 2,419 & 100 & 2,483 & 8 & - & 93 & 2,483 & 8 & - & - \\
\hline 18 & 2050 & 2,273 & 98 & 2,288 & 34 & 195 & 69 & 2,288 & 34 & 195 & 0 \\
\hline 18 & 2080 & 2,154 & 107 & 2,150 & 48 & 333 & 59 & 2,150 & 48 & 333 & 0 \\
\hline 19 & 2020 & 2,425 & 101 & 2,491 & 7 & - & 95 & 2,491 & 7 & - & - \\
\hline 19 & 2050 & 2,295 & 102 & 2,320 & 31 & 171 & 75 & 2,320 & 31 & 171 & 0 \\
\hline 19 & 2080 & 2,178 & 111 & 2,185 & 47 & 307 & 66 & 2,185 & 47 & 307 & 0 \\
\hline 20 & 2020 & 2,415 & 99 & 2,463 & 9 & - & 93 & 2,463 & 9 & - & - \\
\hline 20 & 2050 & 2,329 & 101 & 2,391 & 21 & 73 & 84 & 2,391 & 21 & 73 & 0 \\
\hline 20 & 2080 & 2,221 & 110 & 2,280 & 39 & 184 & 73 & 2,280 & 39 & 184 & 0 \\
\hline 21 & 2020 & 2,400 & 97 & 2,413 & 9 & - & 92 & 2,413 & 9 & - & - \\
\hline 21 & 2050 & 2,310 & 98 & 2,323 & 19 & 90 & 81 & 2,323 & 19 & 90 & 0 \\
\hline 21 & 2080 & 2,209 & 105 & 2,228 & 35 & 185 & 72 & 2,228 & 35 & 185 & 0 \\
\hline 22 & 2020 & 2,766 & 52 & 2,750 & 7 & - & 89 & 2,750 & 7 & - & - \\
\hline 22 & 2050 & 2,702 & 69 & 2,689 & 29 & 61 & 58 & 2,692 & 27 & 59 & 3 \\
\hline 22 & 2080 & 2,640 & 68 & 2,619 & 40 & 131 & 50 & 2,624 & 40 & 126 & 5 \\
\hline 23 & 2020 & 2,588 & 76 & 2,628 & 14 & - & 84 & 2,628 & 14 & - & - \\
\hline 23 & 2050 & 2,521 & 11 & 2,519 & 0 & 109 & 100 & 2,519 & 0 & 109 & - \\
\hline 23 & 2080 & 2,519 & 0 & 2,519 & 0 & 109 & 13 & 2,519 & 0 & 109 & - \\
\hline 24 & 2020 & 2,484 & 115 & 2,549 & 10 & - & 93 & 2,549 & 10 & - & - \\
\hline 24 & 2050 & 2,308 & 108 & 2,371 & 19 & 178 & 87 & 2,371 & 19 & 178 & 0 \\
\hline 24 & 2080 & 2,161 & 119 & 2,221 & 34 & 328 & 77 & 2,221 & 34 & 328 & 0 \\
\hline 25 & 2020 & 2,437 & 108 & 2,503 & 6 & - & 96 & 2,503 & 6 & - & - \\
\hline 25 & 2050 & 2,306 & 105 & 2,373 & 16 & 130 & 87 & 2,373 & 16 & 130 & 0 \\
\hline 25 & 2080 & 2,176 & 114 & 2,233 & 35 & 270 & 75 & 2,233 & 35 & 270 & 0 \\
\hline 26 & 2020 & 2,455 & 109 & 2,524 & 8 & - & 93 & 2,524 & 8 & - & - \\
\hline 26 & 2050 & 2,361 & 115 & 2,430 & 19 & 94 & 84 & 2,430 & 19 & 94 & 0 \\
\hline 26 & 2080 & 2,239 & 127 & 2,296 & 35 & 228 & 73 & 2,296 & 35 & 228 & 0 \\
\hline 27 & 2020 & 2,358 & 97 & 2,352 & 6 & - & 96 & 2,352 & 6 & - & - \\
\hline 27 & 2050 & 2,302 & 96 & 2,304 & 12 & 48 & 88 & 2,304 & 12 & 48 & 0 \\
\hline 27 & 2080 & 2,220 & 101 & 2,238 & 25 & 114 & 78 & 2,238 & 25 & 114 & 0 \\
\hline 28 & 2020 & 2,447 & 109 & 2,505 & 7 & - & 96 & 2,505 & 7 & - & - \\
\hline 28 & 2050 & 2,315 & 76 & 2,355 & 16 & 150 & 84 & 2,355 & 16 & 150 & 0 \\
\hline 28 & 2080 & 2,263 & 32 & 2,249 & 11 & 256 & 72 & 2,249 & 11 & 256 & 0 \\
\hline 29 & 2020 & 2,348 & 95 & 2,340 & 9 & - & 92 & 2,340 & 9 & - & - \\
\hline 29 & 2050 & 2,295 & 95 & 2,296 & 13 & 44 & 88 & 2,296 & 13 & 44 & - \\
\hline 29 & 2080 & 2,217 & 100 & 2,232 & 25 & 107 & 78 & 2,232 & 25 & 107 & 0 \\
\hline
\end{tabular}




\section{Appendix 2. Parameter Estimation and Uncertainty Analysis of HVHM with PESTPP-IES}

Parameter estimation and uncertainty analysis of Hualapai Valley Hydrologic Model (HVHM) was performed using PESTPP-SWP and PESTPP-IES components of the PEST++ software suite (White and others, 2020). Pre- and postprocessing were performed using python packages FloPy (Bakker and others, 2016) and PyEMU (White, 2016). All software packages used in this analysis are free and open source. Software executable files, input files, and helper scripts used to produce the results of this report are available in a supplementary data release (Knight, 2021).

\section{Workflow Summary}

The following are an outline of the workflow and a description of the most important choices of software options that lead to the results presented in this report.

1. Develop a prior parameter distribution.

2. Parameterize model inputs.

3. Build and run a prior ensemble of models containing parameter values drawn from the prior parameter distribution.

4. Condition prior ensemble of models on the basis of evaluation of model results.

5. Starting with the conditioned prior ensemble, employ an iterative algorithm that evaluates model fit to historical observations to develop an updated ("calibrated") posterior model distribution.

6. Condition the posterior ensemble of models on the basis of evaluation of model fit and reasonableness of parameter values.

7. Use conditioned posterior ensemble of models to simulate future withdrawal and enhanced recharge scenarios.

\section{Prior Parameter Distribution}

Uncertainties in model parameters and outputs are presented using a Bayesian uncertainty framework (Fienen and others, 2013). This requires definition of a prior parameter distribution that is based on expert knowledge and previous modeling results. The prior parameter distribution includes a mean value and variance for every adjustable model parameter. The prior parameter distribution for HVHM is defined using a truncated, multivariate (log-)Gaussian distribution. Mean values for every parameter in the prior parameter distribution were obtained through manual trial and error. The forward model was run many times by varying a small number of base property values, and using combinations of base property values, deemed reasonable and within the range of previous estimates. Model outputs were evaluated and compared to understand model behavior and sensitivities. Exponential variograms specify the correlation between spatially distributed parameters with a range of $5000 \mathrm{~m}$ for grid scale parameters and a range of $12,500 \mathrm{~m}$ for pilot-point scale parameters.

History matching of transient groundwater-level observations is used to update the mean value and variance of the adjustable parameters, which results in a posterior parameter distribution. The posterior model ensemble comprises models built with parameters drawn from this posterior parameter distribution. The model realizations of the posterior ensemble are used to produce the scenario forecast results in this report.

\section{Model Parameterization}

The python package PyEMU was used to build a PEST++ control file, and associated template and control files serve as an interface to parameterize almost all model inputs. HVHM adjustable parameters are strictly multipliers that modify the underlying original model property values, which were established through trial-and-error methods described earlier. The mean for every multiplier parameter is 1.0 . The upper and lower limits of these multiplier parameters imply the uncertainty of the underlying original model property values at different spatial or temporal scales.

PyEMU was also used to define the prior parameter distribution and build a prior model ensemble by drawing parameter values from the distribution. A large number of model realizations $(n=300)$ was drawn from the prior parameter distribution according to the defined mean and covariance of the parameters.

\section{Evaluation and Conditioning of Prior Model Ensemble}

The prior model ensemble realizations were run in parallel using PESTPP-SWP and outputs were compared to historical observations. The combined ensemble results were expected to bracket all important observations and potential outcomes using feasible, even if occasionally extreme, values and combinations of parameters. Of the initial 300 realizations in the prior parameter ensemble, the 100 realizations yielding the best fit to the important historical observations were retained for conditioning with PESTPP-IES. 


\section{Estimation and Conditioning of Posterior Model Ensemble}

PESTPP-IES (White, 2018) implements a form of the iterative ensemble smoother (IES) algorithm (Chen and Oliver, 2013), which minimizes a least-squares objective function in high dimensions. It accomplishes this in a manner similar to the GaussLevenburg-Marquardt (GLM) algorithm, but instead of filling a complete Jacobian matrix representing the first-order relation between every adjustable parameter and every observation, IES empirically estimates the Jacobian matrix through Monte Carlo ensemble simulation.

The IES algorithm substantially reduces the computational demand for highly parameterized models compared to GLM. In each iteration of the GLM algorithm, the forward model must be run at least once for each adjustable parameter. IES approximates the Jacobian matrix using a specified number of realizations, so the number of model runs required in each iteration of the parameter estimation process can be far fewer than the number of adjustable parameters. HVHM includes 75,586 adjustable parameters, but only 100 realizations are used to empirically estimate the Jacobian matrix.

A potential downside of using an ensemble with fewer model runs than the number of parameters is the potential for substantial error in estimated cross covariance between each parameter and observation, which can lead to spurious correlation. This is addressed through an approach called localization, which injects expert knowledge or obvious physical limitations on the magnitude of correlation between specific parameters and observations. PESTPP-IES includes an option to automate this approach, called automatic adaptive localization. Automatic adaptive localization compares the empirical correlation coefficient between each parameter and observation to a background level of correlation calculated by repeated circular shifting of the observation vector relative to the parameter vector. Correlations greater than 1 standard deviation from the mean background correlation are deemed statistically significant and retained. The remainder of the correlations are set to zero (White and others, 2020).

The use of ensembles in the IES algorithm provides the benefit of built-in uncertainty analysis. Instead of upgrading a single set of parameters based on a single set of residuals (simulated minus observed), IES adjusts an ensemble of parameters based on an ensemble of residuals. The spread of these ensembles provides an empirical estimation of the uncertainty associated with each parameter value. Forecasts of interest, like future groundwater levels, are included as zero-weighted observations so that ensemble results include a range of future conditions based on the parameter variance.

The parameter estimation process implemented in IES frequently narrows the distribution of parameters drawn from the prior parameter ensemble to ranges that best replicate historical observations. The parameter estimation process begins with a wide prior distribution to avoid prior data conflict, the condition of a nonzero weighted observation falling outside the range of simulated equivalents produced by the ensemble of models. As implemented here, IES drops prior data conflicts by assigning a zero weight to observations falling outside the range of simulated equivalents before the first upgrade iteration. Attempting to match such observations would require model realizations comprising extreme parameter values or unreasonable combinations of parameters compared to realizations producing outputs that bracket the remainder of the (nonconflicted) observations.

PESTPP-IES produces an ensemble of model results in each iteration of the algorithm with typically lower objective function values as it seeks to minimize the least squares function. Occasionally a model realization will produce an outlier result with an objective function much greater than the mean of the remaining realizations. For HVHM the bad_phi sigma option was set to 2.0, which drops model realizations producing objective functions greater than the current mean objective function plus 2 times the objective function standard deviation of the ensemble. This helps focus the parameter estimation process by rejecting realizations unlikely to produce a good fit.

The posterior model ensemble estimated by PESTPP-IES was conditioned to include only the 40 model realizations that best match important observations without resorting to extreme or unrealistic distributions of parameters.

\section{Execution and Evaluation of Scenario Forecasts}

HVHM scenario simulations were run in parallel using each model realization included in the conditioned posterior model ensemble. Forecasted groundwater levels at times and locations of interest were characterized with basic summary statistics: maximum, minimum, mean, and standard deviation. Reduction of uncertainty gained from the parameter estimation process was calculated for each forecast as the percent reduction in standard deviations produced from the prior to the posterior model ensemble. 


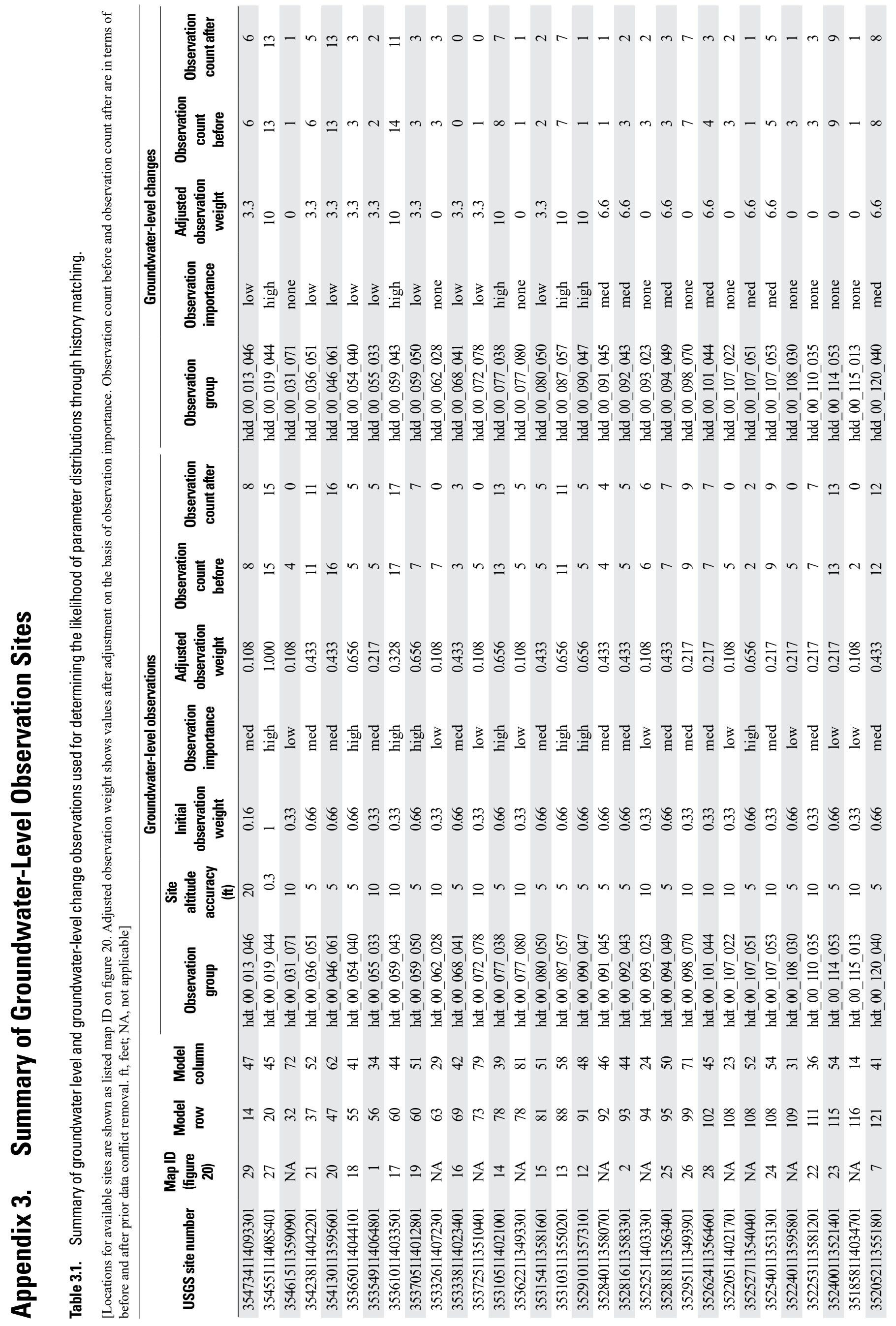




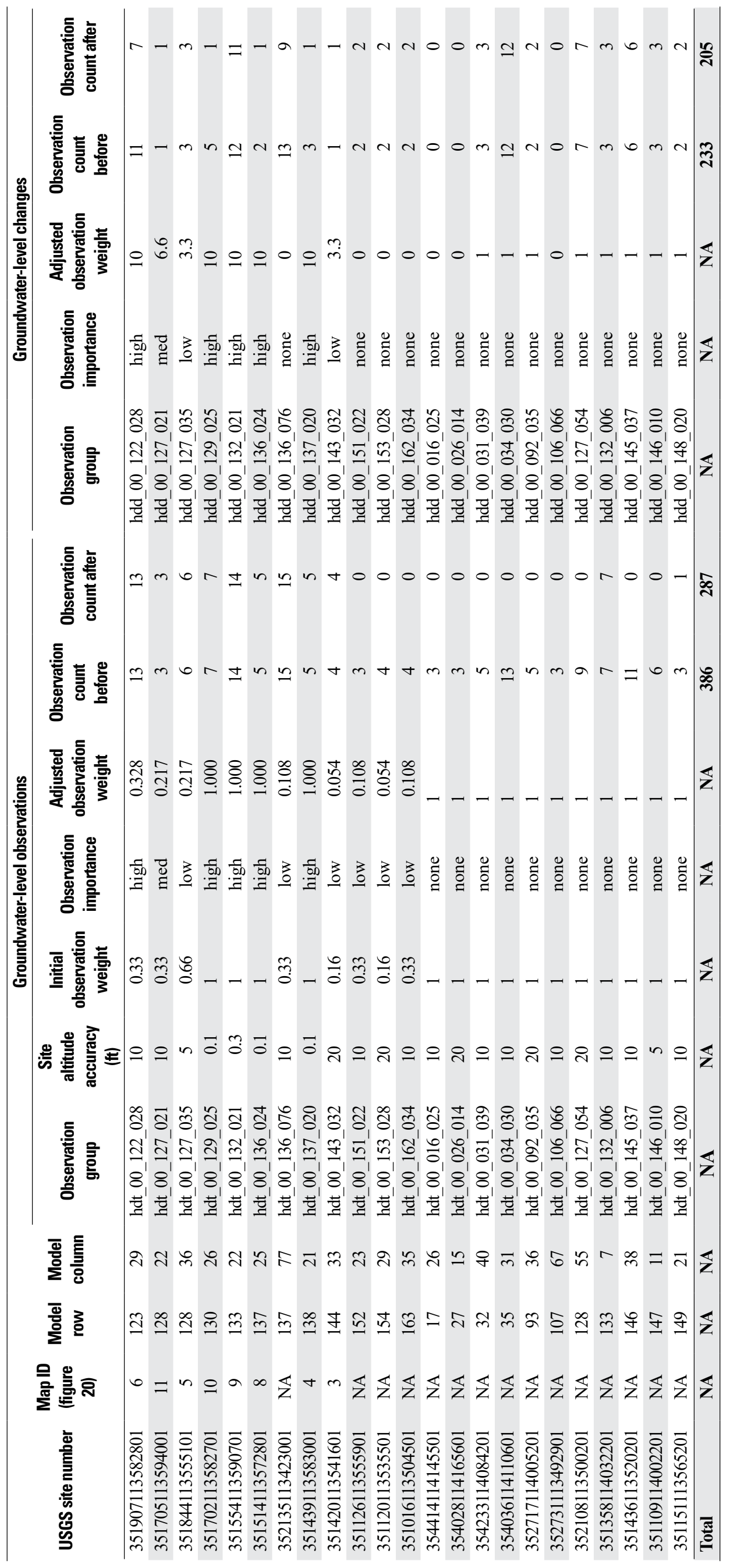



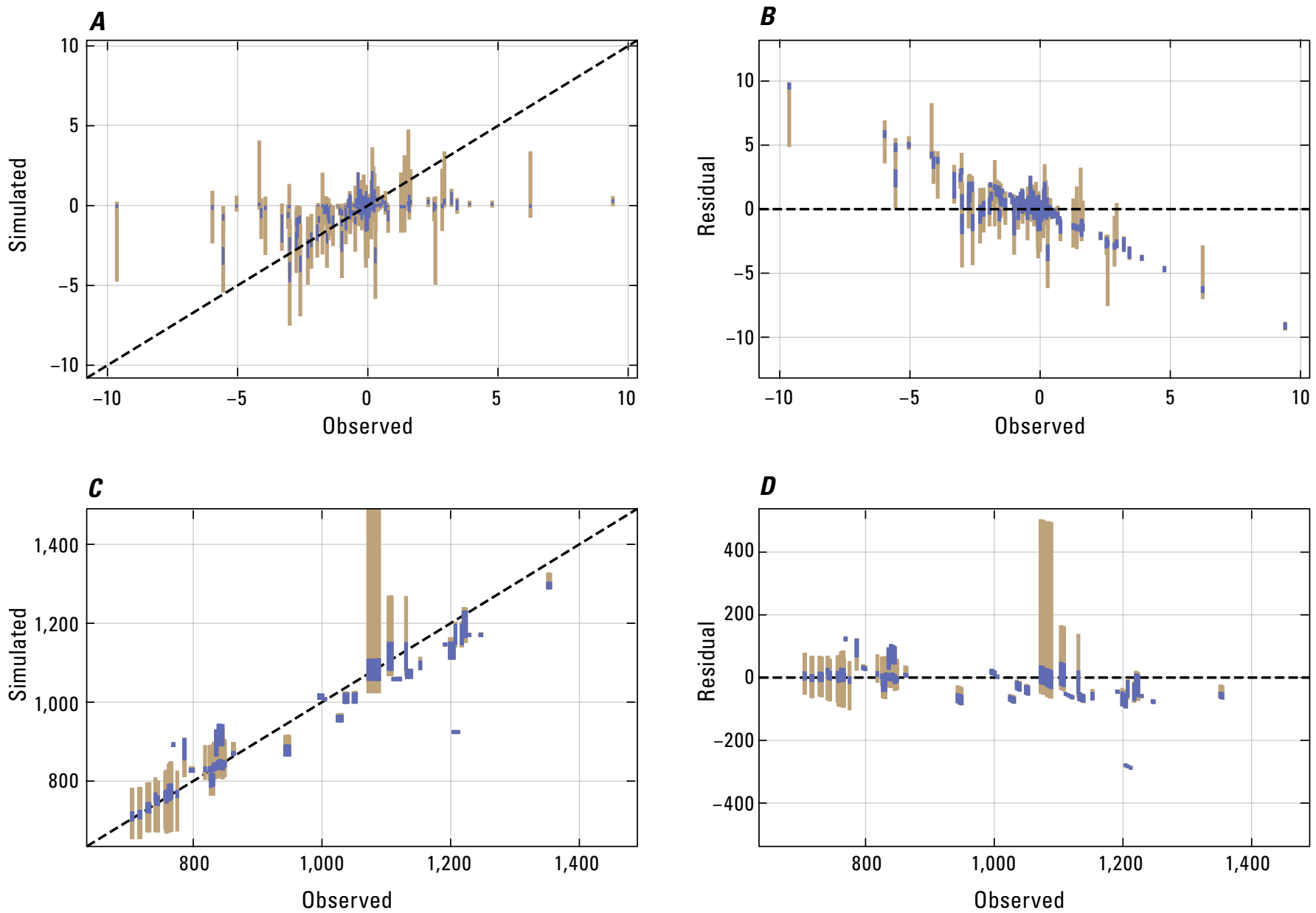

Figure 3.1. One-to-one plots comparing observed to simulated values, and observed to simulated residual values, organized by observation type. $A$, Graph comparing the observed (233 observations) to the simulated temporal difference of groundwater level. $B$, Graph comparing the observed (233 observation) to simulated residual temporal difference of groundwater level. $C$, Graph comparing the observed (386 observations) and simulated transient groundwater level. $D$, Graph comparing the observed (386 observations) and simulated residual transient groundwater level. Tan bars represent model results from the prior ensemble. Blue bars represent model results from the posterior ensemble. Dashed lines represent 1:1 relation between observations and simulated equivalents. 
Moffett Field Publishing Service Center Manuscript approved July 23, 2021

Edited by Phil Frederick

Illustration support by JoJo Mangano Layout and design by Cory Hurd 


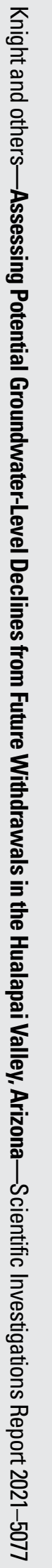

